\begin{abstract}
UNIVERSIDADE DE SÃO PAULO
PROGRAMA DE PÓS-GRADUAÇÃO STRICTO SENSU INTERUNIDADES EM ESTÉTICA E HISTÓRIA DA ARTE PGEHA/USP
\end{abstract}

SABRINA POPP MARIN

\title{
COMUNICAÇÃO VIRTUAL DE MUSEUS: A informação sobre Arte nos sites da TATE $e$ do MAC
}

Orientadora: Profa. Dra. Lisbeth Ruth Rebollo Gonçalves 


\section{COMUNICAÇÃO VIRTUAL DE MUSEUS: A informação sobre Arte nos sites da TATE e do MAC}

Dissertação apresentada ao Programa de PósGraduação stricto sensu Interunidades em Estética e História da Arte PGEHA/USP (Universidade de São Paulo) para obtenção do título de Mestre. Área de concentração: Teoria e Crítica de Arte Orientadora:Profa. Dra. Lisbeth Ruth Rebollo Gonçalves. 


\section{FOLHA DE APROVAÇÃO}

\section{Sabrina Popp Marin}

Comunicação Virtual de Museus: a informação sobre Arte nos sites da TATE e do MAC

Dissertação apresentada ao Programa de PósGraduação stricto sensu Interunidades em Estética e História da Arte PGEHA/USP (Universidade de São Paulo) para obtenção do título de Mestre. Área de concentração: Teoria e Crítica de Arte

Aprovado em: l I

Prof. Dr.

Instituição: Assinatura:

Prof. Dr.

Instituição: Assinatura:

Prof. Dr. 


\section{AGRADECIMENTOS}

Agradeço à professora Lisbeth Rebollo Gonçalves pelas orientações, contribuições e sugestões dadas ao longo deste processo de pesquisa.

Aos profissionais do MAC USP e, em especial, ao jornalista Sérgio Miranda pela paciência, disponibilidade e contribuições.

A todos os professores com os quais tive contato por meio das aulas, palestras e demais atividades da Pós-Graduação; pelas contribuições, diretas e indiretas, à pesquisa.

Aos meus colegas de curso, com quem dividi dúvidas, sugestões, incertezas e determinação para continuar.

Às professoras Daisy Peccinini e Claudia Fazzolari pelas críticas, comentários e sugestões fundamentais para o rumo deste estudo.

À minha família, em especial aos meus pais e avós pela base fornecida ao longo desses anos.

Ao meu companheiro Douglas, pelas ideias, contribuições e inquietações, e pelo estímulo constante ao estudo.

Aos amigos e colegas de trabalho pelo carinho, ajuda e compreensão.

A todos, muito obrigada. 
"O pensamento não é um meio de conhecer, mas de designar os fatos, de ordená-los, de fazê-los manuseáveis: isto é o que pensamos hoje acerca do pensamento; amanhã talvez pensemos diferente.

De onde provém o sentimento da verdade?

Em primeiro lugar: não tememos discrepar de nós mesmos; em segundo lugar: aumenta nosso sentimento de força, também contra nós mesmos."1

Friedrich Nietzsche

\footnotetext{
${ }^{1}$ NIETZSCHE, Friedrich. Vontade de Potência. São Paulo: Vozes, 2011. p. 49.
} 


\section{RESUMO}

MARIN, Sabrina Popp. Comunicação Virtual de Museus: a informação sobre Arte nos sites da TATE e do MAC. Dissertação (mestrado) - Programa de Pós-Graduação Interunidades em Estética e História da Arte da Universidade de São Paulo - PGEHA/USP, São Paulo, 2011.

Esta pesquisa investiga como os sites de duas instituições museológicas ocupam o Ciberespaço. Objetiva identificar aproximações e distanciamentos entre elas, no que diz respeito à qualidade da informação comunicada e ao entendimento do espaço virtual, enquanto local em potencial para a construção do discurso simbólico sobre Artes. Preocupase igualmente em observar a efetivação do papel do Museu como agente de aproximação e integração entre a sociedade e as demandas geradas pelas novas tecnologias.

O Ciberespaço institui um novo tipo de espectador/internauta que se relaciona com os bens culturais de maneira contrária à já sacralizada pelas instituições museológicas surgidas nos séculos passados.

A análise dos espaços do MAC Virtual, no Brasil, e da TATE Online, na Inglaterra, mostrou que o projeto virtual terá mais sucesso à medida que evita recriar, no ambiente virtual, o espaço consagrado para a exibição da obra de arte.

Palavras-chave: Internet; Ciberespaço; Site; Museu; Comunicação; Arte. 


\section{ABSTRACT}

MARIN, Sabrina Popp. Museum's Virtual Communication: The information about Arts at the TATE's and MAC's websites. Dissertation (masters) - Programa de Pós-Graduação Interunidades em Estética e História da Arte da Univerisdade de São Paulo - PGEHA/USP, São Paulo, 2011.

This research investigates how the websites of two museological institutions occupy the Cyberspace. Its main goal is of identifying approaches and differences between them regarding the quality of published information and the understanding of the virtual space while place in potential for the development of the symbolic speech about Arts. At the same time it focuses on the consolidation of the Museum's role as integration agent between society and the demands generated by new technologies.

The Cyberspace creates a new kind of spectator/user that relates itself with the cultural assets in an opposite way to the traditional manner of the museological institutions that were created in the last centuries.

Analyzing the website MAC Virtual in Brazil and TATE Online in England, showed that the virtual project will be more successful if it avoids recreating, in the virtual space, the traditional space for displaying the Artworks.

Keywords: Internet; Cyberspace; Site; Museum; Communication; Art. 


\section{SUMÁRIO}

INTRODUÇÃO

\section{CAPÍTULO 1}

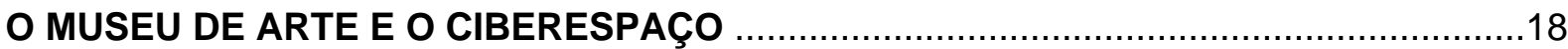

1.1 O surgimento da Internet: a Arte e o espaço virtual ..............................................19

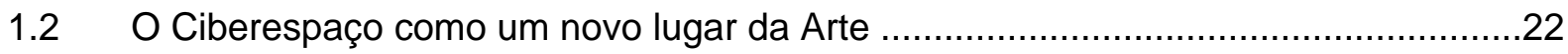

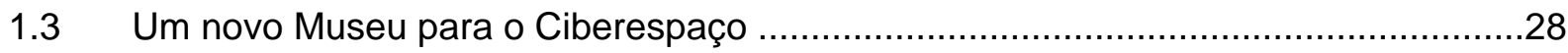

\section{CAPÍTULO 2}

OS SITES DE MUSEU E A FORMAÇÃO DO PÚBLICO - APRECIAÇÃO SOBRE A TATE E

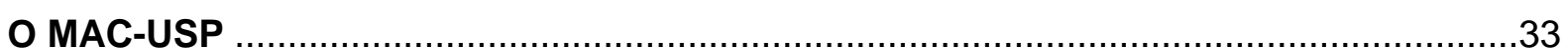

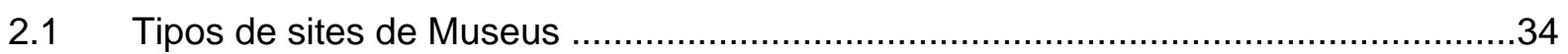

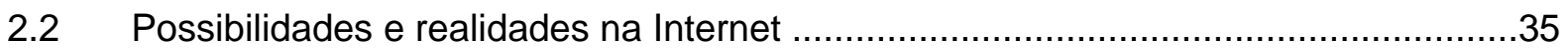

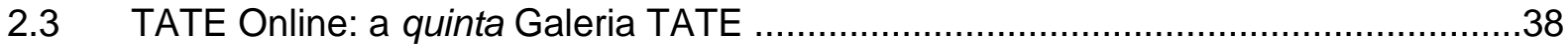

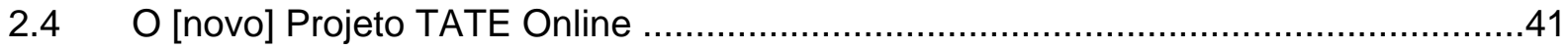

2.4.1 Princípios para o desenvolvimento da plataforma TATE Online .............................43

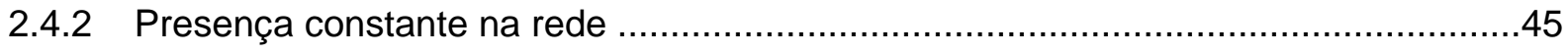

2.5 Estratégias de comunicação e aproximação com o usuário ....................................47

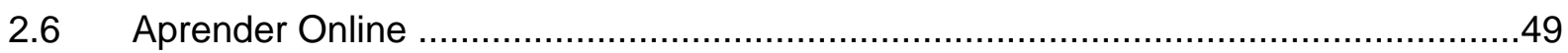

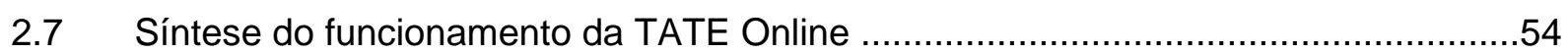

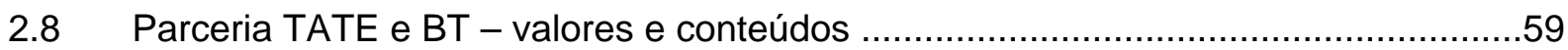

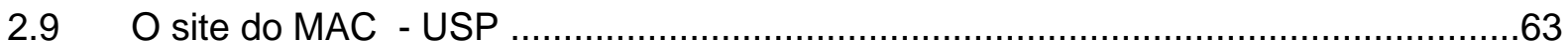

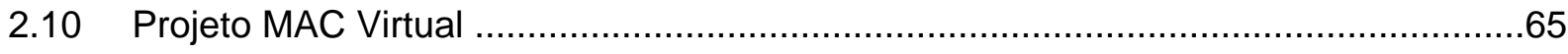

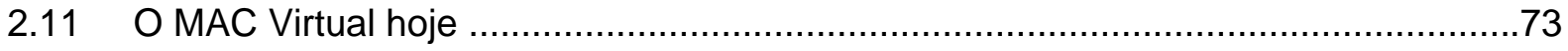

2.12 TATE e MAC: Experiências virtuais distantes .................................................. 75

\section{CAPÍTULO 3}

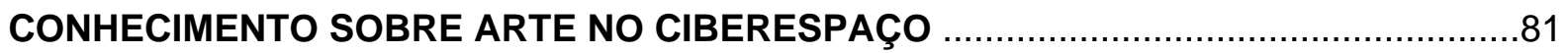

3.1 TATEETC. e Contemporânea: espaços para o debate sobre Arte além dos sites .....82

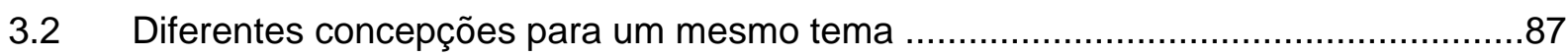

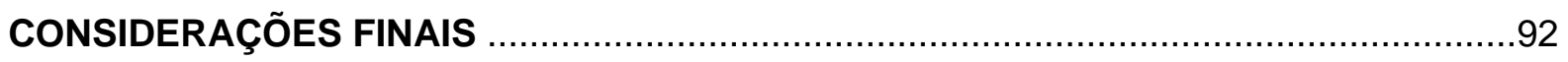


REFERÊNCIAS BIBLIOGRÁFICAS

.96

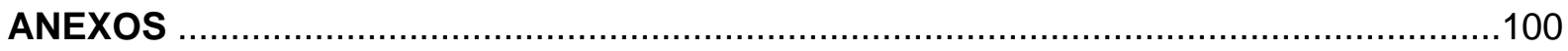

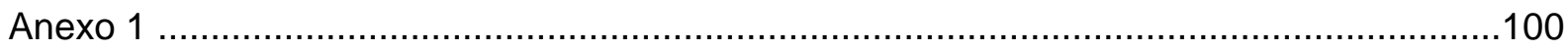

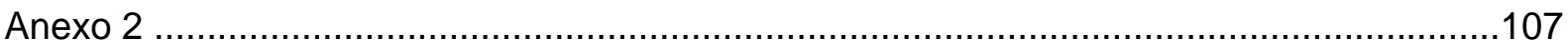

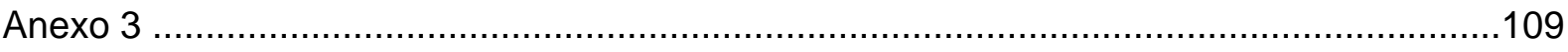




\section{LISTA DE IMAGENS}

Imagem 1 - Detalhe da página Explore Tate Britain

Imagem 2 - Detalhe da página TATE Intermedia Art

Imagem 3 - Detalhe da página TATE Kids

Imagem 4 - Detalhe da página Young TATE

Imagem 5 - Detalhe da página TATE Schools and Teachers

Imagem 6 - Detalhe da página TATE Learn Online

Imagem 7 - Detalhe da página TATE Papers

Imagem 8 - Detalhe do Portal TATE Online

Imagem 9 - Página com agenda das exposições em cartaz nas quatro galerias

Imagem 10 - Detalhe da página inicial do MAC Virtual

Imagem 11 - Detalhe da página com acesso ao banco de dados do acervo

Imagem 12 - Detalhe da página com informações sobre as exposições

Imagem 13 - Detalhe da página Arte do Século XX / XXI - Visitando o MAC na Web

Imagem 14 - Detalhe da página com informações sobre a biblioteca

Imagem 15 - Detalhe da página Museu Experimental

Imagem 16 - Detalhe da página Museu Lúdico

Imagem 17 - Detalhe da página atual de acesso ao portal MAC Virtual

Imagem 18 - Gráfico representando acessos entre 1998 e 2009

Imagem 19 - Detalhe da matéria "Arte Contemporânea e crítica de arte", disponível na revista digital Contemporânea

Imagem 20 - Detalhe da página inicial da revista Contemporânea

Imagem 21 - Detalhe da página inicial do número 22 da TATEETC.

Imagem 22 - Detalhe da página da TATEETC. com destaque para o contexto em que o assunto tratado aparece no acervo TATE

Imagem 23 - Detalhe do conteúdo exclusivo disponibilizado apenas na versão online da revista TATEETC. 


\section{ABREVIAÇÕES}

Bienal Mercosul - Fundação Bienal do Mercosul.

Bienal SP - Fundação Bienal de São Paulo.

BT - British Telecon.

MAC USP - Museu de Arte Contemporânea da USP.

MAC Virtual - site do MAC USP.

Malba - Museu de Arte Latino-americano de Buenos Aires.

MAM SP - Museu de Arte Moderna de São Paulo.

MoMA - Museu de Arte Moderna, em Nova lorque.

MUVA - Museu Virtual de Artes El País, no Uruguai.

POLI - Escola Politécnica da Universidade de São Paulo.

SFMOMA - Museu de Arte Moderna, em São Francisco.

TATE Online - site da TATE.

USP - Universidade de São Paulo. 


\section{GLOSSÁRIO}

Blog — Site na Internet que permite a atualização rápida de conteúdos feita por um ou mais de um usuário.

Ciberespaço - É o espaço de comunicação gerado pela interconexão da rede mundial dos computadores, a Internet.

Hiperlink - Ligação que permite o acesso e o direcionamento via Internet a outros dados e conteúdos presentes nos sites.

Hipertexto - É um texto em formato digital onde há recursos para acessar outros textos, imagens ou citações na Internet.

Interface - Meio de interação entre o usuário e os recursos disponíveis nos sistemas de informação do computador.

Internet - Conjunto de redes regionais que a partir de conexões entre si e de protocolos de comunicação comuns, permite que dados sejam trocados e trafeguem em uma escala mundial.

Podcasting - Arquivos de som, imagem e vídeo que são armazenados na Internet e que permitem aos usuários acompanhar constantemente sua atualização.

Portal - Página inicial de acesso ao site do museu. Nela, o visitante encontra informações principais e também pode se dirigir às demais áreas do site.

Site - É o lugar, o endereço de determinada página na Internet.

w.w.w. - Sistema de informações direcionado a agrupar todos os outros sistemas de informação disponíveis na Internet, padronizando e eliminando fronteiras por meio de uma interface comum a todos que acessam dados na rede. 


\title{
INTRODUÇÃO
}

A emergência da Internet como um espaço em potencial da era da comunicação em que estamos inseridos nos faz pensar em uma nova dinâmica na mediação dos museus com a sociedade.

Desde a Revolução Industrial, as transformações tecnológicas impactam na sociedade e nos bens de produção, acelerando também os mecanismos que regulam e legitimam as produções culturais.

Os museus, que tiveram sua origem no século XVII, depois da experiência dos Gabinetes de Curiosidades ${ }^{2}$, tem estreita relação com a ideia de modernidade ligada às conquistas da classe burguesa. A ideia de museu de arte está apoiada na necessidade de conceituar, proteger e exibir um conjunto de obras que se acredita representativo de determinada época, retirando-o de circulação do contexto cotidiano e incluindo-o no espaço institucionalizado.

Hoje, a noção de museu enquanto espaço desligado do tempo das coisas atuais, lugar atemporal em que se recolhem objetos eleitos enquanto representantes iconográficos e de pensamentos de certas sociedades, está modificada.

Cada vez mais os museus de arte configuram-se como verdadeiros centros culturais, promovendo ações que extrapolam os limites das próprias coleções que abrigam, elevando a obra de arte ao patamar publicitário e a experiência estética ao nível do entretenimento.

Nesse sentido, Ricardo Basbaum comenta ${ }^{3}$ :

\begin{abstract}
"Se tivermos em conta a tradição moderna do artista que marca fortemente sua diferença em relação à sociedade e ao senso comum - ou seja, busca alguma forma de problematização ou interferência no estado corrente das coisas - então o atual momento institucional da arte deve ser foco de intensa investigação, pois também o tecido institucional detém os mesmos processos de saber e os gerencia ao seu modo, construindo alguma imagem de artista que integre interferência, diferença e transgressão, ainda que (claro) nos limites de seu próprio gerenciamento".
\end{abstract}

Os processos que integram a produção do discurso museológico são cada vez menos unidirecionais e contam com a participação de agentes como o público, o mercado de bens culturais e instituições governamentais que definem o circuito da Arte. As transformações tecnológicas, principalmente as experimentadas nos últimos 30 anos com 0 advento da Internet, podem ser elencadas como importante agente de aceleração e atualização do papel do museu na sociedade contemporânea.

\footnotetext{
${ }^{2}$ Salões surgidos a partir do século XVI destinados a abrigar as coleções de objetos de História Natural normalmente recolhidos por membros da nobreza e oriundos das expedições ao Novo Mundo.

${ }^{3}$ Disponível em http://www.forumpermanente.org/.painel/artigos/rb_museus/, acesso em setembro de 2010.
} 
No cenário da sociedade atual, o desenvolvimento da Internet é, na verdade, a exacerbação do potencial de colaboração e construção cooperativa da realidade humana. As modificações na forma do ser humano de se relacionar com as inovações tecnológicas estabelecem a forma como convivemos com nosso próprio desenvolvimento.

De acordo com Pierre Levy"

\begin{abstract}
"Aquilo que identificamos, de forma grosseira, como "novas tecnologias" recobre na verdade a atividade multiforme de grupos humanos, um devir coletivo complexo que se cristaliza sobretudo em volta de objetos materiais, de programas de computador e de dispositivos de comunicação. É o processo social em toda a sua opacidade, é a atividade dos outros, que retorna para o indivíduo sob a máscara estrangeira, inumana, da técnica."
\end{abstract}

Nesse sentido, a principal característica do Ciberespaço, sua condição de mídia colaborativa, seu potencial de alcance e de construção e conexão de grupos fisicamente distantes em torno de interesses e ideais comuns passam a ser percebidos pelas instituições culturais como possibilidades de se relacionar com o público, pensando inicialmente em como atrair novos visitantes e conservar os espectadores já frequentes.

Com as grandes possibilidades de entradas e ferramentas que a rede oferece, 0 espaço virtual foi rapidamente reconhecido como lugar de divulgação e promoção das atividades dos museus. Por volta dos anos 1990, eles passam a ocupar o espaço virtual como estratégia de marketing, de aproximação com o público e, em alguns casos, como alternativa e um ponto de acesso institucional mais democrático quando não tem potencial financeiro para realizar produções impressas e inserir sua marca no tecido cultural e no campo mercadológico.

Não só o campo das artes e da cultura, mas outros setores da sociedade ocuparamse rapidamente em habitar o espaço virtual. Essa ocupação acelerada gerou alguns problemas no que diz respeito ao perfil qualitativo das informações publicadas. Por ser um espaço aberto, de construção compartilhada e acesso livre, as entradas na rede são ilimitadas e todo e qualquer tipo de informação pode ser construído e disseminado.

O que acontece então é que, em muitos casos, precisa-se garantir a credibilidade da informação por meio de um nome, marca ou valores que encontrem sua correspondência no universo presencial.

Nesse sentido, os sites de museus e instituições culturais estão amparados pelo reconhecimento e trabalho que realizam em suas instalações.

Se as transformações ocorridas, por volta dos anos 1960, no estatuto da obra de arte e as inquietações propostas pelos artistas foram primeiramente percebidas pelos diretores e conservadores dos Museus de Arte Moderna e Contemporânea e dos Centros Culturais, e

\footnotetext{
${ }^{4}$ LÉVY, Pierre. Cibercultura. São Paulo: Ed. 34, 1999. p. 28.
} 
os Museus são instituições responsáveis por legitimar, validar e veicular novas informações e tendências ligadas à Arte; caberia a eles essa nova tarefa de pensar o Ciberespaço como um campo de atuação e possibilidades de encontros e formação de um público de arte contemporânea.

Quando se entra em um Museu e visita uma exposição, espera-se encontrar uma seleção de obras ou objetos apresentados dentro de um contexto de interpretação. A visita ao Museu pressupõe a articulação de duas categorias: tempo e espaço.

O tempo de apreciação da obra, de experiência estética e de elaboração de comparações, análises e questionamentos é diferente, uma vez que o espaço requer atenção, deslocamento e percepção da obra.

O museu da era virtual precisa enfrentar o desafio de comunicar o discurso crítico e curatorial, desvinculado da noção de tempo e espaço, que é o binômio sobre o qual se apoia a exposição de arte.

Na fase inicial dessa pesquisa, realizou-se uma verificação preliminar para identificar as instituições que dispunham de sites na Internet, e de que forma dava-se essa ocupação da rede para veicular informações sobre Arte.

O que se observou, inicialmente, é que a maioria dos sites pesquisados não levava em conta o potencial que a própria mídia oferece como possibilidade de participação do internauta: fóruns de discussão, inserção de conteúdos em vídeo ou áudio, blogs ou construção de uma rede articulada que pudesse unir diferentes instituições culturais na troca de informações, pesquisas e procedimentos que envolvem o campo da museologia e das Artes.

A fase inicial contou com o estudo dos sites de museus e centros culturais nacionais e internacionais, tais como: Centro Georges Pompidou, MAC USP, MAM SP, Instituto Itaú Cultural, MoMA, TATE, Museu Reina Sofia, Bienal SP, Bienal Mercosul, Documenta Kassel e Malba.

O que quase todos os sites tinham em comum era a disponibilização de um catálogo online de seu acervo, com a digitalização das obras e informações institucionais. Em alguns casos, tentava-se recriar no espaço virtual o ambiente físico do museu, com a visita virtual às galerias e salas em que a imagem das obras é apresentada em uma espécie de exposição virtual.

Com esse resultado, observou-se que a ocupação dos museus no campo virtual ocorria de diferentes formas e propósitos. A informação sobre Arte nem sempre aparecia como ponto de destaque no site. 
Optou-se, então, por identificar aquelas instituições que dispunham de publicações especializadas, voltadas para o universo das Artes Visuais e da Museologia, e que disponibilizavam esse conteúdo de forma integral em seu site.

Logo, percebeu-se que poucas eram as instituições que conseguiam organizar em um único espaço as informações sobre o discurso da crítica e da história arte, a informação institucional e sua orientação curatorial. Na maioria, essas informações aparecem diluídas dentro das diferentes seções e áreas do site, sem o compromisso de estarem reunidas dentro de uma seção publicada pela instituição e que garanta seu posicionamento político e institucional.

O que grande parte dos sites oferece é, na verdade, uma espécie de boletim informativo sobre as atividades do museu ou uma publicação didática direcionada ao público visitante, preparando-o para a experiência da visita à sede do museu.

Nesse momento, a única publicação encontrada que foi disponibilizada dentro de um site é a TATEETC. Trata-se de uma revista impressa publicada três vezes ao ano pela TATE e que tem seu conteúdo disponibilizado na rede. A revista explora o universo das Artes Visuais unindo arte contemporânea e história da arte, não se restringindo a comentar apenas o que acontece dentro dos limites da instituição.

A TATE é uma importante instituição cultural internacional. Fundada em 1897 por Henry Tate, em Londres, Inglaterra, ela conta hoje com quatro galerias que abrigam importantes coleções de arte britânica e internacional, do período de 1500 até os dias atuais. Atualmente, a TATE abriga em suas instalações cerca de 65 mil obras, divididas entre as quatro galerias: TATE Britain, Modern, St. Ives e Liverpool.

Entre 2009 e 2010, mais de sete milhões de visitantes passaram por uma das galerias TATE na Inglaterra e seu site, o portal TATE Online, teve cerca de 18,9 milhões de acessos no período. Isso faz da TATE uma importante fonte de pesquisa e, no que diz respeito às mudanças ocorridas no cenário das artes, no papel e na função da crítica, e nas transformações culturais e sociais que as inovações tecnológicas trouxeram à sociedade contemporânea.

A partir dessas questões, buscou-se encontrar, no cenário nacional, como as instituições museológicas estão tratando das questões relacionadas às novas tecnologias e do papel do museu enquanto agente formador e propositor de novas perspectivas para o universo das Artes frente essas modificações.

Encontramos no MAC USP um espaço aberto para esse debate. O Museu de Arte Contemporânea da Universidade de São Paulo, fundado em 1963 a partir da doação do acervo que constituía o antigo MAM SP e das coleções particulares dos Matarazzos ${ }^{5}$, foi um

\footnotetext{
${ }^{5}$ Francisco Matarazzo Sobrinho e sua esposa Yolanda Penteado.
} 
dos primeiros museus brasileiros a ter um endereço na Internet destinado a apresentar as questões relacionadas ao dia a dia do museu. Sua coleção reúne cerca de 10 mil obras, entre pinturas, desenhos, gravuras, fotografias, esculturas, objetos e obras de arte conceitual e de arte contemporânea, constituindo-o como um dos mais importantes museus de arte moderna e contemporânea da América Latina.

Além da importância relacionada ao lançamento do site, o MAC USP alimentava a ideia de criar uma publicação online especializada em Artes Visuais, que preencheria uma lacuna decorrida do enxugamento do espaço impresso e do discurso da crítica de arte, em consequência do surgimento da indústria cultural.

Dessa forma, decidiu-se estruturar o estudo a partir da análise dos endereços online dessas duas instituições, TATE e MAC USP, observando como se dá a comunicação virtual desses museus de arte e de que modo eles se utilizam do Ciberespaço como um novo campo para a comunicação do discurso sobre a Arte.

A pesquisa desenvolveu-se com o apoio de bibliografias sobre o tema e de estudo de fontes primárias, especialmente os dois sites da Internet, assim como as revistas que publicam. Foram desenvolvidas, ao longo do estudo, diversas questões e hipóteses para amparar a formulação de um processo metodológico de trabalho baseado no recurso dedutivo/indutivo e dialético. Foram também realizadas entrevistas.

A delimitação e investigação do objeto de estudo e a formulação de questões/problemas ajudou a estruturar e formatar o desenvolvimento do trabalho, a partir do levantamento de dados e hipóteses iniciais.

Ao longo do processo, o projeto precisou ser revisto, pois algumas das hipóteses levantadas não eram suficientes para responder a uma análise comparativa dos dois sites.

Considerando o caráter dinâmico e o potencial de transformação e atualização presentes no universo das inovações tecnológicas das quais a Internet faz parte, foi preciso repensar o objeto de estudo enquanto parte integrante desse mecanismo que também está em constante mudança.

Foram elaboradas tabelas de análise e comparação dos sites, e questões que serviriam de base para avaliar sua aproximação ou distanciamento em relação ao problema levantado.

Sendo assim, partiu-se da realização das seguintes questões:

o Como se dá a ocupação do Ciberespaço pela Arte e cultura;

o Que tipo de informação os sites de museus comunicam;

o Em que medida os sites são extensões dos museus;

o Que tipos de recursos os sites de museus oferecem enquanto soluções para minimizar as possíveis perdas estéticas decorrentes da migração para o campo virtual; 
o Qual o discurso sobre arte veiculado;

- As revistas online são um novo campo para se projetar uma reflexão sobre arte ou um suporte para divulgar a própria instituição;

Posto isso, no primeiro capítulo desta dissertação será apresentado um panorama do surgimento da Internet e a emergência do Ciberespaço e sua implicação nas formas de ser, conhecer e se comunicar. Será também apresentado o modo como o espaço virtual passou a ser ocupado pelas instituições culturais e quais os tipos de sites de museus encontrados hoje na rede.

No segundo capítulo será desenvolvida a análise dos sites da TATE e do MAC USP observando seus históricos, quando surgiram, que tipo de informação trazem, como estão organizados e estruturados, como são produzidos, quais os diferenciais e em que medida podem ser pensados enquanto plataforma de atuação dos museus para além de suas instalações físicas.

No terceiro capítulo serão tratadas diretamente as questões relacionadas às publicações realizadas pelas duas instituições como espaço para a veiculação de conteúdos críticos sobre o debate atual no universo das Artes, e como essas publicações podem ocupar o espaço virtual e se aproximar do público a partir dos recursos tecnológicos que a Internet oferece.

Sendo assim, o presente trabalho não tem a pretensão de esgotar o tema e sim; de traçar um panorama de como os sites estudados passaram a habitar o Ciberespaço e quais as transformações que esse tipo de comunicação pode trazer na forma do visitante/internauta aproximar do universo das Artes, tendo como ponto de entrada os sites de museus e a mediação promovida pela tela do computador e pelos recursos tecnológicos disponíveis de rede mundial de computadores. 


\section{CAPÍTULO 1 \\ O MUSEU DE ARTE E O CIBERESPAÇO}




\subsection{O surgimento da Internet: A Arte e o Espaço Virtual}

O aparecimento da Internet, nome utilizado para se referir hoje à rede mundial de computadores, deu-se nos EUA por volta dos anos 1960 e está inicialmente ligado às pesquisas militares que se desenvolveram durante o período da Guerra Fria. Até os dias atuais, muitas foram as mudanças e vários setores apropriaram-se desse novo meio de comunicação.

Idealizada para servir como um modelo de troca e compartilhamento de informações que permitisse sua descentralização, visando assim diminuir os riscos iminentes do pósGuerra como perda e roubo de dados, bombardeios, etc., foi criada a ARPANET, que funcionava por meio de um sistema de transmissão de dados em rede de computadores no qual as informações eram divididas, permitindo a remontagem da mensagem original por um outro computador.

Na década de 1970, o governo dos EUA permitiu que pesquisadores universitários tivessem acesso a ela, e o desenvolvimento da rede pôde acontecer de forma livre e acelerada. Nesse período, surgiu também o que seria uma das principais aplicações da Internet, o correio eletrônico; e o movimento social da Contracultura, nascido na Califórnia, ajudou nas inovações técnicas que iriam culminar na invenção e comercialização do computador pessoal, agregando às funções já conhecidas de processamento e cálculo de informações a criação de textos, imagens, jogos e músicas.

A partir dos anos 1980, a informática passou a aproximar-se cada vez mais do setor de telecomunicações, o que levaria à formação de um espaço de acesso à informação e ao conhecimento, um lugar para a troca de ideias, de socialização e formação: o Ciberespaço.

Desde o princípio, a Internet surge a partir da cooperação e compartilhamento de dados. Seus usuários relacionam-se, criam, circulam, compartilham e gerenciam as informações na rede, independente de um órgão ou organismo centralizado. Esse é o espírito da Internet que vai aflorar e ampliar no Ciberespaço: a independência, a autonomia e a valorização do outro, visando um processo de construção coletiva.

Os usuários, ou seja, as pessoas que navegam na Internet, são responsáveis por definirem para onde elas irão, isto é, o tipo de aplicação, a velocidade e o desenvolvimento das tecnologias em rede, acesso, qualidade e quantidade de informações. Dessa forma, poder-se-ia pensar que apenas quem detém a informação ou, pelo menos, quem consegue acessá-la - países do hemisfério Norte, cidadãos dos grandes centros urbanos, determinadas maiorias que falam certo idioma - são capazes de produzir conteúdos na rede e de torná-los acessíveis. Na verdade, a grande inovação desse tipo de estrutura, que é também o que não a deixa se tornar obsoleta, é sua capacidade de suspensão do tempo e 
do lugar, sua habilidade em produzir e reproduzir realidades globais a partir de experiências locais.

Por intermédio de comunidades virtuais, grupos de pessoas organizados em torno de interesses e temas comuns, pode-se estabelecer relações de sociabilização, de troca, experiências e relações humanas. Pela primeira vez a comunicação dá-se de maneira direta, não midiatizada e não censurada: qualquer um pode escrever o que quiser, sobre o que quiser.

E é justamente nisso que se encontra um dos principais problemas da Internet: a credibilidade. Se o espaço virtual aceita todo tipo de publicação, como garantir a veracidade da informação, sua autoria, referências, dados, etc.?

Nesse sentido, a Internet aproxima-se do mundo real. Sem a validação e a constatação dada por um veículo de informação impresso, uma rede de notícias, um organismo ou empresa de reconhecimento nos meios de comunicação, o espaço virtual torna-se um grande emaranhado de notícias, uma espécie de diário virtual em que qualquer um pode escrever o que lhe convier sem a preocupação com a veracidade da informação.

Torna-se imprescindível o reconhecimento do mundo real. É necessário encontrar nele referências, garantias, marcas, pessoas de credibilidade que atestem e garantam que sua atuação no mundo virtual é tão verdadeira quanto no real.

Para Castells ${ }^{6}$, "a Internet é o coração de um novo paradigma sociotécnico, que constitui na realidade a base material de nossas vidas e de nossas formas de relação, de trabalho e de comunicação. O que a Internet faz é processar a virtualidade e transformá-la em nossa realidade, constituindo a sociedade em rede, que é a sociedade em que vivemos".

Vive-se, então, a era da Cibercultura, ou, em outras palavras, a cultura do Ciberespaço. Uma época mediada pela presença simultânea do aqui e agora, pela virtualização do meio e da mensagem e pela modificação das práticas, atitudes, pensamentos e valores. O acesso relativamente fácil e rápido à rede mundial de computadores, a Internet, não somente alterou o modo como as pessoas relacionam-se com o mundo a sua volta, mas também redesenhou as fronteiras entre o real e o virtual. Relativizando as experiências e globalizando as realidades, cada um pode se reconhecer e se transformar de acordo com o cotidiano e a realidade do outro. Por mais local que se julgue ser uma determinada realidade, ela, eventualmente, encontra reverberações e desdobramentos em locais aparentemente diversos.

6 CASTELLS, Manuel. Internet e sociedade em rede. In: Por uma outra comunicação: mídia, mundialização, cultura e poder. Dênis de Moraes (org.). Rio de Janeiro: Record, 2003, p. 287. 
Pierre Lévy ${ }^{7}$ compara a reorganização das realidades, proclamada pela Cibercultura, com o que ocorrera com as sociedades orais:

\begin{abstract}
A cibercultura leva à co-presença das mensagens de volta a seu contexto como ocorria nas sociedades orais, mas em outra escala, em uma órbita completamente diferente. A nova universalidade se constrói e se estende por meio da interconexão das mensagens entre si, por meio de sua vinculação permanente com as comunidades virtuais em criação, que the dão sentidos variados em uma renovação permanente.
\end{abstract}

Nessa nova organização do tempo e do espaço, o Ciberespaço é o lugar que surge da conexão mundial dos computadores. O termo especifica não apenas a infraestrutura material da comunicação digital, mas também o meio de se comunicar, agir, pensar e de se relacionar com ele.

O espaço virtual aparece como suporte da inteligência coletiva, ou seja, sua estrutura colaborativa, de auto-gestão e a possibilidade de integração entre os usuários estimulam a criação e o aprimoramento do próprio espaço, e esta é umas das principais condições de seu próprio desenvolvimento.

É importante dizer que o espaço virtual não pretende, ou não deveria, substituir o espaço real, físico, o espaço tradicional e estabelecido em que as relações e interações humanas desenvolvem-se.

Há, atualmente, duas possibilidades de entradas no Ciberespaço: a Realidade Virtual, que simula uma imersão por meio dos cinco sentidos, onde o usuário é convidado a interagir de modo sensório-motor com o mundo digital - através da criação de diversas interfaces: telas, teclados, óculos, mouse, etc. A outra entrada, a Realidade Ampliada, potencializa as condições e características do ambiente físico em que se encontra o usuário por intermédio do uso de sensores, câmeras e projetores interconectados.

Vale dizer que nenhuma delas substitui a experiência presencial, pelo contrário, elas são constantemente atualizadas, reinventadas e modificadas. A experiência virtual simula a realidade a nossa volta, e também modifica nossa percepção; dessa forma, ela se comunica de maneira mais eficaz e extrapola o aqui e agora, condição necessária anteriormente para que se estabelecesse, de forma efetiva, a comunicação.

Uma das funções do Ciberespaço é o acesso aos diversos recursos de um computador, permitindo a interação entre eles. Para Lévy, três princípios norteiam o crescimento do Ciberespaço: a interconexão, a criação de comunidades virtuais e a inteligência coletiva.

A interconexão, isto é, a conexão simultânea de vários computadores ao redor do mundo, permite a interação entre vários meios de comunicação, compartilhamento de

\footnotetext{
${ }^{7}$ LÉVY, Pierre. Cibercultura. São Paulo: Editora 34, 1999, p. 15.
} 
arquivos e informações, utilização de correio eletrônico (e-mail), e outros recursos que formam a grande rede de conexões que é a Internet.

As comunidades virtuais criaram novas formas de encontro e manifestações de opiniões dos usuários. Elas aproximam grupos que tem interesses, gostos e discussões em comum, e que antes eram apenas pequenas minorias sem grande ou nenhuma representatividade. É o que Lévy ${ }^{8}$ chama de "ideal de relação humana desterritorializado", ao aproximar diferentes contextos em torno de um fim maior.

Já os processos de criação e colaboração coletivas, que fazem uso de sistemas de interconexão e de pesquisa, como a World Wide Web ( w.w.w.), são os responsáveis pelas constantes modificações e atualizações da rede mundial de computadores. É a demanda dos próprios usuários que favorece seu desenvolvimento.

Essa nova realidade que o Ciberespaço impõe ao cidadão atual transforma também sua relação e seu modo de perceber a realidade. A forma de se comunicar, de se relacionar, ler, raciocinar e escrever é agora mediada pelo Ciberespaço e compartilhada por milhões de outros usuários da Internet. Na esfera cultural, essas transformações afetam também a maneira como as Artes e os Museus, até então únicos legitimadores e reconhecedores do potencial artístico de determinada obra, vão se relacionar com seus visitantes, sejam eles no mundo virtual ou presencial.

\subsection{O Ciberespaço como um novo lugar da Arte}

Desde sua criação, os Museus formulam seu discurso e constroem seu conhecimento baseados em imagens ou nos objetos por ele abrigados. Mesmo o que ocorrera no século XIX, com a invenção da fotografia e a reprodução rápida e sistematizada das obras de arte, não afastou o visitante do Museu, ao contrário, a sensação que ele experimentava ao ver a obra original, depois de ter acessado, das mais diversas formas, sua reprodução, contribuía para atualizar e formar o ideal de imagem por ele construído. A obra era assim, constantemente reatualizada, posta em circulação, consumida e experimentada pelo público. O ideal de criação, aquele momento em que o artista é agraciado com o dom e inspiração que o fazem transpor os limites do humano e ganhar status de divino também era há bem pouco tempo; cultuado.

Com a expansão e o crescimento da Internet, diferentes formas de atuação e utilização dos recursos disponíveis na rede foram experimentadas pelos artistas. Desenvolveram-se novas formas de fazer e perceber a arte. A Ciberarte, como ficaram

\footnotetext{
${ }^{8}$ Ibidem, p. 130.
} 
conhecidos os trabalhos pensados para o mundo virtual, acontece no espaço de ação e criação da Internet, e utiliza de suas ferramentas, tais como: som, vídeo, projeção, imagem, texto, tudo conectado. Cria-se, assim, novas interfaces e maneiras de apreciar a obra. Uma nova estética precisa ser descoberta e um novo discurso sobre arte emerge nesse campo: a construção do objeto de arte, nesse meio, faz-se de forma coletiva e colaborativa. Interessa mais, ao artista da Cibercultura, as possibilidades de entradas, discursos, discussões e desdobramentos que a obra vai gerar, do que o próprio objeto acabado, ainda que virtual.

Essa nova forma de arte, na qual não se conhece os limites para a conservação, exibição, classificação e documentação, requer um outro entendimento por parte dos críticos, curadores e das próprias instituições museológicas de como conhecer e intervir nos processos que circundam a obra.

Se até então a obra a ser conservada em um museu era a peça acabada, finalizada, que era em si o meio e a mensagem do artista, com a Ciberarte, a obra esta constantemente em construção, ela não pode ser finalizada porque é resultado de um processo contínuo de construção coletiva; sua documentação, registro e data de criação, não podem ser medidos por que ela está sempre se modificando em uma velocidade mais ou menos intensa, de acordo com o número de entradas e a interação de seus usuários na rede.

Diante disso, a primeira ação por parte dos Museus, no sentido de tentar entender e apreender todo o potencial disponível no Ciberespaço foi virtualizar seu acervo e torná-lo disponível, por meio de um endereço eletrônico, na Internet.

Nesse caso, a representação é substituída pela virtualização, muitas vezes interativa, da obra.

Para Levy ${ }^{9}$

Quanto mais difundidos os elementos recombináveis do museu imaginário, mais foram fundados prédios abertos ao público cuja função era abrigar e expor a presença física das obras. Ainda assim, se estudássemos o destino de determinado quadro célebre, descobriríamos que foi apreciado mais frequentemente como reprodução do que como original. Da mesma forma, os museus virtuais provavelmente nunca farão concorrência aos museus reais, sendo antes suas extensões publicitárias. Representarão, contudo, a principal interface do público com a obra.

Há uma valorização das cópias e reproduções das obras. Os museus, que até então eram os depositários de determinado original, agora as reproduzem, fazem circular na rede e chegar a um número cada vez maior de pessoas, ao mesmo tempo em que se distanciam do potencial colaborativo do Ciberespaço. Cria-se um grande cardápio virtual de obras que em nada se aproximam ou o aproximam da instituição como muito se pensou.

\footnotetext{
9 Ibidem, p.154.
} 
O Ciberespaço abriga uma série de tecnologias que aumentam, modificam e exteriorizam as funções cognitivas e o potencial humano. Os usuários que navegam pela rede não mais adotam a postura passiva que se verificava nos processos de comunicação anteriores. Ele quer se comunicar, manifestar sua opinião, conhecer, pesquisar, compartilhar e construir um discurso.

Ao entrar no site, no endereço virtual do museu, ele espera encontrar informação sobre sua coleção, acervo, visitação, textos, etc. Mais do que isso, espera que esse lugar seja como o restante do espaço virtual que ele conhece: lugar em que busca e cria suas referências, interage com diversas mídias, cria novas formas de escrever, ler, ouvir e pensar, é estimulado a raciocinar segundo seus próprios critérios e, pode tirar suas conclusões sobre determinada exposição, artista ou obra, compartilhando com os outros visitantes essas impressões. Essa é uma maneira de explorar e utilizar a principal ferramenta que o Ciberespaço oferece: a construção do conhecimento e a transmissão dos saberes nas comunidades virtuais, grupos de pessoas que se organizam virtualmente em torno de um interesse comum.

Dessa maneira, consegue-se alcançar o potencial que a Cibercultura oferece, que é sua principal vantagem: a transmissão dos saberes passa a ser feita pelos grupos e comunidades humanas, onde as comunidades virtuais atuariam de forma a preservar, divulgar e elaborar o conhecimento sobre determinado assunto, autogerenciando sua produção e colaborando com a criação de novas ideias e conceitos sobre determinados assuntos.

Na prática, Lévy ${ }^{10}$ observa que não foi bem isso que aconteceu:

(...) os museus virtuais muitas vezes nada mais são do que catálogos ruins na
Internet, enquanto é a própria noção de museu como fundo a ser conservado que é
colocada em questão pelo desenvolvimento de um ciberespaço onde tudo circula com
uma fluidez crescente e onde as distinções entre original e cópia evidentemente não
tem mais valor. Em vez da reprodução das exposições clássicas em sites ou displays
interativos, seria possível conceber percursos personalizados ou então
constantemente reelaborados pelas navegaçães coletivas em espaços totalmente
desvinculados de qualquer coleção material. Mais pertinente ainda seria o
encorajamento a novos tipos de obras: espaços virtuais a serem investidos e
atualizados por seus exploradores.

O que acontece com a maioria dos sites de museus é uma tentativa de simular e transpor sua realidade física para o espaço virtual. O site é pensado como um veículo de informação e não como mais uma plataforma de atuação e formação de público em si, como são as exposições, cursos, palestras, serviços educativos e outras atividades realizadas pelas instituições museológicas.

\footnotetext{
${ }^{10}$ Ibidem, p. 188.
} 
No entanto, é preciso repensar a própria estrutura de comunicação a que esse visitante está sujeito. A maioria dos usuários da rede são pessoas jovens, estudantes, professores, pesquisadores, para quem essa estrutura de comunicação passiva, do tipo boletim eletrônico, não é interessante. O visitante logo se desinteressa se não consegue achar, rapidamente, as informações que ele deseja. A criação de hipertextos, as combinações multimidiáticas que misturam arquivos de som, imagem, texto e vídeo são cada vez mais procuradas pelos usuários que, no caso do Brasil, costumam passar cerca de 25,8 horas na Internet por mês, 8 horas assistindo a vídeos online ${ }^{11}$. Esse tempo é gasto com todo tipo de atividades: compras, visita a sites de relacionamentos, pesquisas, cursos, bate-papo, informações, atualizações, jogos, entretenimento, etc.

No caso dos museus, desde o início houve a preocupação com a substituição da visita física, presencial, pela visita virtual, aquela a que o visitante tem acesso ao entrar no site da instituição. Tem-se uma grande preocupação em que o conhecimento sobre arte seja feito apenas pelo reconhecimento de reproduções de imagens de grandes obras presentes nas mais diversas instituições. Essa preocupação sempre existiu, mas mesmo com a multiplicação de imagens, camisetas estampadas, pôsteres, canecas, calendários e todo tipo de objeto, nada disso impediu sua visitação, pelo contrário, em muitos casos, estimulou.

O visitante virtual sabe que nenhuma obra, por maior que seja a riqueza de detalhes com que ela tenha sido digitalizada, substitui a experiência física da visita ao espaço do museu e aproximação com a Arte. Na verdade, os museus online e seus grandes catálogos virtuais disponíveis na rede tendem a aumentar o interesse e o contato com essa informação, estimulando a participação e a curiosidade pela materialidade das obras em seu acervo. Não é, definitivamente, essa a questão a ser discutida. Não se trata de substituição, mas de abertura e criação de novos padrões estéticos e culturais iniciados com o Ciberespaço, e que dizem respeito a como vamos interagir, reagir e receber as novas manifestações e formas de exibir arte que levam em conta as possibilidade e ferramentas do mundo virtual.

Mas se, como já se observou, o Ciberespaço é produto daquilo que as pessoas armazenam nele, como confiar que determinada informação sobre arte é realmente verdadeira? A questão da autoria na Internet ainda é muito discutida. Os sites são produzidos e mantidos por instituições e pessoas que assinam e atestam sua veracidade junto às comunidades virtuais. E alguns deles são avaliados como "confiáveis" ou "não confiáveis" pelos internautas, assim como a qualidade de seus serviços, incluindo a informação por eles veiculada. Dessa forma, os próprios internautas fiscalizam a informação disponível no Ciberespaço.

${ }^{11}$ Pesquisa disponível em http://tecnologia.uol.com.br/ultimas-noticias/redacao/2011/05/03/brasileiro-gasta-emmedia-8-horas-por-mes-assistindo-a-videos-online-indica-pesquisa.jhtm, acesso em maio de 2011. 
Quando uma informação virtualiza-se, quando entra na rede, ela automaticamente desterritorializa-se. Ao assumir o espaço virtual, sua presença é relativizada, podendo assumir diferentes contextos, interesses, temas, gostos; enfim, pertencer a diversos grupos sem necessariamente estar ligado a nenhum.

Nesse sentido, os sites de museus, que começam a ganhar força especialmente a partir da década de 1990, assumem o papel de ocupar a rede e informar, também para o público virtual, que tipo de informação sobre Arte é aceita no momento, quais são as influências, tendências, artistas e obras que estão em discussão.

Nesse cenário, os museus de arte contemporânea são os que parecem mais propensos a ingressar nesse novo espaço pela própria natureza de suas coleções. Se a arte contemporânea desafiou os métodos até então tradicionais de classificação, restauração, guarda e criação de suas obras, os museus de arte contemporânea, ao entrarem no Ciberespaço, potencializam e criam novas discussões em torno das estéticas tradicionais e meios de aproximação com o público.

Nos sites, as obras, assim como o próprio museu, não ganham apenas maior visibilidade, mas têm seu potencial de atualização multiplicado. Um museu, ou a imagem que o museu projeta na Internet por meio de seu site, será mais reconhecida à medida que forem maiores as entradas e o número de acessos ao site, ou seja, a capacidade de reproduzir em si mesmo a imagem virtual e potencializada das obras de seu acervo.

Muitos museus percebem que mais do que um simples catálogo virtual e espaço de divulgação de atividades e serviços, o Ciberespaço pode se constituir como uma valiosa ferramenta de alcance, formação e interação com o usuário, que muitas vezes nunca foi à sua sede. Essa é a uma das conclusões que esta pesquisa pretende chegar, que tipo de conteúdo sobre arte e formação de público os sites de museus podem gerar na era da informação?

Que tipo de atrativos e de vantagens pode ter um site de museu que substitua a presença física do visitante e o contato direto com a obra?

O Ciberespaço atrai um novo tipo de visitante ao museu: aquele que provavelmente nunca conhecerá sua sede física e não terá acesso às obras em sua coleção e ao discurso criado em determinada exposição; contudo trará como referência o endereço virtual que ele encontra na Internet e a ideia de museu e arte que está disponível no mundo virtual. São esses elementos com os quais ele construirá sua informação e o discurso sobre Arte.

Nenhum site pode ter a pretensão de substituir ou recriar a experiência vivenciada pelo visitante ao ter contato direto com a obra. Ao contrário, na Internet, os museus lidam com outro tipo de público que não é mais o espectador, mas sim o internauta, o que realiza diversas e simultâneas ações; lê, ouve, assiste a vídeos e imagens e tem a capacidade de interagir e procurar informações na rede. 
Suas habilidades integram a velocidade da comunicação oral ao trabalho mais intelectual exercido na leitura, tudo permeado no Ciberespaço pela interconexão e interação entre os usuários.

Ao falar de museus na Internet, deparamos com diversos nomes: Cibermuseu, Museu Virtual, Museu Online, Webmuseu. Mais adiante serão detalhados alguns deles que foram considerados pertinentes à compreensão desta pesquisa, todavia, o fato é que a própria terminologia usada para classificá-los visa aproximar, ao máximo, da ideia de museu enquanto instituição física, que busca na credibilidade e no reconhecimento de sua trajetória no espaço real sua equivalência no Ciberespaço.

Muitas vezes a própria arquitetura do museu é replicada e simulada no meio virtual. São construídas paredes e salas com exposições virtuais e imagens das obras digitalizadas, replicadas nas paredes. Às vezes, a própria exposição em cartaz no museu tem sua versão virtual disponibilizada no site.

Em uma breve análise dos sites de museus e instituições culturais existentes no Brasil e em alguns países como Estados Unidos, França, Espanha e Inglaterra notou-se que pouco se entende sobre o que é o Ciberespaço e seu potencial de formação e transformação. A maioria dos sites é, na verdade, catálogos virtuais que tem suas obras em acervo digitalizadas, com informações sobre o autor, técnica, período, corrente artística, e o serviço do próprio museu: endereço, horário de funcionamento, biblioteca, cursos e demais atividades realizadas em sua sede.

As atividades na Internet aparecem, normalmente, ligadas às realizadas pelos museus em seus espaços físicos. Não há uma apropriação dos recursos virtuais. Os sites de museus precisam estar vinculados à marca e ao prestígio da instituição; isso lhes garante o reconhecimento e a confiança, por parte dos usuários, de que aquela informação disponibilizada online é realmente confiável. Mas não precisam, necessariamente, ser uma cópia do que se encontra disponível para visitação.

Com isso, optou-se por analisar comparativamente dois sites de museus, do MACUSP e da TATE, que acreditamos ter, cada um da sua forma, algumas das características essenciais a um bom site de museu. A escolha, obviamente, passa também pela credibilidade de sua imagem, pela importância e relevância de suas coleções, de suas pesquisas desenvolvidas junto à comunidade acadêmica e por seu pioneirismo; ambos foram um dos primeiros representantes de seus países a disponibilizarem um site na Internet, no Brasil e na Inglaterra, respectivamente.

Uma análise comparativa de ambos não visa apresentar qual o melhor ou pior, mas perceber a quais soluções e entendimentos chegaram-se, em contextos diferentes, e que são necessários para se construir um espaço de aprendizagem, colaborativo e interativo, na Internet. Na verdade, esse é o grande desafio ao se lançar um site na rede; como ele pode 
agir de forma a garantir a manutenção do projeto político da instituição e estimular seu crescimento lidando com diferentes públicos ao redor do mundo que não necessariamente terão acesso ao espaço físico do museu, mas ainda sim querem ampliar seu conhecimento e entendimento sobre Arte.

O projeto dos museus já não é mais centrado na gestão de suas coleções com a função de internacionalizar e globalizar as reflexões locais, ligadas a determinado contexto ou época, com seus sites há a ressignificação da reprodução desterritorializada de seu patrimônio que circula na rede, da construção coletiva do discurso e informação sobre Arte que habita a Internet.

Se um dos principais efeitos da transformação nos meios de comunicação experimentados com a Internet foi a possibilidade de construção de coletivos inteligentes e de uma forma de comunicação não midiática, em que o foco da informação é centrado no interesse do emissor-receptor, ou seja, o internauta, esse efeito ainda não pôde ser sentido de forma eficiente nos sites de museus.

No levantamento preliminar realizado no início desta pesquisa, verificou-se que os museus ocuparam a rede da Internet apenas por identificar nela sua eficiência de alcance e comunicação com os usuários, como um meio eficiente de divulgação de suas atividades, e não pelo potencial de colaboração do Ciberespaço.

É verdade que as tecnologias informacionais ligadas à criação e evolução dos serviços e recursos da Internet são relativamente novas e estão em constante mudança e atualização. Essa é uma característica necessária a seu funcionamento. É verdade também que o número de usuários da rede vem crescendo e, de certa forma, aumentando seu potencial de interação e circulação de mensagens. Porém, as ações em torno da criação de novos projetos educativos e museográficos para o uso e aplicação das novas tecnologias da informação, a fim de revitalizar a imagem dos museus e torná-los mais acessíveis e interativos aos visitantes, ainda são escassas.

Muitas ações ainda esbarram na necessidade de replicar o modelo já conhecido de virtualização do real. Outro fenômeno a ser observado é a existência de lojas online dentro desses sites que multiplicam a reprodução do acervo em camisetas, pôsteres, quadros e todo tipo de souvenir que remete à lembrança da visita ao museu, agora não mais ao seu edifício, mas ao site e à loja virtual, ou seja, o visitante pode ver a exposição e comprar sua lembrança sem nunca ter saído de casa.

\subsection{Um Novo Museu para o Ciberespaço}

O campo das Artes, assim como outras áreas do conhecimento, apropriou-se rapidamente das novas tecnologias digitais, influenciado principalmente pela velocidade nos 
meios de informação e comunicação, dando início aos processos de virtualização e relativização das estéticas e percepções, e ampliando seu acesso e relacionamento com o público. Foi assim com a fotografia, o vídeo, e mais recentemente, com a Internet.

Nesse momento, faz-se necessário estabelecer uma distinção entre a virtualização dos meios e dos processos, etapa na qual se incluem também os sites de museus, e as chamadas Artes Digitais, construídas no Ciberespaço, e que utilizam de seus recursos tecnológicos e suas ferramentas para a criação da obra em si. Se a Arte, e de certa forma seus agentes intermediários: museus, galerias, críticos, curadores, marchands, de alguma forma sempre se apoderaram, ao longo da História, das inovações tecnológicas para construir seu discurso, sua entrada na Internet, sua constituição enquanto rede sistematizada de informação, resignificou e questionou sua própria atuação. Hoje, pensa-se: Qual é, realmente, o papel dos museus e instituições culturais na legitimação dos processos de produção, circulação e difusão das obras no Ciberespaço? E, além dos espaços museológicos já consagrados, quais os novos espaços digitais da arte contemporânea?

Nesse sentido, Cauquelin ${ }^{12}$ destaca a importância do sistema em rede para a arte contemporânea:

\begin{abstract}
Uma das características do poder da rede é o fato de ela deslocar o poder de decisão: ele não é mais central, não tem mais local próprio, não parte de um sujeito ou de um grupo de sujeitos para se transmitir às periferias; mesmo uma instituição localizada e centralizada só tem poder na medida em que é capaz de estar presente dentro de toda a rede ao mesmo tempo. Não será verdadeiramente ativa a não ser pelo número e pela diversidade de suas conexões.
\end{abstract}

É nesse contexto que os sites de museu vão atuar, seu desafio é, enquanto espaços de legitimação da Arte já consagrados, manter-se ativo e influentes também na Internet, além de se comunicar com diferentes pessoas conectadas que, não importa onde estejam, terão acesso aos seus conteúdos e serão capazes de opinar, construir e reconstruir um conhecimento coletivo sobre Arte.

Reconhecer e estabelecer, no Ciberespaço, a constituição de um lugar para a atividade crítica e a informação sobre Arte requer o desenvolvimento de uma terminologia própria, o estabelecimento de uma nova estética com padrões que extrapolem a leitura da obra ou, nesse caso, da imagem da obra, mas que levem em conta novas metodologias de criação e circulação da Arte.

Antes de iniciarmos a análise dos sites de museus que é o objetivo desta pesquisa, precisamos compreender uma questão que se faz emergente: Como diferenciar e reconhecer os espaços virtuais ocupados pelas Artes e suas variações no que diz respeito à nomenclatura e atuação enquanto difusor de conceitos e informações?

\footnotetext{
${ }^{12}$ CAUQUELIN, Anne. Arte Contemporânea: uma introdução. São Paulo: Martins, 2005, p. 69.
} 
De modo geral, os espaços ocupados pelos museus na Internet, sob o nome de Museu Online, Museu Virtual, Cibermuseu ou Webmuseu, apresentam algumas características em comum:

- Ampliam o acesso à imagem digitalizada da obra, presente ou não em seu acervo;

- Apresentam exposições virtuais que passaram ou não pelo aval de um curador (há muitos sites que permitem aos usuários a criação de sua própria exposição virtual que pode ser publicada na rede e torna-se disponível na rede);

- Criação de uma rede de sites que ampliam a identificação da produção artística e o relacionamento entre as instituições.

O propósito não é criar uma classificação dos tipos de museus que habitam a Internet, mas reconhecer que sua descrição encontra-se ainda ligada ao conceito e definição de Museu desde suas origens.

De acordo com o $\mathrm{ICOM}^{13}$, Conselho Internacional de Museus, Museu "é uma instituição permanente, sem fins lucrativos, a serviço da sociedade e de seu desenvolvimento, aberta ao público, que adquire, conserva, pesquisa, comunica e exibe, para fins de estudo, educação e lazer, evidência material das pessoas e de seu meio ambiente".

A ideia moderna de Museu está fortemente centrada em seu espaço físico, no lugar onde são expostos ao público suas obras e objetos musealizados, e onde é construído seu discurso.

Em 2001, durante a 20 Assembleia Geral do $\mathrm{ICOM}^{14}$, foram aprovadas novas emendas que admitiam centros culturais e outras entidades voltadas à preservação, manutenção e gestão de bens patrimoniais tangíveis e intangíveis como membros da categoria Museu.

Pode-se pensar que, assim como algumas instituições culturais não dispõem de um acervo permanente, mas ainda assim promovem exposições e exibem obras dentro de um discurso curatorial determinado, da mesma forma os Webmuseus, aqueles construídos e mantidos exclusivamente no Ciberespaço, podem então ser enquadrados dentro dessa categoria.

O ponto de partida dessa nova categoria de Museu não é mais a obra, ou o objeto em si, nem o espaço ou sua arquitetura, mas a informação que ele comunica e faz circular dentro da Web. Seu potencial enquanto produtor de informação multiplica-se à medida que se desvincula da noção de tempo e espaço.

\footnotetext{
${ }^{13}$ Disponível em http://icom.museum/who-we-are/the-vision/code-of-ethics.html, acesso em setembro de 2010.

${ }^{14}$ LOUREIRO, Maria Lucia de Niemeyer Matheus. Webmuseus de arte: aparatos informacionais no ciberespaço. Disponível em http://www.scielo.br/pdf/ci/v33n2/a10v33n2.pdf, acesso em março de 2010.
} 
Se para Kimmelman ${ }^{15}$ os Museus já foram considerados como "as novas catedrais do nosso tempo", hoje, a posse de uma coleção e até mesmo de um espaço físico em que o visitante reconheça a instituição não são mais os únicos parâmetros para classificá-lo e justificar sua existência.

Um bom exemplo de Webmuseus é o MUVA ${ }^{16}$, Museu Virtual de Artes El País, no Uruguai, que funciona exclusivamente na Internet. O MUVA reproduz no ambiente virtual exatamente aquilo que se espera encontrar ao visitar o edifício de Museu: entrada, recepção, elevador, corredores que dão acesso às salas de exposição, exposições temáticas, textos, além de imagens de seu projeto arquitetônico, planta baixa dos andares, imagem de satélite de sua localização; toda essa visita pode ser acompanhada, se assim o visitante desejar, de uma trilha sonora de fundo.

Essa ideia assemelha-se ao conceito de Museu Imaginário, de André Malraux ${ }^{17}$, ou seja, a criação de um lugar que abrigaria uma coleção com reprodução de todas as obras de arte do mundo, em que cada pessoa poderia ter seu próprio museu e coleção a partir de suas escolhas e propostas de curadoria.

É importante notar que, em ambos os casos, prioriza-se o uso da imagem como referência patrimonial. As características próprias da Internet lhe conferem configuração hipertextual, ampliando e potencializando as possibilidades de interação com a obra, além de transpor as limitações de tempo e espaço. Por não se ligarem a nenhuma instituição que garanta seu funcionamento, manutenção e recursos, podem assumir, eventualmente, um caráter provisório e de experimentação. Por outro lado, sua missão de compartilhar com a sociedade o acesso às imagens, coleções e informações aproxima-o dos Museus de arte construídos no espaço físico.

Outra distinção que se faz necessária é o que se convencionou chamar de Museu Virtual. Vamos utilizar, para esta pesquisa, a designação de Museu Virtual como aquele que se caracteriza a partir de uma virtualização do museu físico, ou seja, que está ligado a uma instituição estabelecida e regulamentada como Museu, e que dispõe, no Ciberespaço, de uma parte de seus conteúdos como forma de facilitar o acesso e estimular os processos de construção de conhecimento e informação experimentados pelo internauta ao navegar por suas páginas. Nesse caso, ambos os sites estudados, o MAC Virtual ${ }^{18}$, site do MAC USP, e o TATE Online ${ }^{19}$, site da TATE, constituem-se como museus virtuais, pois apresentam um projeto de usabilidade e interação com o usuário. Não tratam apenas de mostrar seu conteúdo digitalizado ou de explorar o espaço como ferramenta de marketing, mas

\footnotetext{
15 LOUREURO apud KIMMELMAN, Michael. O futuro dos museus no século XXI. Jornal do Brasil, Rio de Janeiro, 11 de setembro de 2001, p.8.

${ }^{16}$ Disponível em http://muva.elpais.com.uy/ , acesso em maio de 2011.

17 MALRAUX, André. O Museu Imaginário. Lisboa: Edições 70, 2000.

${ }_{18}^{18}$ Disponível em http://www.mac.usp.br/mac/, acesso em maio de 2011.

19 Disponível em http://www.tate.org.uk/, acesso em maio de 2011.
} 
constituem-se como um espaço de mediação e de construção permanente de conhecimento.

Nos próximos capítulos, serão estudados de que maneira esses dois sites estabelecem ligações com os usuários, quando surgiram, de quais recursos e ferramentas utilizam-se para se aproximar e se comunicar com o público e que tipo de informação sobre Arte podemos encontrar em suas páginas. 


\section{CAPÍTULO 2 OS SITES DE MUSEU E A FORMAÇÃO DO PÚBLICO - APRECIAÇÃO SOBRE A TATE E O MAC - USP}




\subsection{Tipos de sites de Museus}

Nesse momento, é necessário citar outra tipologia de sites de museus criada por Márcia Piacente ${ }^{20}$, diretora da revista italiana Pedagogika.it ${ }^{21}$, em 1996. Essas classificações buscam avaliar o grau de interação do museu com o usuário e o nível de entendimento acerca do potencial do Ciberespaço e sua aplicação pela instituição.

Para Piacente, pode-se dividir os sites de museus em três grupos:

- Folheto eletrônico: aqueles sites cujo objetivo é a apresentação do museu físico, usando a Internet como ferramenta de comunicação e marketing a fim de projetar e potencializar na rede a imagem da instituição, de forma a garantir uma repercussão maior, o que se reverteria em um maior número de visitantes. Normalmente, esse tipo de site usa recursos de interface muito simples, o usuário encontra poucas ferramentas de interação e sua navegação nesse tipo de ambiente não costuma durar muito;

- Museu no Mundo Virtual: esse tipo de site apresenta informações mais detalhadas da instituição. O site, muitas vezes, acaba projetando o próprio museu no espaço físico, por meio de recursos como visita virtual, acervo online, exposições virtuais, etc. Apesar de prever uma maior interação do usuário e utilização dos próprios recursos de que a Internet dispõe para o estabelecimento de uma mediação que supõe a participação do internauta e a construção colaborativa de conteúdos, suas referências de atuação ainda encontram-se ligadas às ações desenvolvidas pela instituição em sua sede física;

- Museus realmente interativos: em alguns casos, esse tipo de site pode até fazer referências ao museu físico, mas ainda assim apresenta-se como uma nova plataforma de atuação independente das ações desenvolvidas pela instituição em seu perímetro. Seus conteúdos não são uma simples reprodução do que encontramos no museu físico, todavia, constituem-se como um espaço paralelo que privilegia a comunicação e a interação com o usuário. Esse tipo de site costuma apresentar ferramentas de navegação e participação que estimulam a

\footnotetext{
${ }^{20}$ HENRIQUES apud PIACENTE, Maria. Surfs Up_: Museums and the World Wide Web, MA Research Paper, Museum Studies Program, University of Toronto, 1996.

Disponível em http://pt.scribd.com/doc/14342377/Museus-Virtuais, acesso em dezembro de 2010.

${ }_{21}^{2}$ Fundada em 1997, a revista, publicada trimestralmente aborda questões ligadas à educação ligada às práticas interdisciplinares e ao debate cultural.

Disponível em http://www.pedagogika.it/index.php?p=news\&o=ListNews\&reset=1, acesso em janeiro de 2011.
} 
permanência do usuário de forma lúdica, constituindo-se como um ambiente de aprendizagem constante.

Utilizar-se-á, como um dos parâmetros de avaliação e diferenciação entre os sites estudados, essa tipologia criada por Piacente. Acredita-se que, estabelecida a distinção entre Webmuseus e Museus Virtuais, faz-se necessário aprofundar mais os estudos sobre essa última categoria, pois é nela que se enquadram os sites de museus estudados.

Faz-se também necessária essa distinção, uma vez que encontramos, na maioria dos casos, e em alguns aspectos observados para os estudos dos sites em questão, uma tendência em replicar, no Ciberespaço, a imagem do museu reconhecida e decodificada pela maioria dos espectadores, nesse caso, internautas. Como pensar a Internet como uma possibilidade a mais de relacionamento e interação com o público para além dos limites físicos da instituição? Essa é uma das perguntas que essa pesquisa pretende responder.

\subsection{Possibilidades e realidades na Internet}

A utilização das novas ferramentas da informação facilita a aproximação dos museus com seu público e incentiva o aprendizado sobre Arte. Essa é, de certa forma, uma característica que os museus sempre conservaram, a de serem importantes agentes educacionais e culturais. A maioria de nossas referências sobre História, Arte, Cultura, Patrimônio e Civilizações está guardada em suas coleções. E a construção de nosso imaginário coletivo de referências iconográficas, artistas, períodos e movimentos da História da Arte passam pela intenção de um curador ou pesquisador ligado a alguma instituição museológica.

Dessa forma, e pensando em sua função educativa e de formação de público, as primeiras conferências e estudos realizados pelo ICOM a respeito do surgimento das novas tecnologias de informação e como estas podem influenciar a ideia de Museu enquanto agente de reconhecimento e promoção da sociedade tratam das questões relativas ao uso das novas tecnologias como fator de aproximação da relação entre o espectador e a obra e do museu como espaço de difusão do conhecimento, expandindo suas relações com a sociedade.

Nessa perspectiva, em pesquisa realizada com trinta e três museus ${ }^{22}$ de diferentes lugares do mundo para determinar qual a função principal de se manter um site na Internet, aparecem como causas principais: 
1) Promoção-Marketing;

2) Educação;

3) Ampliar o acesso;

4) Informação;

5) Entretenimento;

6) Geração de receita;

7) Presença na rede/atualização

Logo após a primeira conferência realizada em 1991 pelo ICOM, a fim de debater o tema, muitos museus, especialmente na América do Norte e Europa, lançaram suas versões na Internet.

Após essa corrida em torno da tomada do Ciberespaço pelos museus, ainda sem muita clareza quanto aos limites e possibilidades desse novo espaço, começou-se a discutir questões em torno das diretrizes, gestão e avaliação de seus componentes virtuais que iam além das próprias inovações e recursos tecnológicos que eles continham.

Essas questões relativas à ocupação do Ciberespaço vão suscitar mudanças nos sistemas de gestão dos Museus, com o surgimento de uma nova museologia e de novos papéis assumidos pelos agentes de produção de conhecimento. As figuras e os posicionamentos do curador e do crítico são relativizadas à medida que existem várias leituras e possibilidades de interpretação. Mais do que aberta, a obra encontra-se à mercê de todo tipo de comentários que, a partir de agora, podem ser compartilhados, construídos e visualizados por todos na rede.

Mas com que tipo de site de museu estamos nos relacionando?

Qualquer site disponível na Internet requer um mínimo de preocupação no que diz respeito à qualidade da informação publicada, sua interface, usabilidade e acessibilidade e interatividade.

No que diz respeito à navegação, a homepage ou portal - a página inicial de acesso ao site - deve apresentar conteúdos de fácil visualização e elementos que não dificultem a busca por informações mais detalhadas. São eles:

- Nome do site em destaque;

- Identidade visual que permita o reconhecimento e identificação do visitante com o ambiente que ele acessa;

- Menu com links essenciais para acesso rápido às demais informações do site, preferencialmente posicionado no canto esquerdo ou na parte superior da tela;

22 Web Musing: Evaluating Museums on the Web from Learning Theory to Methodology - Archimuse,1999. Disponível em http://www.archimuse.com/mw99/papers/teather/teather.html, acesso em outubro 2010. 
- E-mail e endereço para se comunicar com o internauta;

- Indicação dos responsáveis pelo conteúdo, interação e manutenção do site;

- Datas de criação e atualização;

- Sistema de busca e pesquisas internas que facilitam o acesso a conteúdos específicos dentro do portal;

Esses são alguns componentes gerais que contribuem para o funcionamento de um bom site. Um dos principais desafios para os museus, no entanto, é explorar o potencial inovador e criador do Ciberespaço para além das experiências conseguidas na relação com o museu físico. O visitante virtual tem de ter acesso a uma experiência única e transformadora, que não pode ser repetida fora do ambiente virtual.

Devemos compreender a Internet como um espaço em potencial onde podem ser desafiados os limites do museu tradicional, experimentando novos meios de interpretação e criação de discursos que não estejam mais só focados na imagem ou no objeto.

Se os museus são um conjunto de atividades interligadas como a museologia, pesquisa, conservação e restauro, ação educativa e divulgação, os museus no Ciberespaço podem, além de conter essas funções, atuar e compreender melhor de que forma se dá a verdadeira interação entre os usuários e suas coleções. Partindo das experiências locais, pode-se criar uma rede que conecta pessoas de diferentes contextos e lugares. É o potencial de identificação de narrativas e realidades locais, criado pelos museus, posto em escala global.

Existem muitas maneiras de se avaliar a eficiência e o alcance de um site. Uma delas pode ser pelo número de acessos diários ou pelo tempo de permanência que esse visitante passa conectado a ele. De qualquer modo, imaginar-se-á que uma das principais funções de um Museu de Arte é fornecer informações, estimular a pesquisa e apresentar ao público suas coleções, o mesmo pode-se supor que valha para o espaço virtual. Assim, o principal conteúdo atrativo de um site de museu seria seu banco de dados, ou seja, as informações sobre as obras em sua coleção, como imagens, autor, textos, período, data de criação, movimentos, técnica, etc., e sua eficácia seria medida pelo volume de transferência de dados desse banco para os computadores pessoais.

$\mathrm{Na}$ verdade, o funcionamento e a ampliação dos serviços online relacionados aos museus têm aumentado graças à identificação e a caracterização, no ambiente virtual, do relacionamento entre museu e usuário que se estabelece baseado no reconhecimento de três características:

- A transferência de significados entre o objeto colecionado e a experiência particular do internauta; 
- O contexto social e cultural em que o museu opera;

- As contribuições que o visitante trouxe para o site e seu papel enquanto colaborador na construção de um discurso institucional mais participativo.

Utilizaremos, dessa forma, alguns desses critérios que parecem ter sido de grande relevância quando do aparecimento dos primeiros sites relacionados às instituições museológicas para analisar e comparar, qualitativamente, os conteúdos, recursos, ferramentas e o nível de interação com os usuários, além das discussões atuais em torno da utilização do Ciberespaço como lugar de construção permanente e colaborativa de conhecimento.

\subsection{TATE Online: a quinta Galeria TATE}

Criada em fevereiro de 1998, a plataforma TATE Online (www.tate.org.uk), espaço da TATE construído para habitar o Ciberespaço, inicialmente foi concebida como uma ferramenta de pesquisa sobre conteúdos relacionados à história da arte.

No começo, o design e a interface do site foram criados por uma agência contratada, a Nykris Digital Design, que, junto com uma equipe da própria instituição, era responsável por gerenciar os conteúdos e recursos disponíveis no site. Posteriormente, o desenvolvimento da criação do site deu-se dentro da própria instituição, contando com a colaboração de agências ou colaboradores individuais.

Logo no início, nos três primeiros anos de funcionamento, os arquivos online disponibilizados somavam cerca de 300 horas de áudio e vídeo apresentando importantes conteúdos sobre Artes pensados e construídos por artistas e teóricos, de dentro e fora da instituição.

Nesse período, seu espaço na Internet tornou-se um dos maiores e mais populares sites de arte do mundo, contendo um catálogo com cerca de 25 mil obras digitalizadas pertencentes à Coleção TATE, 14 mil imagens, 2.500 páginas de texto online e um sofisticado sistema de pesquisa ao banco de dados que possibilita ao usuário localizar de forma rápida a informação desejada.

No ano de 2001, a TATE inicia uma parceria com a $\mathbf{B T}^{23}$, British Telecom, que vai assegurar a expansão dos conteúdos do site, dos recursos tecnológicos e de hospedagem.

\footnotetext{
${ }^{23}$ A BT é uma empresa global de serviços de telecomunicações com sede em Londres e que mantém operações em mais de 170 países. Através do seu sistema BT Global Services é uma importante fornecedora de serviços de telecomunicações para clientes empresariais e governamentais em todo o mundo. Disponível em http://www.globalservices.bt.com/AboutusDetailsAction.do/About-us/about-bt-globalservices/param/Record/about_bt_global_services_about_bt_global_services_uk_en-gb/ts/1305725264888, acesso em janeiro de 2011.
} 
Essa parceria vai ser de fundamental importância para a mudança no entendimento e na relação dos usuários com a TATE.

As primeiras ações desenvolvidas pela instituição no campo virtual eram em torno da programação do Ciberespaço como alternativa à visita ao museu ou uma preparação a ela.

Ainda em 2001, como parte das atividades realizadas em comemoração ao Centenário de Desenvolvimento da TATE, foi lançado um novo programa de navegação que permitia ao usuário viajar por sua coleção. Chamado de Explore TATE Britain, esse programa permitia ao visitante interagir com a exposição em cartaz no primeiro andar da TATE Britain. Uma descrição de cada uma das obras expostas e um panorama histórico e social do conteúdo em cartaz também foram disponibilizados no site, além de materiais de áudio e vídeo que traziam novas possibilidades de leitura e utilização de recursos que o espaço virtual era capaz de oferecer.

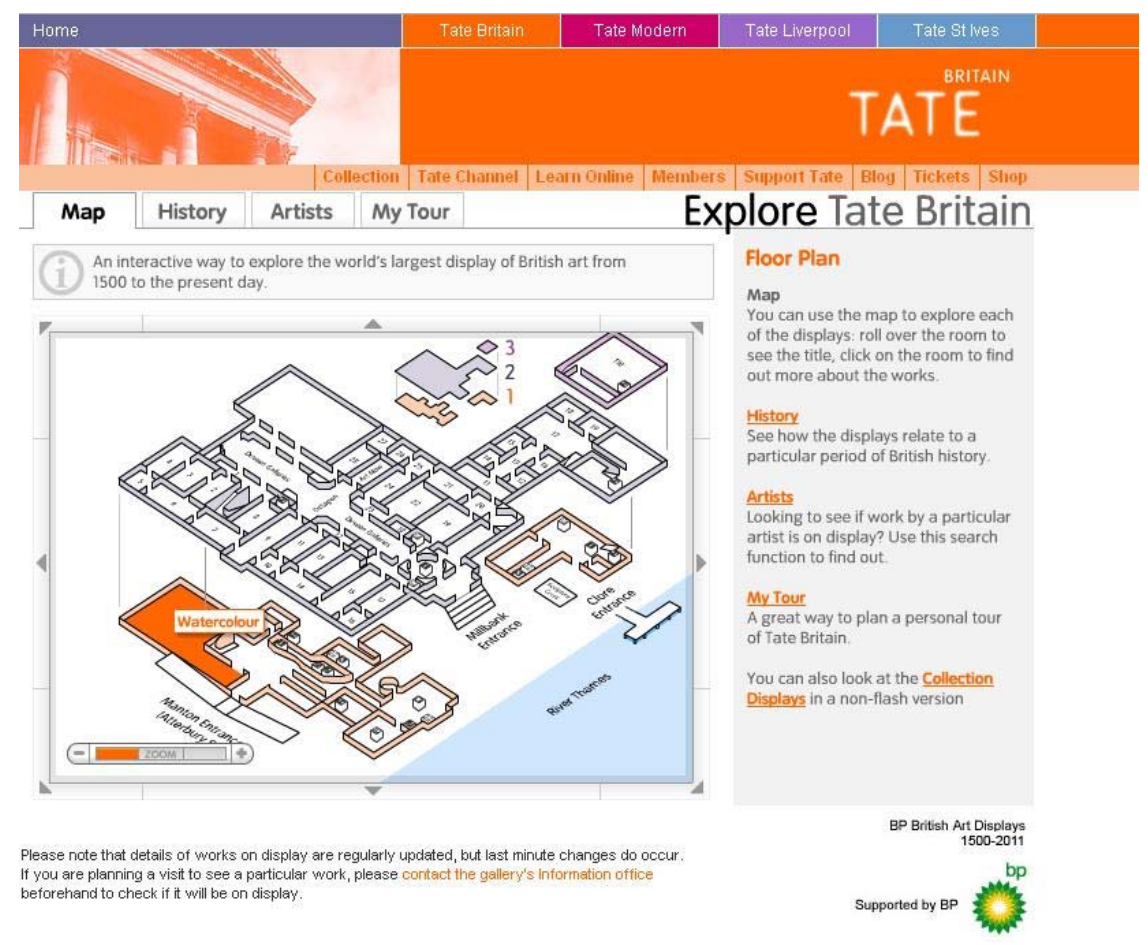

Imagem 1 - Detalhe da página Explore Tate Britain

Essa nova apresentação da TATE Online oferecia àqueles que não tinham a possibilidade de estar na TATE Britain a oportunidade de dialogar com as obras em exibição, e, aqueles que já haviam visitado a galeria, poderiam encontrar no site informações adicionais sobre os trabalhos, rever e repensar, por meio do ambiente virtual, o que fora visto no espaço museológico.

Com o passar do tempo, muitas foram as preocupações da TATE em torno da expansão e alcance de suas ações tendo como foco seu público virtual. Mas o uso de 
recursos e inovações tecnológicas não se deu apenas no site, eles, aos poucos, fizeram parte do dia a dia do museu.

Essa ampliação no uso de dispositivos que permitiam ao visitante ampliar sua experiência junto às obras aumentando a compreensão das mesmas estimulava o retorno do visitante ao museu.

Dessa forma, além de explorar a aproximação natural dos visitantes com as novas tecnologias trazendo o espaço museológico para dentro do computador, a TATE amplia seu alcance ao se relacionar, por intermédio da TATE Online, com os usuários que não tem a possibilidade de visitar o espaço físico do museu; inaugura, assim, outra forma de se comunicar com o visitante e propicia um novo tipo de público, aquele que pensa, escreve, lê, ouve e se comporta dentro das regras do Ciberespaço.

Em pouco tempo, a plataforma TATE Online se tornou um dos principais canais de comunicação do público com a instituição, e é através dele que o usuário recebe a maioria das informações ligadas ao funcionamento e às diretrizes da TATE.

Em pesquisa realizada em 2005, na ocasião da comemoração dos cinco anos da TATE Modern, verificou-se que aproximadamente $50 \%$ dos ingressos vendidos antecipadamente para as exposições e eventos realizados nas quatro sedes da TATE eram feitos online. Além disso, mais de 60.000 newsletters (boletins informativos sobre a programação e o funcionamento das quatro galerias) eram enviados mensalmente pela equipe da Tate Online.

A pesquisa observou ainda, o crescimento no número de acessos ao site, como mostra a tabela abaixo:

Número de visitantes da TATE Online no período de 2002 a $2005^{24}$ :

\begin{tabular}{|c|c|}
\hline PERÍODO & ACESSOS \\
\hline JANEIRO-DEZEMBRO 2002 & 898.059 visitantes \\
\hline JANEIRO-DEZEMBRO 2003 & 2.644 .344 visitantes \\
\hline JANEIRO-DEZEMBRO 2004 & 4.748 .798 visitantes \\
\hline JANEIRO-DEZEMBRO 2005 & 7.000 .000 visitantes \\
\hline
\end{tabular}

Ao final de 2005, a média de acessos diários ao site era de 8.000, e a plataforma Tate Online foi se constituindo não apenas como um dispositivo de comunicação e informação sobre as atividades e o funcionamento da instituição, mas passou a ser uma importante ferramenta de educação, formação e preparação do espectador para a experiência da visita ao Museu.

\footnotetext{
${ }^{24}$ Pesquisa retirada do catálogo Tate Modern: The First Five Years. London: Tate Publishing, 2005.
} 
O modo como ela se comunica, quais conteúdos e qual o discurso sobre Arte ela veicula, de quais ferramentas e dispositivos se utiliza para estabelecer a aproximação com público e, possivelmente, estimular sua ida ao museu, são questões emergentes que permeiam a sociedade da comunicação em que estamos inseridos.

Diante disso, não foram só os visitantes do museu ou os usuários do site que modificaram suas leituras e percepções sobre o que é, e qual é o espaço da Arte hoje. A própria TATE Online começa a repensar seu relacionamento com os usuários do Ciberespaço no sentido de considerar o ambiente virtual como uma réplica ou preparação para o que pode ser encontrado no espaço expositivo, e começa a entender o ambiente virtual como espaço em potencial para o desenvolvimento de ações que acontecem na e para a Internet. Ampliam o uso de ferramentas de vídeo, som e a criação de blogs com comentários de artistas e usuários, valorizando cada vez mais a participação do visitante na colaboração e criação de conteúdos em parceria com a própria instituição.

É nesse sentido que a TATE vai desenvolver suas ações, estabelecendo e fortalecendo as parcerias criadas com artistas, empresas e outras instituições culturais, ampliando o entendimento do seu site como a quinta Galeria TATE.

\subsection{0 [novo] Projeto TATE Online}

Atualmente, a principal função da plataforma Online é ajudar a cumprir a missão da TATE para promover o entendimento e a fruição do público para as obras de arte britânica e internacional.

A criação da TATE segue o mesmo padrão de outros museus, ao longo dos séculos XIX e XX, cujos idealizadores eram grandes empresários, industriais ou personalidades de prestígio e influência no campo das Artes e da Cultura.

Em 1889, Henry Tate, poderoso empresário do setor açucareiro, decidiu oferecer sua coleção de 65 obras de arte britânica à nação. Diante da recusa da National Gallery em aceitá-la, iniciou-se um acordo com o governo britânico que decidiu acolher a proposta de Henry Tate, doando um terreno para a construção do novo prédio. Hoje, a coleção TATE tem cerca de 68 mil obras que estão divididas em quatro galerias: TATE Britain, Modern, Liverpool e St. Ives.

Nesse sentido, a TATE Online tem uma posição privilegiada para alcançar essa missão, conquistando novos usuários e aproximando-os da instituição.

O rápido desenvolvimento das novas tecnologias e conexões em alta velocidade, além da mobilidade dos serviços oferecidos na rede promoveu mudanças no modo de se relacionar e comunicar com os bens culturais de nossa sociedade. 
Entretanto, os museus e as instituições culturais de uma forma geral demoraram a perceber essas modificações e suas respostas ainda têm sido lentas para atender a essa nova demanda de espectadores online.

Na contramão, a TATE Online é hoje reconhecida como um dos melhores sites de museus do mundo. Esta reputação é, em grande parte construída, devido ao extenso conteúdo e informação sobre Arte que tem sido produzido e publicado no site, especialmente a partir de 2001.

Essas ações levaram o entendimento do site não apenas como um canal para a publicação de conteúdos sobre a TATE, mas também como uma plataforma interativa para o relacionamento com o público.

Percebeu-se, então, que era necessária uma reformulação do site a fim de atender às demandas e estratégias de desenvolvimento da própria instituição, cada vez mais centradas em sua aproximação com o usuário.

As ações em torno da ampliação do site, que fazem parte das estratégias que integram as metas para a TATE até 2015 concentram-se na ampliação e consolidação da marca e dos valores a ela associados, estratégias para captação de novos públicos e novas formas de aprendizagem, além de repensar o relacionamento com o visitante, especialmente o público presente no ambiente virtual.

A principal ambição em torno da reformulação do site é torná-lo o mais atraente e completo site sobre Arte, além de acessível aos usuários onde quer que eles estejam, em conexão móvel ou fixa, de alta ou baixa velocidade, a fim de promover ao visitante a sensação de estar entrando na quinta galeria TATE, espaço em que ele vai encontrar praticamente tudo que o esperaria de um ambiente museológico, de informações sobre pesquisa e conservação de obras, a programas educativos e para angariação de fundos.

Foram então traçadas dez ações principais para garantir a manutenção e a ampliação das metas.

\subsubsection{Princípios para o desenvolvimento da plataforma TATE Online ${ }^{25}$}

Foi identificado e elaborado um plano de metas composto de dez ações que visam melhorar a relação do museu com o usuário online explorando os potenciais do site e o desenvolvimento do Ciberespaço como lugar de inclusão e compartilhamento de dados, ações e operações sitematizadas. São elas:

${ }^{25}$ Disponível em http://www.tate.org.uk/research/tateresearch/tatepapers/10spring/stack.shtm, acesso em abril de 2010. 


\section{Fácil navegação.}

A estrutura do site e da navegação deve ajudar e responder às expectativas do visitante promovendo sua autonomia e interação com os conteúdos;

\section{O site é uma plataforma para a publicação e a interação.}

Através da publicação de cursos e conteúdos online pretende-se aprofundar a experiência do visitante criando um ambiente para a discussão, debate e participação;

\section{O site deve ser constantemente ativado.}

Por meio da criação de blogs, artigos e recursos multimídia, busca-se encontrar novas maneiras de compartilhar os conhecimentos e ideias de artistas, críticos, curadores e pessoas que trabalham na instituição às dos usuários;

\section{Conteúdos promocionais e de participação do usuário devem estar perfeitamente integrados ao site.}

Os recursos de criação colaborativa como blogs, comentários de usuários e tópicos de discussão devem ser apresentados junto com o conteúdo principal e não acessados fora do portal, assim como as informações sobre a loja virtual e patrocinadores;

\section{Páginas interligadas e independentes entre si.}

A maioria dos visitantes online entra no site a partir de um software de busca ou link de entrada presente em outros sites, dessa forma, cada página deve ter o seu contexto claro através da navegação e oferecer links para conteúdos relacionados;

\section{Gestão de conteúdos.}

As preocupações em torno da distribuição, publicação, consumo, cooperação, criação e compartilhamento de informações por intermédio do site devem ser gerenciadas pela própria instituição que além dos conteúdos produzidos por ele, deve administrar as publicações dos usuários;

\section{Os conteúdos online devem ser livres e compartilhados.}

Os usuários devem ser livres para aproveitar e redistribuir os conteúdos do site promovendo uma maior utilização dos mesmos; 


\section{Estar presente no mesmo espaço em que o usuário.}

Com o uso de mídias sociais, sites de terceiros e novas plataformas móveis, pode-se atingir novos públicos e interagir nos espaços online por onde ele navega;

\section{Personalizar a experiência do visitante.}

Ao permitir aos usuários personalizar a sua visita online na plataforma TATE, buscase melhorar a sua experiência, ser capaz de se comunicar de forma mais eficaz, e atender às suas necessidades diversificadas;

\section{O site deve ser autossustentável.}

Para facilitar o crescimento do site, deve-se escalonar os custos com manutenção e direitos autorais relacionados aos conteúdos publicados.

Essas ações foram elaboradas e formuladas a partir da discussão entre funcionários da própria instituição e colaboradores, e estão de acordo com o plano de estratégias da TATE para 2015.

Devido à rápida evolução e às constantes mudanças ocorridas na área das tecnologias da informação, foi proposto que as estratégias para desenvolvimento online sejam revistas a cada dois anos.

Essa estratégia responde às principais iniciativas internas e às futuras ações em torno no desenvolvimento dos programas de aprendizagem online, incluindo:

- Missão TATE

- Visão TATE 2015 e estratégias até 2012

- Revisão da marca TATE

- Estratégias para captação de público

- Estratégias de publicação digital

\subsubsection{Presença constante na rede}

A velocidade na transformação com que as informações entram na rede gera também mudanças no perfil dos usuários conectados.

O aparecimento das redes sociais alterou definitivamente a relação dos usuários com a rede. Surgem usuários com perfis cada vez mais colaborativos, que se transformam em autores, editores, críticos e leitores ativos, e que esperam que os sites por onde navegam sejam cada vez mais interativos. 
A criação de hardwares móveis que permitem conexão permanente à Internet, onde quer que os usuários estejam, amplia seu alcance e potencial de uso. As informações circulam na rede cada vez mais de forma ágil e podem ser facilmente compartilhadas e distribuídas em diversos sites.

Dessa forma, uma das metas da plataforma TATE Online é centrar seu serviço nas necessidades dos usuários. Seja na criação de blogs, comunidades virtuais ou espaços dentro do site que estimulam o feedback e a interação entre os internautas e a própria instituição, seja no desenvolvimento cada vez mais elaborado de conteúdos específicos para o site, que devem atender desde crianças até adultos, ou pelo estímulo à incorporação de informações traduzidas em outros idiomas, substituição do material impresso pelo digital, e criação de ferramentas de edição e construção de interfaces que aproximam os usuários do site, o espaço virtual da TATE é pensado como independente das outras quatro galerias, que pode, é claro, somar-se a elas, mas que tem um funcionamento e um público próprios, que possivelmente não será o que frequenta a sede física do Museu, mas que, independente disso, é capaz de pensar e discutir sobre Arte. Através da TATE Online a instituição quer chegar onde o público está, seja nos espaços das redes sociais, nos fóruns e comunidades de discussão ou em qualquer outro lugar do Ciberespaço.

Para garantir essa meta, uma importante ferramenta de interação com o usuário foi criada.

Lançada em setembro de 2006, em parceria com a BT, a TATE Media, é um canal de comunicação que oferece conteúdos até então não disponibilizados ao público. É também o espaço onde acontece de forma mais efetiva a comunicação e interação com os internautas, o lugar em que eles podem interferir e escolher o modo como querem interagir com o Museu.

Os conteúdos disponibilizados são encomendados ou apresentados de forma exclusiva nesse espaço, ou seja, o visitante não teria acesso a eles de outra forma. A TATE Media opera em diversas plataformas de difusão, como produção de conteúdos digitais em vídeo, áudio, textos e imagens, incluindo novas visões e leituras do próprio acervo da instituição, contando com a colaboração de artistas e empresas de comunicação.

Mais uma vez, a parceria com a BT foi de fundamental importância para garantir o sucesso e manutenção do projeto. A empresa foi responsável pela hospedagem, design e suporte técnico do projeto, garantindo sua expansão e acesso em qualquer parte do mundo, seguindo o princípio de arte para todos, estabelecido no início da parceria, em 2001. A associação destas duas empresas tem, como objetivo principal, ampliar o acesso à Arte e à fruição das obras e atingir um novo público.

As estratégias lançadas para a ampliação dos serviços relacionados à TATE Media tem como objetivos a criação de experiências mais profundas em torno da relação com as 
obras da coleção; financiamento para a produção de conteúdos; estimular a participação dos usuários em comunidades virtuais e espaços para registrar seus comentários; estimular a interação através da produção de conteúdos feitos pelos usuários; apresentar, de forma clara e em destaque, que as informações sobre Arte, artistas e os visitantes do site devem se destacar das estruturas e informações institucionais; e mostrar de forma clara e diferenciada, a opinião dos internautas e o posicionamento do museu, garantindo a manutenção das práticas colaborativas da Internet, mas ressaltando a opinião da instituição sobre determinado assunto ou tema.

Outro projeto lançado para habitar a plataforma Online e que ressalta a importância em estabelecer parcerias e estar presente na rede é o Matters in Media Art $^{26}$.

Trata-se de um projeto lançado em 2003 para fornecer informações sobre a preservação e conservação de obras de arte criadas em suportes diferenciados como vídeo, áudio, filmes e mídias digitais. Através de um conselho de curadores, restauradores e gestores técnicos de quatro instituições, New Art Trust ${ }^{27}$, MoMA $^{28}$, SFMOMA ${ }^{29}$ e TATE, são pensadas, de forma colaborativa, estratégias e soluções para a melhor maneira de guardar, conservar e restaurar essas obras, bem como a elaboração de pesquisas e a criação de conteúdos que fornecem um panorama de como a instalação destes trabalhos exige novas competências e novas áreas de colaboração entre museus, que vão além das práticas museológicas tradicionais.

\subsection{Estratégias de comunicação e aproximação com o usuário}

A principal estratégia da TATE para aumentar sua aproximação com o usuário e, dessa forma, estimular e aumentar a quantidade de visitantes ao site é focar seu funcionamento e suas estratégias de ação nas necessidades e particularidades de cada um, tornando a experiência de navegação no site cada vez mais centrada e personalizada em quem interage.

\footnotetext{
${ }^{26}$ Disponível em http://www.tate.org.uk/research/tateresearch/majorprojects/mediamatters/use.htm, acesso em abril de 2011.

${ }^{27}$ Fundada em 1997 por Pamela e Richard Kramlich, a instituição tem como missão promover a divulgação, preservação e conservação das obras realizadas em novas mídias como o vídeo e a Internet.

Disponível em http://www.tate.org.uk/research/tateresearch/majorprojects/mediamatters/newarttrust.htm, acesso em abril de 2011.

${ }^{28}$ Fundado em 1929, o Museu de Arte Moderna de Nova York é um dos mais importantes museus de arte moderna e contemporânea. Desenvolve ações de preservação, conservação, pesquisa, publicações e um vasto programa de exposição. Disponível em http://www.moma.org/about/index, acesso em abril de 2011.

${ }^{29}$ Fundado em 1935, o Museu de Arte Moderna de São Francisco foi o primeiro museu na costa oeste americana dedicado à arte moderna e contemporânea. Hoje, possui uma coleção com cerca de 26 mil obras, fotografias e objetos de design. Disponível em http://www.sfmoma.org/about/about_sfmoma\#ixzz1XCxK95R1, acesso em abril de 2011.
} 
Foi então detectada a necessidade de promover uma reformulação no seu design e na interface, tendo como destaque os espaços para as ferramentas de pesquisa e de navegação.

Da mesma forma, o projeto gráfico deve ser limpo, de fácil navegação, com menus atrativos e que reduzam o tempo do usuário em acessar determinada informação, os textos devem apresentar ligações para assuntos mais aprofundados dentro do site e ligações externas com outros espaços como redes sociais, blogs e sites institucionais.

As imagens de obras e o conteúdo multimídia devem se destacar no corpo do texto promovendo uma estrutura organizada de forma a facilitar a diferenciação entre conteúdo, design e funcionalidade.

Uma das principais mudanças pretendidas é a criação de um espaço para a participação dos usuários. Com a criação de um login, o visitante pode conectar-se diretamente com o site e administrar e gerenciar suas preferências, podendo configurar suas interfaces, seu boletim de e-mails, acompanhar o desenvolvimento de cursos online, configurar sua própria coleção de obras, além de poder acessar diretamente a loja virtual e os espaços para comentários, fóruns de discussão, etc. Esses recursos fazem com que o visitante sinta-se familiarizado com o site e reconheça nele um espaço em potencial para a ação e a reflexão sobre os assuntos ligados à Arte, além de aproximar a instituição do público internauta, conhecendo suas preferências, número de vezes e tempo que passa conectado, assuntos e temas que mais lhe interessam, podendo, com essas informações, estabelecer uma comunicação mais direcionada e centrada nos seus interesses.

Como foi visto, a ideia é evidenciar a informação e os espaços para a interatividade e a criação de conteúdos colaborativos, deixando em segundo plano as estruturas internas e de funcionamento, permitindo que o usuário tenha autonomia na navegação e na busca por informações que mais lhe interessem.

Houve, então, uma redivisão das estruturas e na forma de apresentação dos conteúdos dentro do portal em cinco áreas principais e diferenciadas:

- Informação atualizada sobre as exposições de cada uma das quatro galerias. As exposições em cartaz nas unidades da TATE são mostradas em um banner animado em destaque na parte superior da tela;

- Coleção online. Informação sobre artistas, obras, escolas, períodos e movimentos artísticos, além de textos de curadores e pesquisadores da área;

- Programas e Recursos Online. Destaque para os programas e ferramentas de interação da TATE com o usuário como o TATE Channel e o Intermedia Art, que disponibilizam conteúdos em áudio e vídeo para armazenamento; 


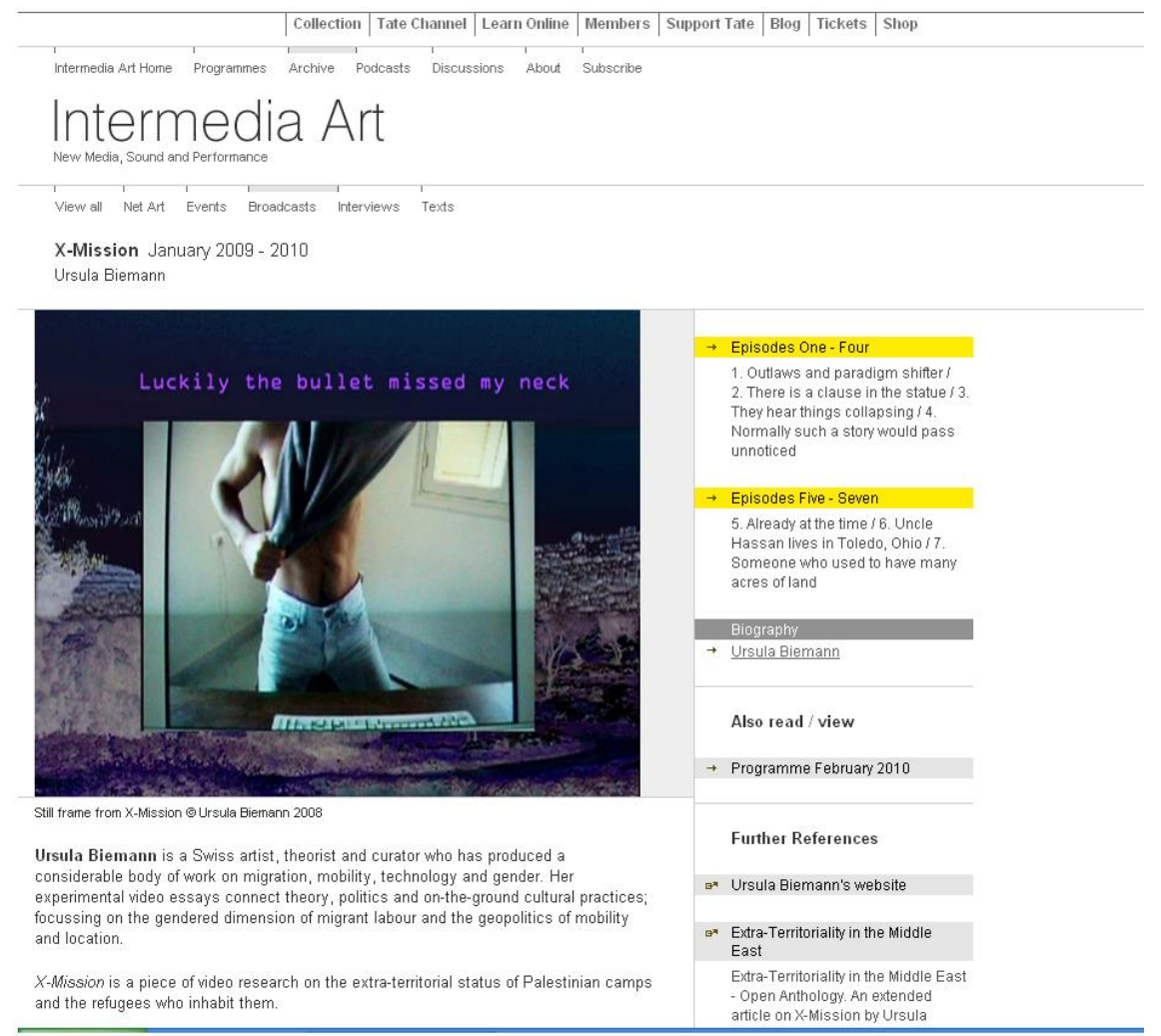

Imagem 2 - Detalhe da página TATE Intermedia Art

- Link direto com a revista TATEETC. que apresenta material de pesquisa e conteúdo sobre arte produzido pelos pesquisadores do museu e convidados. Esse conteúdo faz parte de uma publicação impressa trimestralmente e que tem sua versão digitalizada e disponibilizada no portal da instituição. Além da revista, a TATE produz anualmente o TATE Papers com artigos relacionados à comunidade museológica e a assuntos de Arte em geral;

- Destaque para os recursos de aprendizagem online como o TATE Kids, Young TATE, Schools \& Teachers e Learn Online; divididos por faixas etárias, temas e categorias de interesse.

Outra preocupação da plataforma TATE Online é valorizar e aproximar o internauta das próprias obras presentes no acervo da TATE. Para isso, são valorizadas as ações ligadas à pesquisa das obras da coleção promovendo uma posição de destaque na página inicial do site e expandindo essas ações para as redes sociais e os boletins informativos via e-mail onde a TATE se faz presente.

Ao estabelecer a presença constante na rede e não só no site oficial da instituição, a TATE consegue atingir um número maior de usuários e um público que, talvez, nem fosse seu foco principal. Dessa forma, novas relações entre as obras de arte podem ser 
estabelecidas, e os visitantes, de diferentes níveis de conhecimento e interação, podem estabelecer suas perspectivas ao explorar a coleção online.

Há uma preocupação constante em tratar o site como um espaço em potencial para o conhecimento e o aprendizado sobre Arte. - retirar esse parágrafo todo.

\subsection{Aprender Online}

Muitos são os recursos e ferramentas disponibilizados no site da TATE que permitem a atualização constante do usuário e o aprendizado permanente através da página do museu.

As ações tem como foco o desenvolvimento da criatividade, a interação social, de habilidades e participações que fazem com que os usuários sejam capazes de gerar seus próprios conteúdos e se corresponderem em comunidades de interesse.

Os recursos são divididos em quatro áreas principais, cada uma correspondente à determinada faixa etária.

São elas:

- TATE Kids: enfoca o aprender fazendo. Promove a criatividade e a participação das crianças por meio da criação de uma comunidade online em que elas podem selecionar suas próprias obras, comentar e modificar as imagens em exposição. Há também uma variedade de jogos interativos, com foco na coleção TATE, que tem como objetivo estimular a participação das crianças à pesquisa e ao interesse pela arte, contribuindo, assim, para a formação de público e à busca pelo conhecimento relacionado às Artes em geral;

- Young TATE: comunidade online voltada para o público adolescente. Nela, os usuários podem desenvolver seu potencial criativo e compartilhar pensamentos e experiências. Além de criar e compartilhar os próprios trabalhos em galerias virtuais, os jovens encontram informações sobre como seguir carreira na área artística, podendo inclusive interagir em todos os espaços das mídias sociais em que a TATE está; 


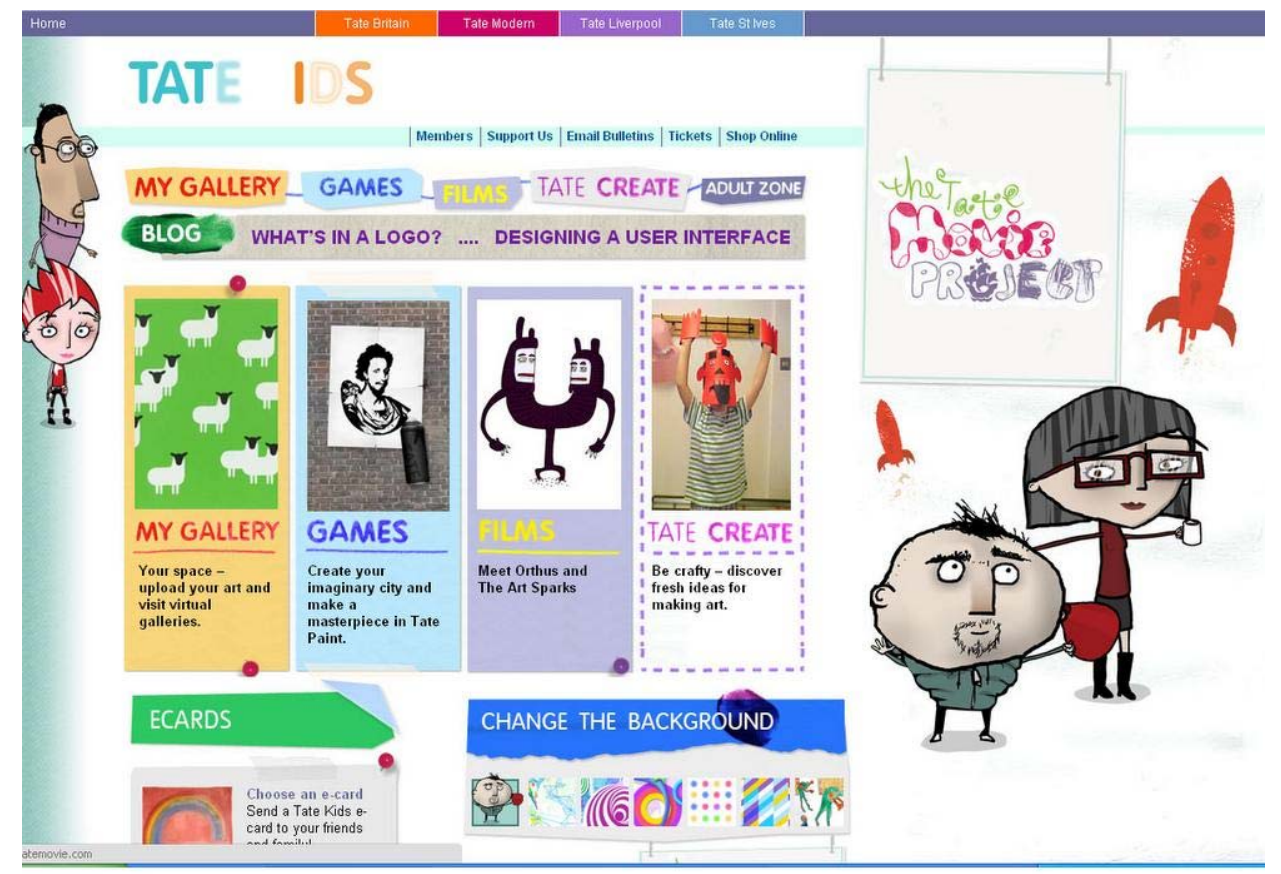

Imagem 3 - Detalhe da página TATE Kids

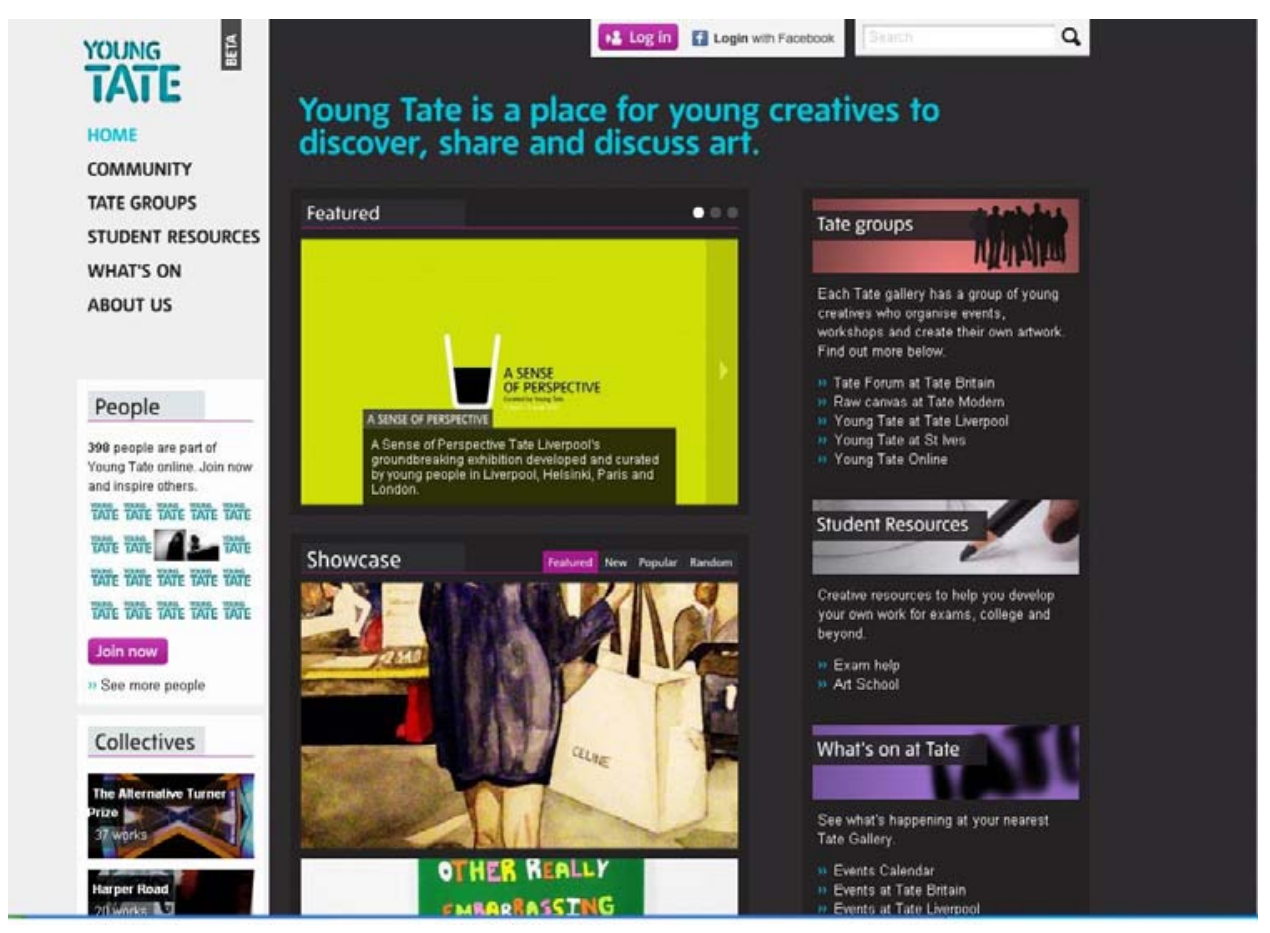

Imagem 4 - Detalhe da página Young TATE

- Schools \& Teachers: em parceria com escolas e instituições de ensino, a TATE desenvolve projetos que utilizam a Internet como mídia colaborativa e estimulam a participação de alunos e professores a visitarem o site da instituição, onde são disponibilizados pacotes de ensino para download, galeria de imagens e obras do acervo, lousa virtual e outros recursos de interação e participação online; 


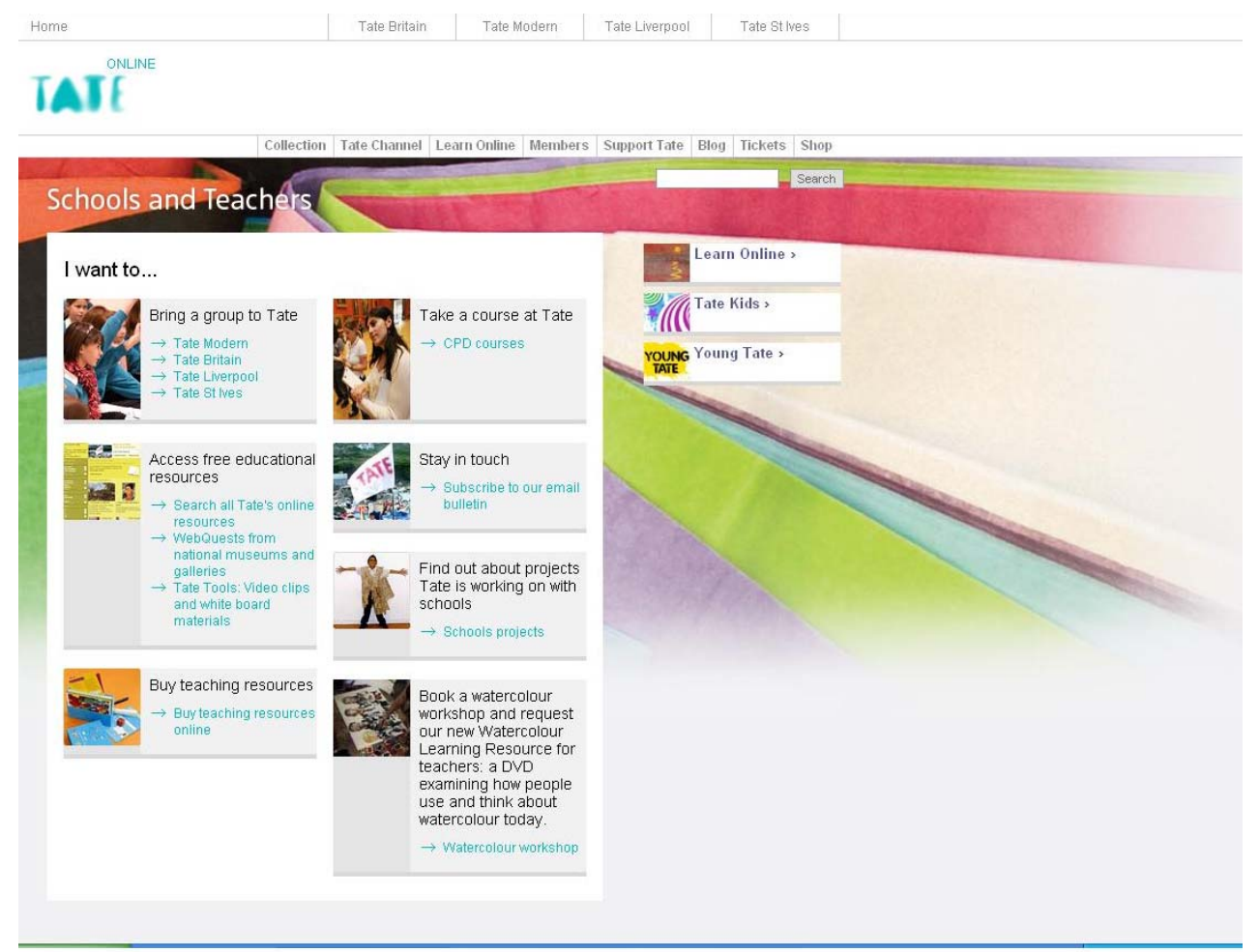

Imagem 5 - Detalhe da página TATE Schools and Teachers

- Learn Online: comunidade dirigida ao público interessado em artes. Seus recursos permitem uma pesquisa aprofundada no banco de dados da instituição, categorizada por artistas, assunto, período, etc. Há também um espaço para a criação e publicação de obras criadas em mídias digitais. O site atua como uma galeria em que todos os usuários podem inserir e comentar as obras online. Um importante recurso é a possibilidade de realizar cursos relacionados às técnicas e práticas artísticas via Internet. 


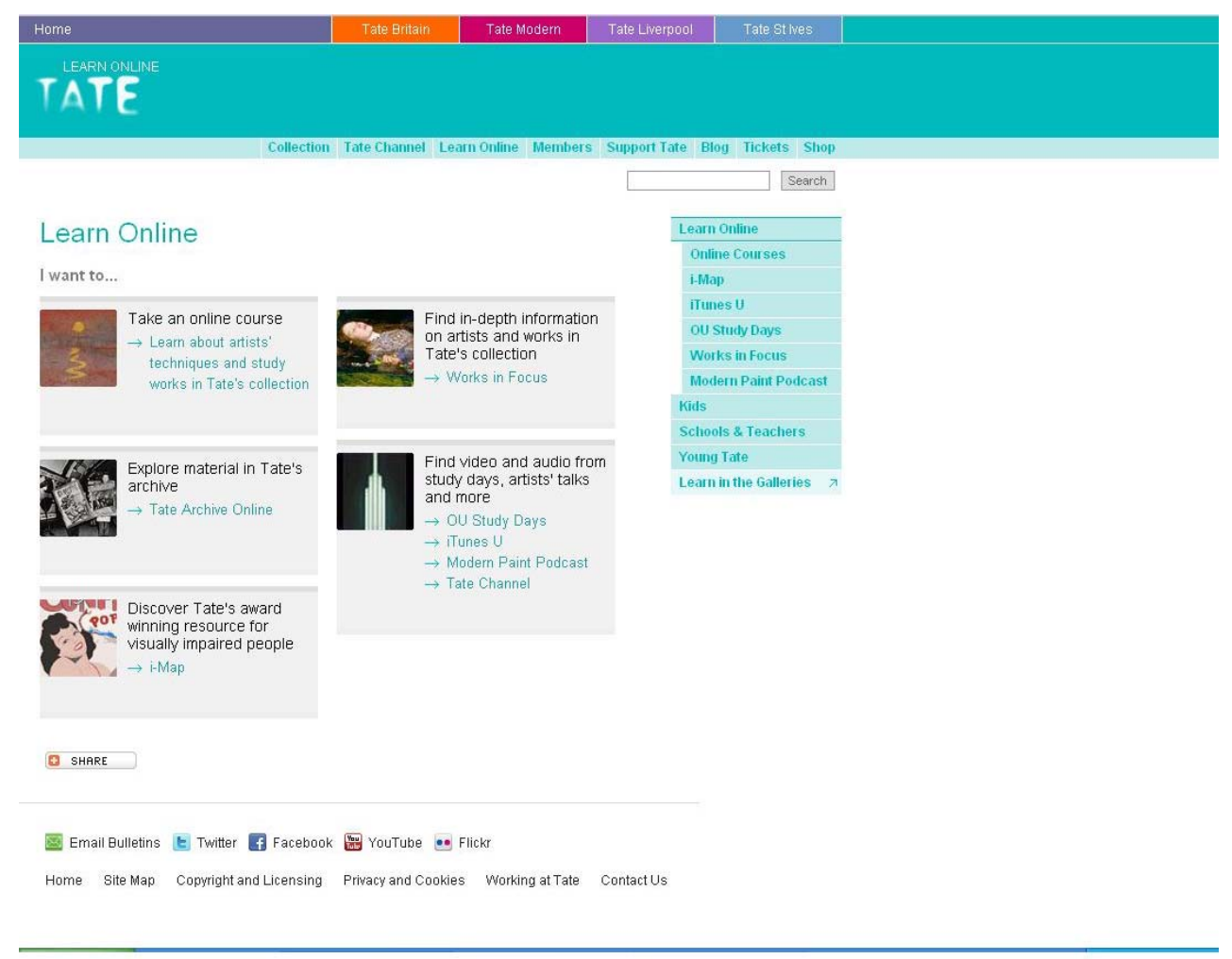

Imagem 6 - Detalhe da página TATE Learn Online

Além desses programas, a TATE desenvolve ainda um projeto em parceria com a Unilever, o Unilever Series. Trata-se de um projeto anual que convida um artista para fazer uma obra de arte especialmente desenvolvida para o Turbine Hall, espaço reservado às instalações e site specific dentro da Tate Modern, criando algumas das esculturas mais inovadoras e importantes dos últimos anos, e já contou com a participação de artistas como Louise Bourgeois, Anish Kapoor, Brune Nauman, Rachel Whiteread e Carsten Höller.

O projeto deu origem à série TURBINEGENERATION ${ }^{30}$, realizada em parceria com as escolas e faculdades de todo mundo, que promove a aproximação entre as galerias e artistas internacionais e a divulgação de trabalhos de arte contemporânea. Entre 2009 e 2010, 16 países estavam envolvidos no programa, e a meta para 2012 é que essa rede alcance escolas e galerias em mais de 30 países.

As ações ligadas à pesquisa e bolsas de estudo realizadas em torno da coleção da TATE também são informadas e se tornam disponíveis online.

Essa é uma das preocupações principais em torno do site; apoiar e publicar os projetos realizados em torno da investigação e conhecimento da coleção e dos projetos produzidos pelos curadores e pelo departamento de pesquisa do museu.

\footnotetext{
${ }^{30}$ Disponível em http://turbinegeneration.tate.org.uk/content/depth, acesso em maio de 2011.
} 
Além dessas ações, há a intenção de criar uma rede de acadêmicos e estudiosos ligados às instituições culturais de todo o mundo, a fim de fornecer e compartilhar informações relacionadas à gestão, criação, desenvolvimento e produção de projetos culturais.

No que diz respeito à produção de conteúdos, o site conta ainda com duas seções onde ficam armazenados os relatórios produzidos pela instituição a cada dois anos, o TATE Reports, que contém informações sobre o funcionamento das quatro galerias, plano de exposições, programas educativos, número de atendimentos, parcerias com escolas, universidades e instituições, novas aquisições e doações, pesquisas de satisfação, programas de financiamento, enfim, todo tipo de informação produzida no período de dois anos é disponibilizada ao público através do site; e o TATE Papers, área do site destinada a exibir a produção de conteúdo e pesquisa realizada pelo museu. O TATE Papers pretende refletir sobre a pesquisa acadêmica realizada na TATE e publicar esse material que é de grande utilidade para a comunidade acadêmica e os leitores em geral. A publicação foi lançada em 2004 e também é realizada duas vezes por ano.

Os artigos são escritos pela equipe TATE, colaboradores associados às atividades do museu (palestrantes, críticos e pesquisadores convidados), e por autores que escreveram textos relativos aos programas atendidos pela instituição (Arte britânica desde os anos 1500 e Arte Moderna internacional). As áreas temáticas incluem a História da Arte e Teoria da cultura visual, e todos os aspectos relacionados com os estudos do museu, incluindo as ações educativas, com o objetivo de oferecer informações e conhecimentos de interesse para a comunidade museológica. 


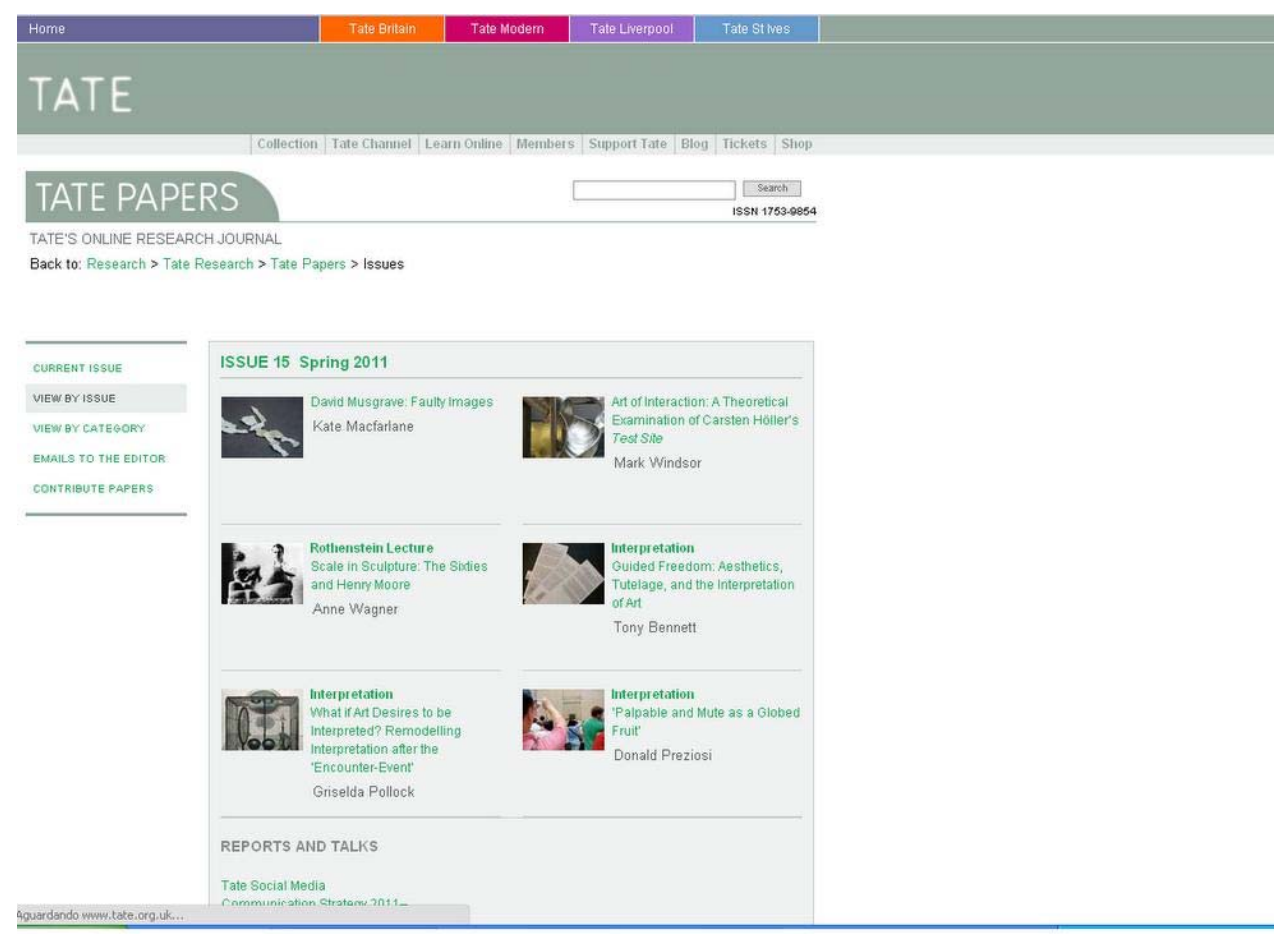

Imagem 7 - Detalhe da página TATE Papers

Além do acesso rápido a esses programas desenvolvidos pela TATE, o usuário também encontra no portal um atalho para a página da TATEETC. A TATEETC. é uma publicação lançada trimestralmente pela instituição. Originalmente concebida para impressão comum, em papel, desde 2004 passou a ter sua versão online disponibilizada integralmente no site do museu. Trata-se de uma publicação especializada em Artes Visuais, com foco nos artistas britânicos. A revista traz artigos escritos por pesquisadores da instituição ou críticos convidados, relacionados ao assunto em cartaz nas exposições das quatro galerias da TATE.

As questões relacionadas à revista, seus conteúdos e a importância de se manter um espaço ativo para a opinião de pesquisadores e profissionais da área dentro do portal serão tratados no capítulo seguinte.

\subsection{Síntese do funcionamento da TATE Online}

Podemos definir o funcionamento do site da TATE em quatro estruturas principais que se correspondem e estão organizados de forma a promover as funções de distribuir conteúdos para um público cada vez mais amplo, relacionar-se com esse usuário de forma mais compartilhada e propagar a missão e a marca TATE dentro do Ciberespaço. 


\section{Portal (Página principal de acesso ao site)}

A página inicial do site conta com uma síntese das informações principais, de fácil acesso e navegabilidade. O usuário encontra menus bem definidos, separados por cores, que o levam para cada uma das quatro galerias da TATE ou para os demais programas online. Nesse espaço também é possível modificar o idioma de apresentação de algumas das atividades e do serviço do museu, embora grande parte do conteúdo produzido para o site, como arquivos de áudio, vídeo e conteúdos em texto esteja disponível apenas em inglês.

Dentro do portal, cada uma das galerias, TATE Britain, TATE Modern, TATE Liverpool e TATE St. Ives, têm suas próprias páginas que funcionam de forma independente. Nelas, além das informações sobre serviços e programas oferecidos, há espaço para investigações sobre a coleção e aprofundamento em determinados temas e recortes curatoriais. Nessas páginas as informações sobre as galerias são individualizadas em relação aos demais conteúdos do portal, permitindo ao usuário o acesso rápido a temas e detalhes que sejam de seu interesse e que ele já tenha a intenção de buscar dentro do site.

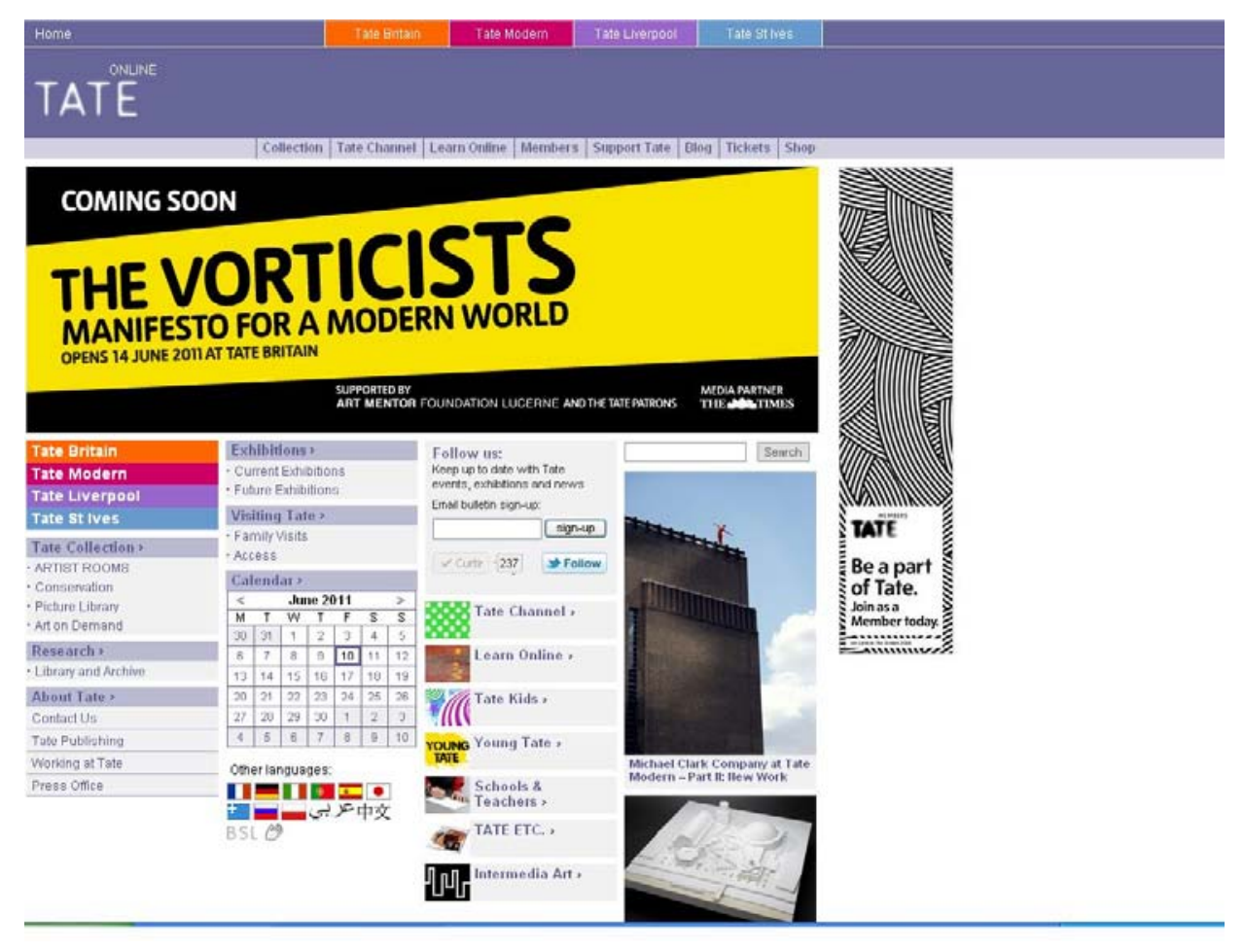

Imagem 8 - Detalhe do Portal TATE Online

Vale a pena observar a quantidade e diversidade de idiomas em que as informações principais, como um breve release sobre as coleções das quatro galerias, horários de funcionamento e endereço, exposições em cartaz e atividades complementares como café, restaurante e lojas, são oferecidas. Encontramos tradução para os 
seguintes idiomas: francês, alemão, italiano, português, espanhol, japonês, grego, russo, polonês, árabe, chinês e a língua britânica de sinais.

\section{Notícias/informações sobre as galerias}

Orientações sobre o funcionamento das galerias e informações constantemente atualizadas sobre as exposições em cartaz e atividades especiais realizadas nas galerias têm posição de destaque na página do museu. Normalmente funcionam como um resumo do que o usuário vai encontrar ao navegar pelas páginas do portal;

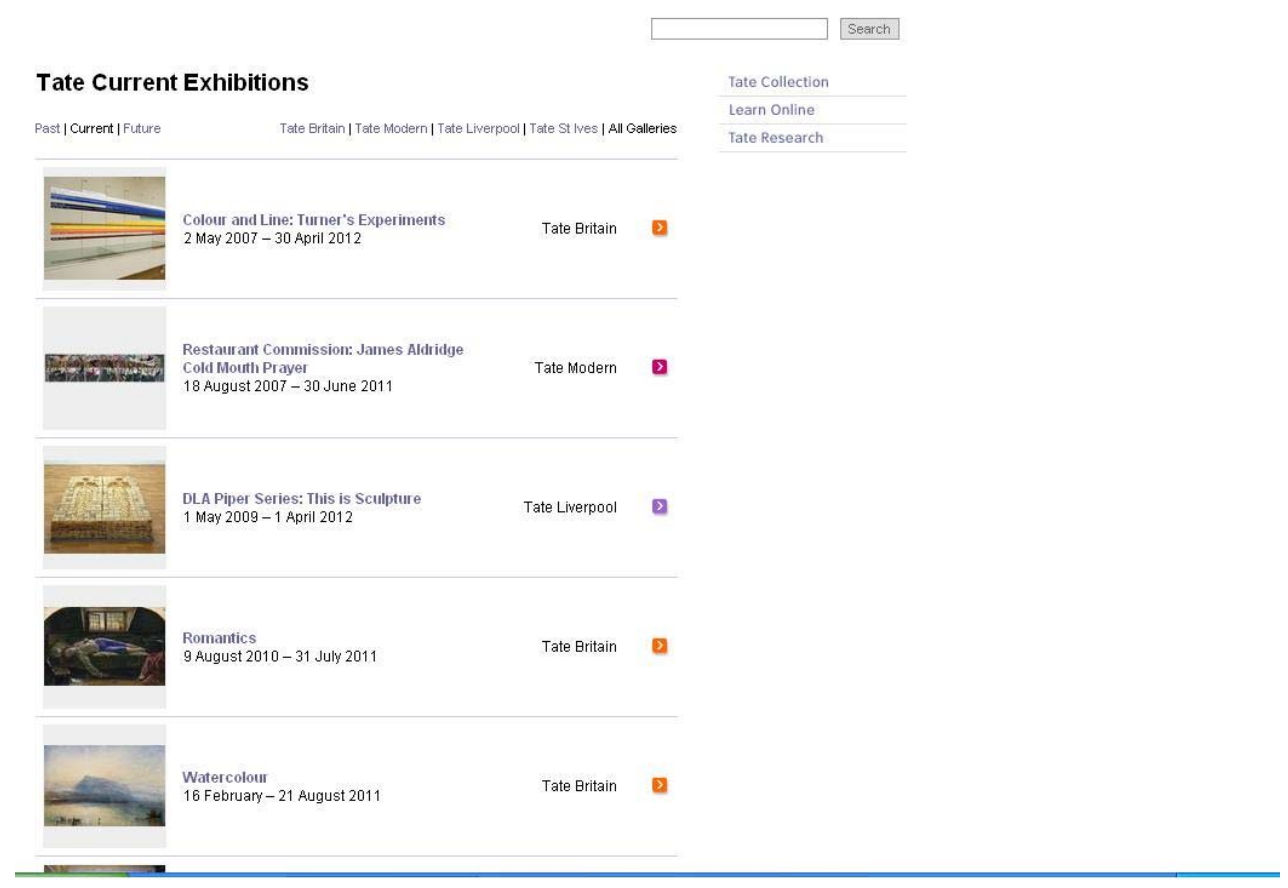

Imagem 9 - Página com agenda das exposições em cartaz nas quatro galerias

\section{Comunidades online, Blogs e Redes Sociais}

Cada página acessada dentro do site constitui-se como uma comunidade online onde o visitante explora seus conteúdos e registra suas impressões. As páginas aproximam-se da ideia de comunidade online, pois os conteúdos podem ser compartilhados, construídos e acessados pelos usuários de acordo com suas preferências. Os conteúdos como arquivos de vídeo e áudio são disponibilizados em blogs e nos espaços das redes sociais, em uma estratégia cada vez mais efetiva em envolver o público onde que quer ele esteja online, dentro ou fora do site da instituição; 


\section{Compartilhamento online}

Seja na elaboração de conteúdos desenvolvidos pelo museu ou na comunicação e relacionamento com o usuário, a ideia do site é democratizar o conhecimento e dar ao público a liberdade de compartilhar seus trabalhos com a TATE.

É então previsto que, os comentários gerados pelos usuários, até então reservados aos espaços dos fóruns de discussão e comunidades online ocupem e sejam difundidos, junto com a postura e a opinião da instituição, em toda a página principal.

O desenvolvimento do site ainda prevê ações de e-commerce (comércio eletrônico realizado via Internet) e espaço para a captação de doações e fundos para a instituição. Ao investigar o perfil do usuário cadastrado no portal, a TATE pode conhecer melhor seus visitantes potencializando a experiência que ele desenvolve durante a visita ao site. Isso permite também o desenvolvimento de ações de marketing mais segmentadas, personalizadas, e que explore o relacionamento a médio e longo prazo com o usuário.

Hoje, a maioria do conteúdo do site é distribuída gratuitamente. Porém, já foram identificadas oportunidades significativas em torno da geração de receita online. Assim, é possível que se tenha uma área com conteúdos especiais, como cursos, artigos, pesquisas, e que tenham sua reprodução e acesso cobrados.

O espaço para o comércio eletrônico é bem dimensionado, o visitante pode, por exemplo, ler um artigo sobre Francis Bacon, que está em exposição na TATE Modern, e, durante a leitura, ter acesso a caixas de textos promocionais, relacionando livros, pôsteres e outros materiais sobre o assunto em comum. Atualmente, a principal movimentação em torno do e-commerce é para a compra de bilhetes de entrada para as galerias e de produtos promocionais com a marca da instituição.

Outra oportunidade de negócios e investimento que deve em breve ser adotada pelo site é a criação de um programa de editoração digital. O programa TATE Publishing deve adotar ações de criação e manutenção de conteúdos de e-books ${ }^{31}$, aplicativos e recursos de imagens e impressões disponibilizados, em alta resolução, para aplicativos móveis, como celulares e iPads ${ }^{32}$, e a administração das áreas potenciais, identificadas dentro do site, para o desenvolvimento comercial da TATE e de seus produtos.

Cada vez mais, a Internet atualiza-se e os dispositivos e ferramentas de acesso e entrada na rede tornam mais acessíveis. A Internet móvel representa hoje uma importante parcela de usuários que estão conectados ao site da instituição, principalmente a partir da

\footnotetext{
${ }^{31}$ Livros digitais que podem ser lidos através de equipamentos eletrônicos como computadores e celulares.

32 Aparelho digital que tem como interface uma tela sensível ao toque, na qual os usuários podem acessar a Internet, visualizar fotos, vídeos, ler conteúdos em textos e acessar jogos e outros recursos de entretenimento.
} 
disseminação dos iPhones, espécie de celular desenvolvido pela Apple ${ }^{33}$, com recursos de armazenamento de conteúdos em som, vídeo e imagem, câmera digital, acesso à Internet via conexão wi-fi (rede local sem fio), além de mensagens de texto e aplicativos de jogos e entretenimento.

Há, então, uma preocupação cada vez maior da TATE em estar presente nos momentos de lazer e entretenimentos desses usuários móveis. Desde ajustes e seções específicas do site para ser acessadas em telas pequenas e dispositivos móveis, o aprimoramento de ferramentas para a construção de comunidades online, até a possibilidade de comunicação e interação com o site da instituição através de recursos com base no sistema $\mathrm{SMS}^{34}$.

Para administrar todos esses recursos já citados e a criação de outros dispositivos de comunicação e relacionamento com o público que já foram diagnosticados como fundamentais para estreitar os laços da instituição e se fazer presente na rotina e na construção ligada à ideia do que é reconhecido como autoridade no que diz respeito aos conceitos e conteúdos ligados às Artes, é fundamental que se tenha um bom plano de gerenciamento e expansão dos conteúdos.

Uma das metas a ser alcançada para a TATE até 2015 é a utilização de novos sistemas para realizar a inserção rápida e atualizada dos conteúdos disponibilizados no site, além da distribuição e divisão em torno da organização destes entre os curadores e editores que deverão supervisionar este trabalho. Para alcançar esses objetivos é necessária uma reformulação na arquitetura do site e em sua infraestrutura. Com o apoio e parceria da BT, o site deve contar com sistemas de gestão de conteúdos e funcionalidades integradas, identificadas em cinco grandes áreas:

- Sistemas de gerenciamento de conteúdos;

- Serviços de coleta de informações sobre o museu;

- Sistema de vendas e e-commerce;

- Sistema de buscas;

- Login e espaço do usuário;

- Sistema de gestão de relacionamento com o usuário

\footnotetext{
33 A Apple Inc. é uma empresa norte-americana que atua no ramo de aparelhos eletrônicos e informática, responsável pela fabricação do iPad e iPhone, entre outros produtos.

Disponível em http://www.apple.com/, acesso em abril de 2011.

${ }^{34}$ Abreviação de Short Message Service, é um de serviço de comunicação de telefone, web ou sistemas de comunicações móveis que permitem a troca de mensagens curtas de texto.
} 
Além disso, há a necessidade de investigar novas formas de medir a participação e a interação do usuário com o portal, seja através da participação nas redes sociais ou comunidades online, ou na utilização de produtos e serviços disponíveis.

As ações e o potencial de alcance da plataforma virtual da instituição estão cada vez mais centradas no internauta e na forma de atraí-lo para o site, não apenas como um público potencial para uma possível visita a uma das quatro galerias da TATE, mas como cidadãos de uma sociedade cada vez mais informatizada e virtualizada, uma sociedade que se reconhece nos limites, recursos, relações e relacionamentos da Cibercultura.

A TATE foi um dos primeiros museus a publicar imagens digitalizadas de sua coleção online e criar, assim, uma exposição virtual, um contexto para as obras.

Desde o início, procurou desenvolver uma nova compreensão dos códigos de ética exigidos para navegar no espaço virtual com responsabilidade, diferenciando-os das ações museológicas atuais e quais as suas responsabilidades ao lançarem-se sobre um novo tipo de espaço, ainda sem leis e funções bem definidas, com todo o tipo de público, levantando questões em torno da liberdade de expressão e expectativas dos usuários.

Está, entre uma de suas missões, fomentar a pesquisa qualitativa sobre os mais diversos usos dos materiais do museu produzidos dentro do ambiente virtual, uma área que poderia proporcionar novos entendimentos do valor social e educativo dos conteúdos culturais em rede.

\subsection{Parceria TATE e BT - valores e conteúdos}

A parceria entre a TATE e a BT começou em 2001. Até esse ano, a média de acessos ao site da instituição era de cerca de 100.00 usuários por mês.

Desde o início, a BT oferece suporte e serviços de design criativo e apoio técnico, além se constituir-se como patrocinador exclusivo da TATE, que contribuiu para o desenvolvimento de ferramentas e novas tecnologias, iniciativas inovadoras para projetos de interfaces e recursos interativos disponibilizados no site, aumentando seu alcance e tornando o site da TATE um dos sites de artes mais reconhecidos e visitados do Reino Unido.

Além do desenvolvimento de estratégias para tornar o portal TATE Online reconhecido pelos cidadãos britânicos e visitado pelos usuários online de todo o mundo, a parceria entre as duas instituições gera ainda uma série de recursos e serviços que só podem ser oferecidos graças à união entre o material TATE e a iniciativa BT.

Entre eles está a digitalização de uma série de arquivos em filmes e áudio do acervo da TATE. São filmes de artistas, entrevistas com curadores, críticos e todo tipo de material e 
registro da instituição desde o início dos anos 1960 até os dias atuais. Esse material fica disponível para ser acessado através do recurso TATE Media Player, desenvolvido pela BT. Com um menu de acesso rápido dentro do portal, o TATE Channel, como é chamado, dispõe ainda de ferramentas de pesquisa e editor de fotos, além de links diretos para os espaços da TATE no Youtube e iTunes ${ }^{35}$; com capacidade de armazenamento praticamente ilimitadas, os podcasts ${ }^{36}$ são constantemente atualizados e avaliados pelos usuários online.

Em 2006, mais de 70 mil arquivos em audiovisual envolvendo artistas e pensadores da cultura haviam sido digitalizados.

Desde que a BT tornou-se patrocinadora exclusiva da TATE Online, o número de visitantes aumentou para cerca de dois milhões de usuários por ano e um dos recursos mais acessados são os arquivos em vídeo disponíveis no TATE Channel.

Em junho 2002, a TATE realizou a primeira pesquisa online com os usuários do site a fim de traçar um perfil desse visitante e sua avaliação sobre o conteúdo disponível. Verificou-se que ${ }^{37}$ :

- $30 \%$ dos entrevistados acessavam o site pelo menos uma vez por mês;

- $45 \%$ visitavam primeira vez;

- $66 \%$ dos entrevistados eram do Reino Unido;

- $15 \%$ dos entrevistados nunca visitaram uma das Galerias TATE;

- $85 \%$ classificaram a qualidade de conteúdo online como excelente;

- $48 \%$ visitaram o site para obter informações sobre a programação das galerias;

- $39 \%$ visitaram para ver ou saber mais sobre as obras de arte na coleção.

Observou-se, ainda, que o tempo médio gasto na TATE Online por visita é de mais de sete minutos, o que é considerado acima da média gasta pelos usuários ao visitar sites em geral.

No início, o objetivo maior da parceria era fornecer um meio virtual de navegar pela coleção da TATE, além de preparar o visitante para a experiência da visita ao museu ou fornecer àqueles que não poderiam estar nas galerias a oportunidade de se envolver com as obras da coleção.

O desenvolvimento do site, dos acessos, e as próprias mudanças alcançadas pela Internet trouxeram a TATE Online para frente das ações, não mais percebida como veículo de promoção ou divulgação das atividades do museu, mas como plataforma de interação,

\footnotetext{
35 Serviços de compartilhamento de áudio e vídeo.

${ }^{36}$ Método de construção de arquivos multimídia em formato de áudio ou vídeo em que o download é feito através de um arquivo em formato RSS disponível na Internet.

${ }^{37}$ Disponível em http://www.tate.org.uk/information/online/, acesso em maio de 2011.
} 
colaboração, identificação e construção de conhecimento com o usuário; a TATE ganha assim uma quinta galeria que tem como foco principal o relacionamento com o público.

Um dos fatores de sucesso da parceria é o reconhecimento do público local com as marcas TATE e BT. Ambas tem uma forte aproximação na vida do cidadão britânico, são reconhecidas como produtos de identificação nacional e sua união técnica, comercial e institucional agregam valores na busca por novos públicos e acessos para a informação sobre as Artes.

O sucesso da parceria é também atestado pelo número de prêmios que o site conquistou. Desde 2001, foram mais de 20 prêmios da indústria ligada às Artes, Entretenimento e Comunicação concedidos à TATE pelas ações pioneiras na utilização da tecnologia para aumentar o acesso às informações sobre as Artes para novos públicos. Entre os principais estão:

2010

\section{Webby Awards}

Melhor Website de Arte

2009

\section{Webby Awards}

Melhor Website voltado ao público jovem, pelo programa TATE Kids

2007

\section{Webby Awards}

Categoria Arte Net

2004

\section{Museus e a Web}

Melhor Site de Pesquisa

2002

\section{Bafta Interactive}

Acessibilidade, pelo desenvolvimento de conteúdo disponibilizado em iMap, voltado ao público com deficiência visual

\section{Bafta Interactive}

Inovação Tecnológica , pela ferramenta TATE Modern Tour Multimídia 
Em agosto de 2001, foi realizada uma pesquisa de mercado pela agência MORI ${ }^{38}$ para identificar o perfil e o nível de interação dos usuários com o site. Ao todo 1.123 visitantes completaram o preenchimento do questionário que estava disponível apenas em inglês. Foram observados os seguintes dados ${ }^{39}$ :

- $59 \%$ dos entrevistados viviam no Reino Unido, 21\% na América do Norte, $14 \%$ da Europa, 6\% nas demais regiões;

- $42 \%$ dos usuários haviam localizado o site através de um software de busca (Yahoo, AltaVista e Google foram os mais citados);

- A maioria dos internautas não eram visitantes frequentes da instituição: 38\% não haviam visitado nenhuma das quatro galerias TATE durante os últimos dois anos, e $24 \%$ visitaram apenas uma vez;

- $\quad 48 \%$ dos internautas acessavam o site pela primeira vez;

- A maioria dos usuários utilizou o serviço de compras online: $60 \%$ compraram livros, 43\% CDs, 35\% comprou algum item para presentear, 30\% adquiriu bilhetes para algumas das exposições em cartaz, e 8\% fizeram doação à instituição através do site;

- Os motivos mais citados para visitar o site foram: visualizar ou encontrar informações sobre obras de arte (50\%), informações sobre as exposições permanentes (36\%), exposições temporárias (31\%), endereços e horários de funcionamento das galerias (27\%);

- $80 \%$ das pessoas entrevistas avaliaram como boa ou muito boa a quantidade e a qualidade das informações disponíveis, $76 \%$ deram a mesma classificação para o design do site e $67 \%$ para a velocidade de download;

- $85 \%$ disseram ter aproveitado a experiência no site e $80 \%$ planejavam conhecer o espaço do museu a partir da visita virtual.

Os dados observados na pesquisa demonstram que o próprio público/usuário da rede esperava encontrar no site da instituição um suporte para a visita presencial ao museu, ou informações sobre Artes e as obras na coleção da TATE.

É o desenvolvimento do Ciberespaço, e sua ocupação cada vez maior pelos usuários que vão, ao mesmo tempo, moldando e estruturando suas informações e o grau de interação possível que vai ser percebido e avaliado pela instituição e por seu potencial de reconhecimento e parceria com o visitante, mudando a configuração do site que deixa de

\footnotetext{
38 Ipsos MORI é uma empresa britânica de pesquisa publicitária com foco em Marketing, Gestão de Relacionamentos e Tecnologia. Disponível em http://www.ipsos-mori.com/aboutus.aspx, acesso em maio de 2011.

${ }^{39}$ Disponível em http://www.tate.org.uk/about/pressoffice/pressreleases/290801.htm, acesso em maio de 2011.
} 
ser apenas uma ferramenta para a divulgação das obras e ações do museu e passa a caracterizar-se como a própria experiência estética, que pode começar e terminar na visita ao portal, trazendo informações sobre Arte, sobre a coleção, a visão e o posicionamento da TATE, não como um discurso sobre Arte fechado e hermético, mas sim como atividade crítica, lúdica e experimental.

\subsection{0 site do MAC - USP}

O site do MAC-USP existe desde 1995 e é, provavelmente, um dos primeiros sites de museus brasileiro. Ele foi idealizado pelos próprios funcionários do recém criado Núcleo de Informática e por pesquisadores do museu, especialmente pela Profa. Daisy Peccinini ${ }^{40}$.

O projeto inicial para a criação do site foi elaborado durante a primeira gestão (1994 - 1998) da Profa. Lisbeth Rebollo ${ }^{41}$. A ideia era criar e sistematizar o acesso aos dados e informações sobre as obras do acervo, de modo que elas pudessem ser armazenadas e localizadas de forma mais fácil pela equipe técnica, uma espécie de Intranet.

Esse sistema já disponibilizava, também para o público externo, informações sobre as obras, exposições e o funcionamento do museu como um todo. E logo em 1995, já surgiu a ideia de oferecer uma exposição dentro do site.

De junho a agosto daquele ano, estava em cartaz na sede do MAC, na Cidade Universitária, a exposição Modernismo Paris Anos 20 - Vivência e Convivências, que apresentava a obras de três grandes artistas, Victor Brecheret, Antonio Gomide e Vicente do Rego Monteiro, que conviveram em Paris nos anos 1920.

Essa foi também a primeira exposição a ganhar as páginas do MAC. Inicialmente, a ideia foi disponibilizar no site as obras digitalizadas que faziam parte da exposição na sede do museu, e que poderiam ser vistas pelos visitantes por intermédio do site.

Em 1998, com a mudança na diretoria do museu, assume, como vice-diretor, o Prof. Martin Grossmann ${ }^{42}$. O Prof. Martin já havia sido um dos responsáveis pela implantação do sistema USP Online, o qual é hoje responsável pelo gerenciamento do Portal da USP

\footnotetext{
${ }^{40}$ Daisy Peccinini é formada em História pela Faculdade de Filosofia, Ciências e Letras da USP. Realizou PósDoutorado no Collège de France e Livre Docência em Estética e História da Arte pela Escola de Comunicações de Artes da USP. Atuou como professora do Programa de Pós-Graduação Interunidades em Estética e História da Arte MAC/USP e desenvolveu para o site do MAC o projeto de Pesquisa Arte do século XXIXXI - visitando o MAC na Web.

${ }^{41}$ Lisbeth Rebollo é professora titular da Universidade de São Paulo. Formada em Ciências Sociais pela Universidade de São Paulo, com mestrado e doutorado em Sociologia pela mesma universidade, tem experiência na área de Sociologia, com ênfase em Outras Sociologias Específicas. Foi Diretora do Museu de Arte Contemporânea da Universidade de São Paulo de 1994 a 1998 e de 2006 a 2010. Atualmente é Presidente da Associação Brasileira de Críticos de Arte - ABCA e Vice Presidente da Associação Internacional de Críticos de Arte - AICA.

${ }^{42}$ Martin Grossmann é professor titular da Universidade de São Paulo; foi criador e coordenador do USP Online, portal de informações da USP na Web, de 1995 a 1998.
} 
(www.usp.br), um dos maiores portais acadêmicos do Brasil. A partir dessa experiência, sua ideia era criar um serviço dentro do site, que disponibilizasse ao visitante informações sobre todo o conteúdo e atividades realizadas pelo museu.

Esse processo, que vai de 1998 a 2002, gera as bases do que conhecemos hoje como o site MAC Virtual.

Um das intenções era manter, dentro do site, a mesma linguagem da exposição virtual e da exposição em cartaz na sede do museu. Dessa fora, a cada troca de exposição e conceitos de curadoria, haveria uma linguagem diferente dentro do site.

Oficializada em fevereiro de 2002, a parceria entre o MAC-USP e o Grupo Santander Banespa previa o patrocínio total de $\mathrm{R} \$ 1$ milhão a serem usados no prazo de cinco anos. $\mathrm{O}$ foco principal da parceria era a implantação do MAC Virtual, projeto desenvolvido para o site do museu, que tem como objetivo principal a inserção das imagens digitalizadas das obras do acervo do museu no site. O contrato de exclusividade como patrocinador do site previa ainda a divulgação no portal Universia (www.universia.com.br/), também apoiado pelo Grupo. A USP, com sua divisão USP Online, também se responsabilizaria pela divulgação do projeto, que contaria ainda com a colaboração da empresa FullTecno, que em parceria com a equipe do museu, foi responsável por sua construção e desenvolvimento, além de registros fotográficos de Rômulo Fialdini e Sérgio Guerini.

Esse novo projeto pretendia refazer a interface, criar um novo design e uma identidade visual, utilizando também novas ferramentas e recursos tecnológicos para a adição de conteúdos relacionados à aprendizagem e interação do usuário, mas sempre com foco na digitalização do acervo e no alcance da coleção a um público maior. Essa preocupação dá-se pela dificuldade em exibir a maior parte do acervo. O museu possui uma coleção especializada em arte brasileira e internacional do século XX, com cerca de 10 mil obras, das quais apenas $2 \%$ são expostas, pelas limitações e falta de espaço nas próprias instalações do museu.

Outro fator é que, por se tratar de um Museu Universitário, uma instituição que funciona como fonte de geração de pesquisa e de conhecimentos para a sociedade, tem como eixo central as questões ligadas à pesquisa, mediação, atualização e conhecimento do seu acervo e como essas ações podem ser levadas ao público. A digitalização das obras e a facilitação de seu acesso na rede cumpriria, em parte, esse papel.

\subsection{O Projeto MAC Virtual}

O MAC Virtual, desenvolvido e implantado durante a gestão da Profa. Elza Ajzenberg $^{43}$, é uma plataforma que visa estruturar, divulgar e projetar as obras do Museu de

${ }^{43}$ Elza Maria Ajzenberg é professora titular da Universidade de São Paulo, coordenadora do Centro Mario Schenberg de Documentação da Pesquisa em Artes da Escola de Comunicações e Artes da Universidade de 
Arte Contemporânea da Universidade de São Paulo - MAC USP, com o objetivo de integrar a arte à tecnologia digital.

O MAC-USP foi criado em 1963 quando a Universidade de São Paulo recebeu do então presidente do Museu de Arte Moderna de São Paulo, Francisco Matarazzo Sobrinho, as obras que constituíam seu acervo. Somaram-se, a essa coleção, as doações de coleções particulares feitas por Francisco Matarazzo e sua esposa, Yolanda Penteado, e a incorporação de obras internacionais cedidas pela Fundação Nelson Rockfeller e Prêmios das Bienais Internacionais de São Paulo. Hoje, o Museu de Arte Contemporânea possui uma coleção nacional e internacional especializada em obras do século $\mathrm{XX}$, ampliando seu acervo, com cerca de 10 mil obras, à atualidade ${ }^{44}$.

Por constituir-se como uma instituição ligada ao ensino, à pesquisa e à extensão universitária, com sede no campus da Universidade de São Paulo, conta com uma equipe multidisciplinar de funcionários, docentes e pesquisadores.

Para a elaboração do projeto MAC Virtual e adequação às necessidades e perspectivas do Museu contou-se, além dessa equipe, com a participação de alguns pesquisadores e técnicos da POLI, Escola Politécnica da Universidade de São Paulo, que daria suporte tecnológico e soluções para alguns problemas já identificados como o armazenamento dos arquivos de imagens e a criação de recursos de interação com o usuário.

O portal MAC Virtual previa o uso de recursos de animação, ferramentas multimidiáticas, imagens tridimensionais e visitas a exposições virtuais, dividindo o site em três grandes áreas de funcionamento, de acordo com os serviços e funções desenvolvidas dentro do museu.

$\mathrm{Na}$ fase inicial deu-se a digitalização de uma parte das obras do acervo, associada à produção de textos específicos. Era como se cada obra inserida no site tivesse uma espécie de ficha que continha informações com um texto crítico sobre o artista, técnica, período e ficha técnica.

Além do acervo, o projeto contava com a ideia de promover uma visita virtual ao museu, em um ambiente que recriava uma sala expositiva, e a divulgação de informações de exposições, cursos, projetos, vídeos institucionais e um ambiente dedicado ao serviço educativo, com atividades direcionadas ao público infantil.

Com todas essas ações a perspectiva era utilizar a Internet como plataforma de divulgação das ações do museu para a captação de um público maior, além de caracterizar-

São Paulo (desde 1990) e foi Diretora do Museu de Arte Contemporânea da Universidade de São Paulo de 2002 a 2006. Disponível em disponível em http://www4.usp.br/index.php/institucional/5047, acesso em janeiro de 2011.

44 O MAC-USP vai receber um novo prédio para guardar e exibir sua coleção. Desenvolvido pelo arquiteto Oscar Niemeyer em 1951, o edifício abrigava o antigo Palácio da Agricultura e, atualmente, abriga o DETRAN -SP. 
se como um espaço de interesse para estudantes, professores, pesquisadores e público em geral.

Logo no início, a principal necessidade encontrada foi a criação de um banco de dados especialmente voltado para atender a pesquisa em arte, capaz de estruturar, divulgar e projetar as informações e atividades oferecidas pelos setores do MAC USP, em três diferentes idiomas: português, inglês e espanhol.

A organização do MAC Virtual está dividida em três eixos temáticos:

- Museu Universitário: área responsável pela divulgação de informações gerais sobre o Museu, como organograma, exposições, cursos, projetos, acervo, catálogo, eventos, documentário, vídeo institucional, visita virtual, atividades do MAC USP, parcerias, bibliotecas e notícias;

- Museu Experimental: relacionado a projetos, intercâmbios, curadoria virtual, criações, acompanhamento de resgate de obras e outras iniciativas;

- Museu Lúdico: espaço que concentra os projetos educacionais, jogos e atividades interativas, como a Máquina de Barulhar, Quebra Cabeça Dura, Desenho Livre, Arte + 3D, Monte e Crie e a A Cor da Obra, com o objetivo de incentivar a interatividade do museu com escolas e estudantes.

Ao acessar o portal MAC Virtual, encontramos uma interface com sete menus móveis localizados à esquerda da tela que vão nos guiar para dentro do site e distribuir as informações dentro dos três eixos de organização, quais sejam: Institucional, Acervo, Exposições, Cursos, Eventos, Projetos, Biblioteca. 


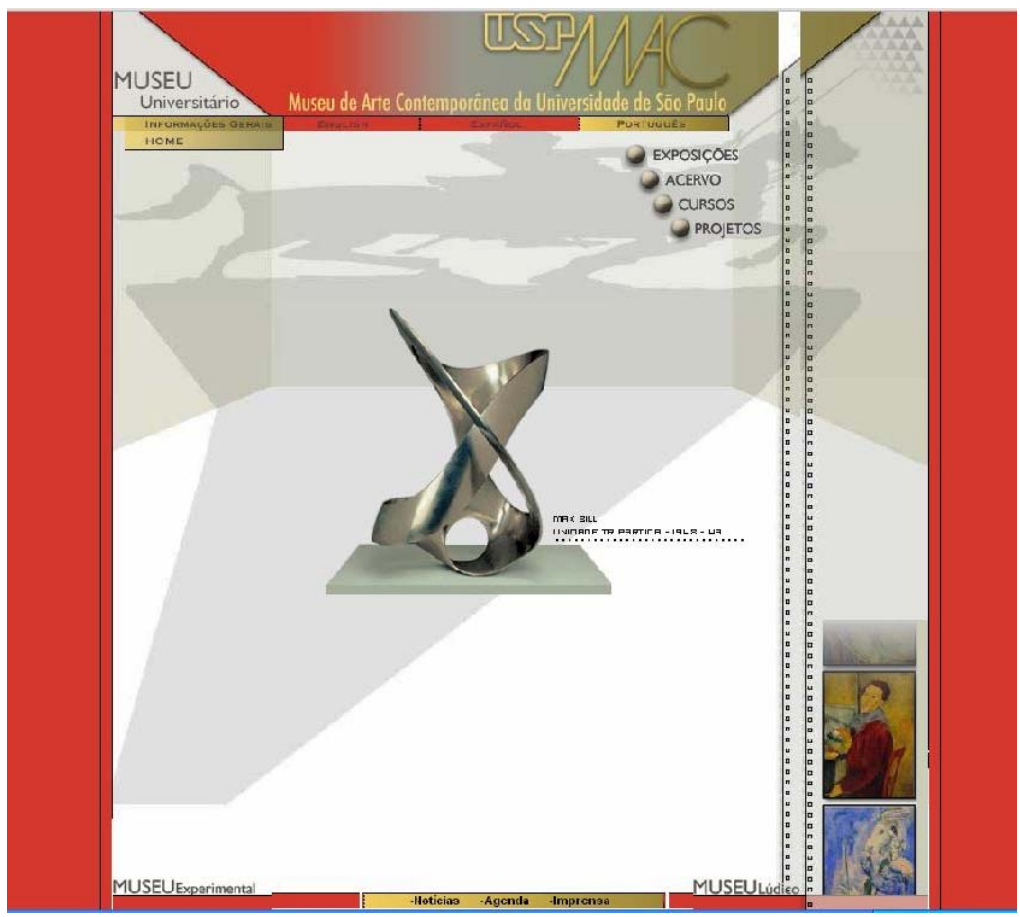

Imagem 10 - Detalhe da página inicial do MAC Virtual

O menu Institucional oferece uma página com um breve histórico de criação do museu, e informação sobre suas duas sedes localizadas na Cidade Universitária e uma no Pavilhão Ciccillo Matarazzo, no Parque do Ibirapuera.

Em Acervo, encontramos uma página para pesquisa das obras digitalizadas da coleção. A busca pode se dar através de três classes: Obras, com possibilidade de pesquisa por autor, título, descrição, movimento, tema, tendência, técnica, período, coleção e gabinete de papel; Catálogo Virtual, onde aparecem as imagens das obras apresentadas em ordem alfabética de acordo com seu autor, e Glossário, onde pode-se encontrar informações sobre movimentos e correntes artísticas do final do século XIX e século XX.

Sempre que a opção pela pesquisa for por Obras, os resultados encontrados são disponibilizados em uma esteira na parte superior da tela, fornecendo um resultado por figuras. Assim, basta clicar na figura desejada e as informações podem ser visualizadas.

A criação do banco de dados é centrada na classe Obras, cada qual com seu nome, ano de produção, materiais utilizados, entre outras informações. Cada obra possui um conjunto de três imagens, que são visualizadas de acordo com o sistema de conexão do usuário, alta ou baixa velocidades, além de informações sobre autor, movimento e tendência. 

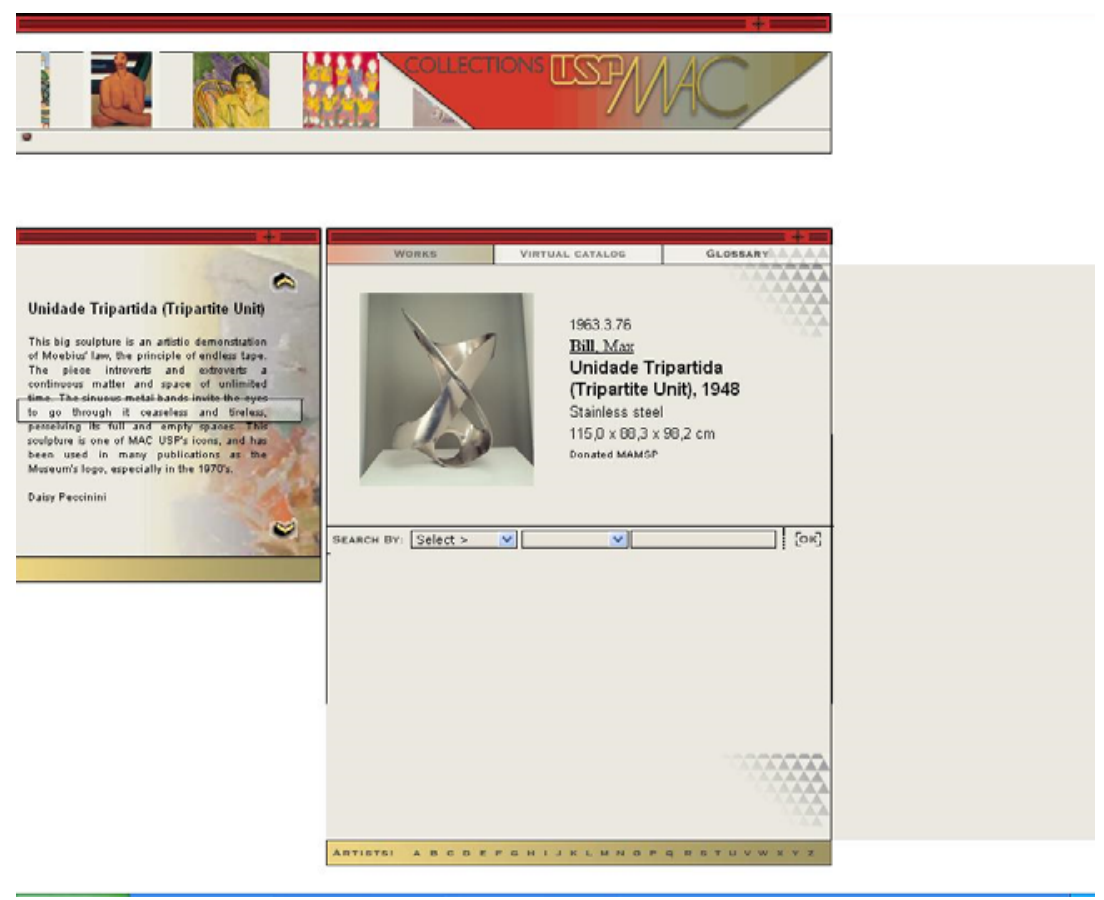

Imagem 11 - Detalhe da página com acesso ao banco de dados do Acervo

$\mathrm{Na}$ sessão Exposições encontra-se o serviço das exposições em cartaz nas duas sedes do MAC, além do acesso aos arquivos das exposições anteriores, a partir de 1997, com informações sobre o período de realização e um texto sobre o assunto.

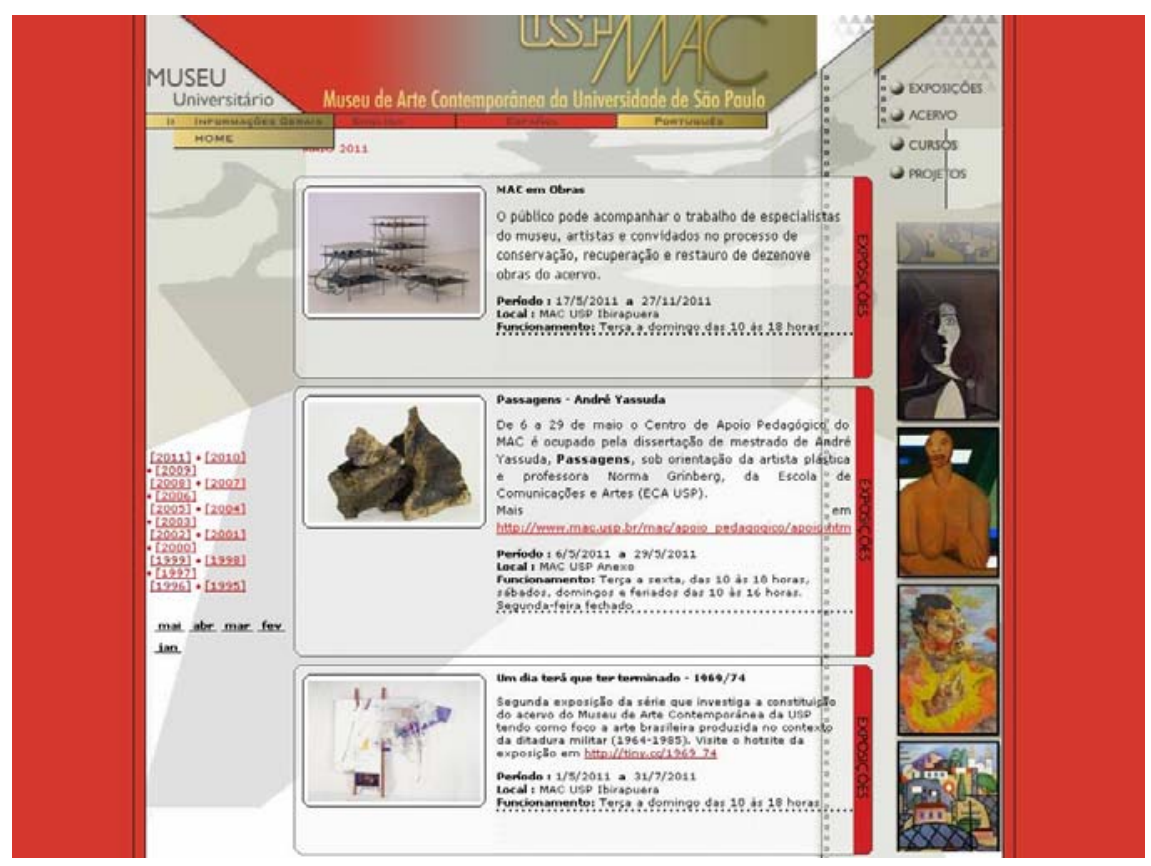

Imagem 12 - Detalhe da página com informações sobre as Exposições 
As páginas direcionadas a Cursos e Eventos trazem informações sobre as atividades desenvolvidas dentro do museu para a comunidade, como palestras, visitas monitoradas, cursos, encontros com artistas, atividades para jovens, crianças e professores.

O campo Projetos lista projetos e parcerias nacionais e internacionais desenvolvidos pelo MAC além de outras iniciativas. Entre eles, podemos destacar Arte do Século XXIXXI Visitando o MAC na Web, projeto de pesquisa criado e coordenado pela Profa. Daisy Peccinini, que trás um panorama da História da Arte dos séculos XX e XXI a partir das obras e artistas presentes na coleção do MAC.

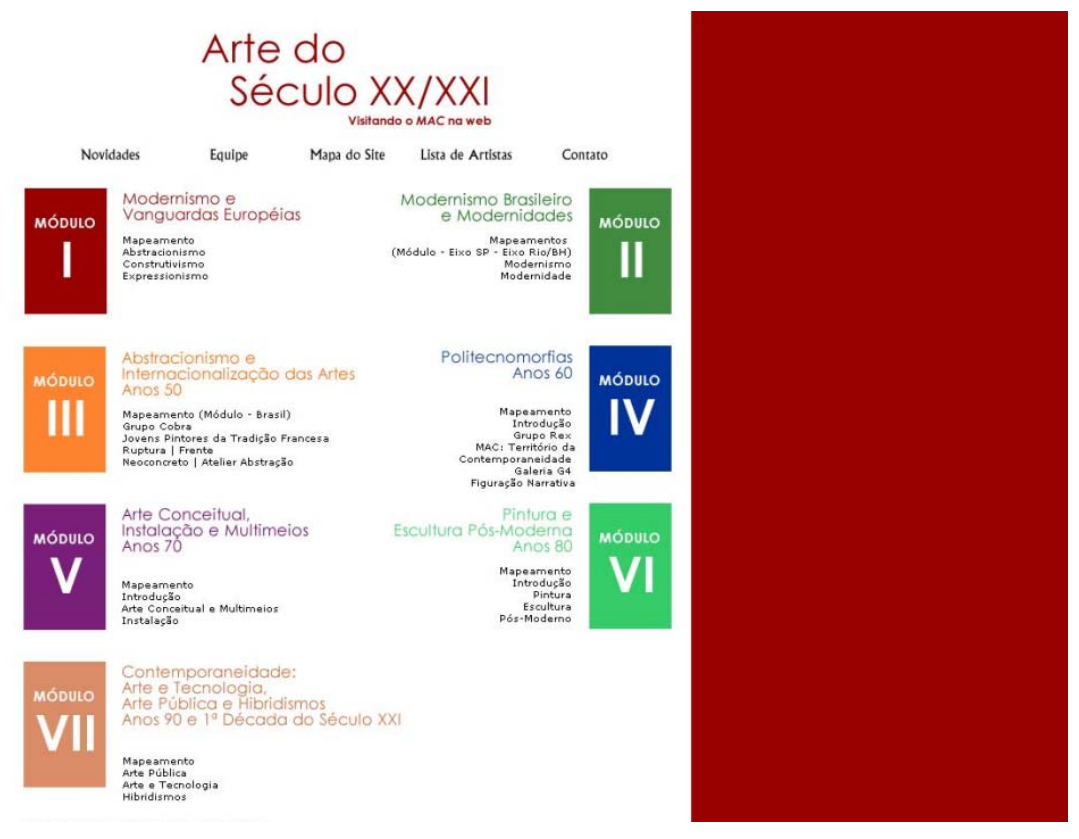

Imagem 13 - Detalhe da página Arte do Século XX / XXI - Visitando o MAC na Web

A página da Biblioteca oferece informações sobre seu funcionamento, além do acesso à base de dados ao sistema integrado das bibliotecas da USP. 


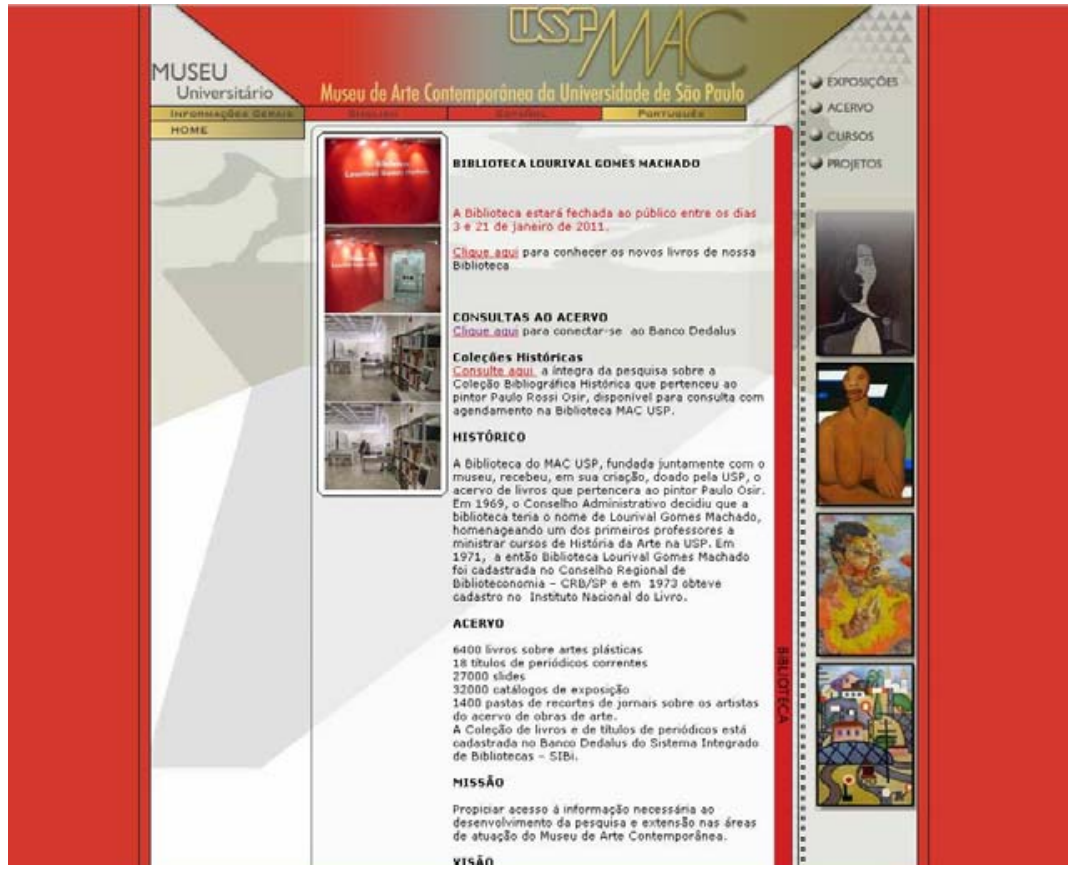

Imagem 14 - Detalhe da página com informações sobre a Biblioteca

No que diz respeito à estrutura do site, a página inicial, que dá acesso ao portal MAC Virtual, é a área que corresponde ao Museu Universitário. Inicialmente, continha uma breve introdução do que era o projeto e todas as estruturas disponíveis no site, menus de navegação e acesso identificado às duas outras regiões, Museus Lúdico e Experimental.

Todas as páginas do site possuíam o mesmo formato, onde o conteúdo aparecia em destaque, ocupando a área central da página. Os demais conteúdos encontram-se no banco de dados, nas laterais, em que havia duas opções de menu.

Um menu retrátil, do lado esquerdo, que se movimenta conforme o toque do mouse, dá acesso às seguintes seções:

- MAC USP: o que é o museu, suas sedes e localizações;

- Organograma: profissionais que compõem o museu;

- Mapa do site: estrutura organizacional do site;

- Visita Virtual: passeio $360^{\circ}$ pelo museu;

- Catálogo Virtual: obras digitalizadas do acervo do museu;

- Vídeo institucional: vídeo com informações sobre o museu;

- Eventos: divulgação dos eventos que acontecem no museu;

- Atividades: divulgação das atividades promovidas pelo museu;

- Biblioteca: acesso às obras catalogadas pela biblioteca do MAC;

- Sobre o MAC Virtual: informações sobre o projeto e parcerias;

- Fale Conosco: canal de comunicação do usuário com o museu; 
- Busca: sistema de busca e pesquisa dentro site.

E um menu estático, à direita, com as seguintes opções:

- Exposições: informações sobre as exposições em cartaz e as já realizadas pelo museu;

- Acervo: consulta ao acervo virtual do museu;

- Cursos: informações sobre cursos patrocinados pelo museu;

- Projetos: projetos, intercâmbios e atividades realizadas pelo museu.

$\mathrm{Na}$ parte superior da tela, havia um cabeçalho que informava em que área do site o visitante se encontrava e que tinha o logo do MAC USP.

Na parte inferior, havia links de acesso para as seções: Notícias, Agenda, Imprensa, que permitiam que o usuário consultasse de forma rápida as três últimas ocorrências registradas em cada uma das áreas, além de todas as informações já cadastradas, separadas por mês e ano.

A desvantagem é que toda vez que uma dessas seções é acessada abre-se uma nova janela, ou seja, as informações não estão interligadas, elas funcionam independentemente, abrindo sempre uma nova janela de acesso ao usuário, o que dificulta a navegação e o reconhecimento do site e do assunto em questão.

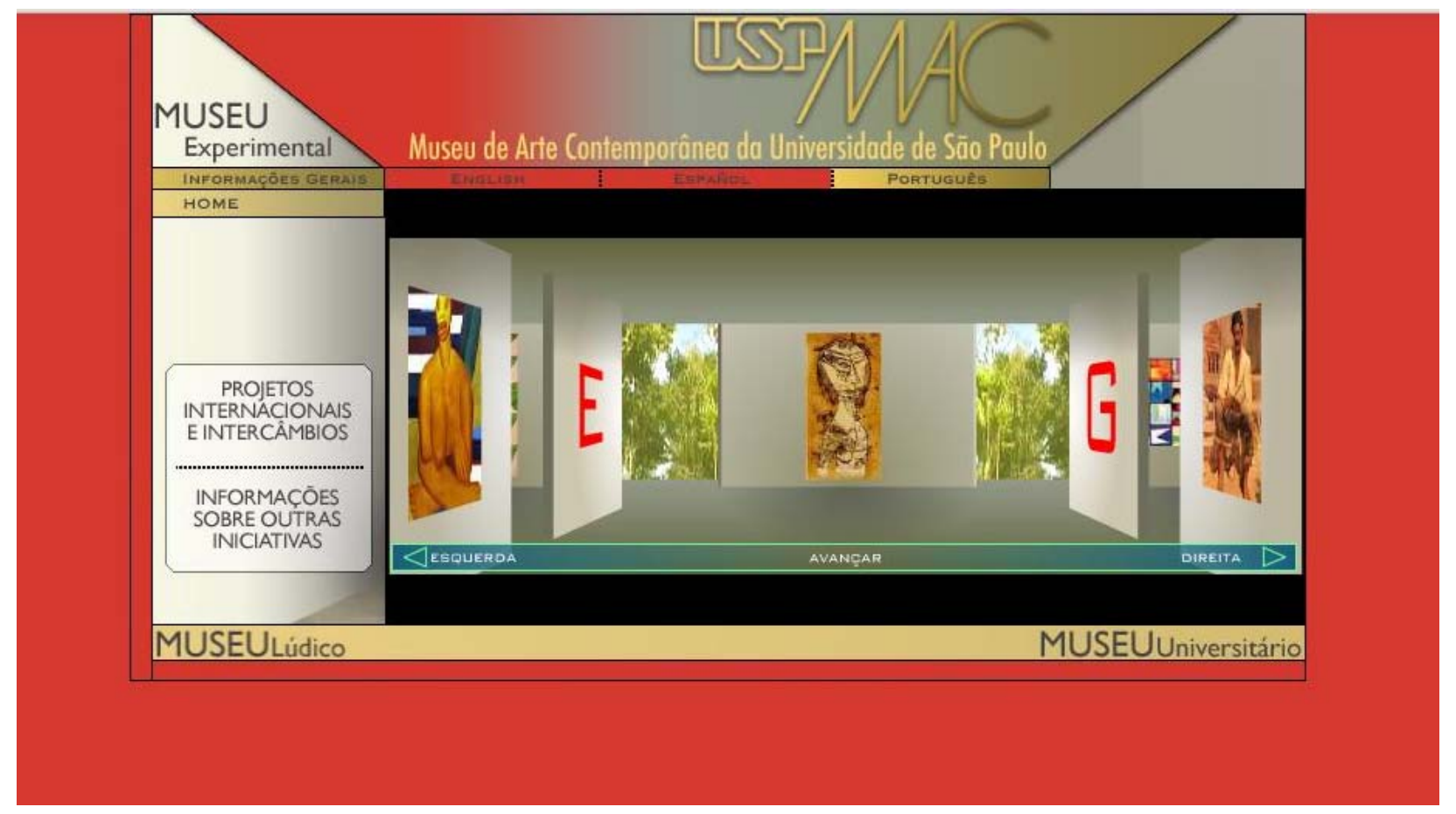

Imagem 15 - Detalhe da página Museu Experimental 
Já as áreas reservadas aos Museus Experimental e Lúdico tinham a intenção de realizar projetos experimentais desenvolvidos dentro do site.

A Visita Virtual, recurso disponível dentro da seção Museu Experimental, mostra um mapa do museu onde o visitante pode se movimentar, aproximar-se de algumas obras e ter a sensação de "visitar" as instalações físicas do MAC USP. Essa visitação, ou seja, as obras mostradas independem da exposição atual em cartaz no museu, são fixas e mostram uma parte do acervo que normalmente não estão em exposição permanente na sede do museu.

O Museu Lúdico é uma seção voltada ao público infantil com alguns recursos de interação, como ferramentas para mudar a cor de determinada obra, montar novas imagens a partir de recortes de outras obras do acervo, ferramentas de desenho, som e um jogo de quebra-cabeça, todas com um nível de interação bem simples e limitado.

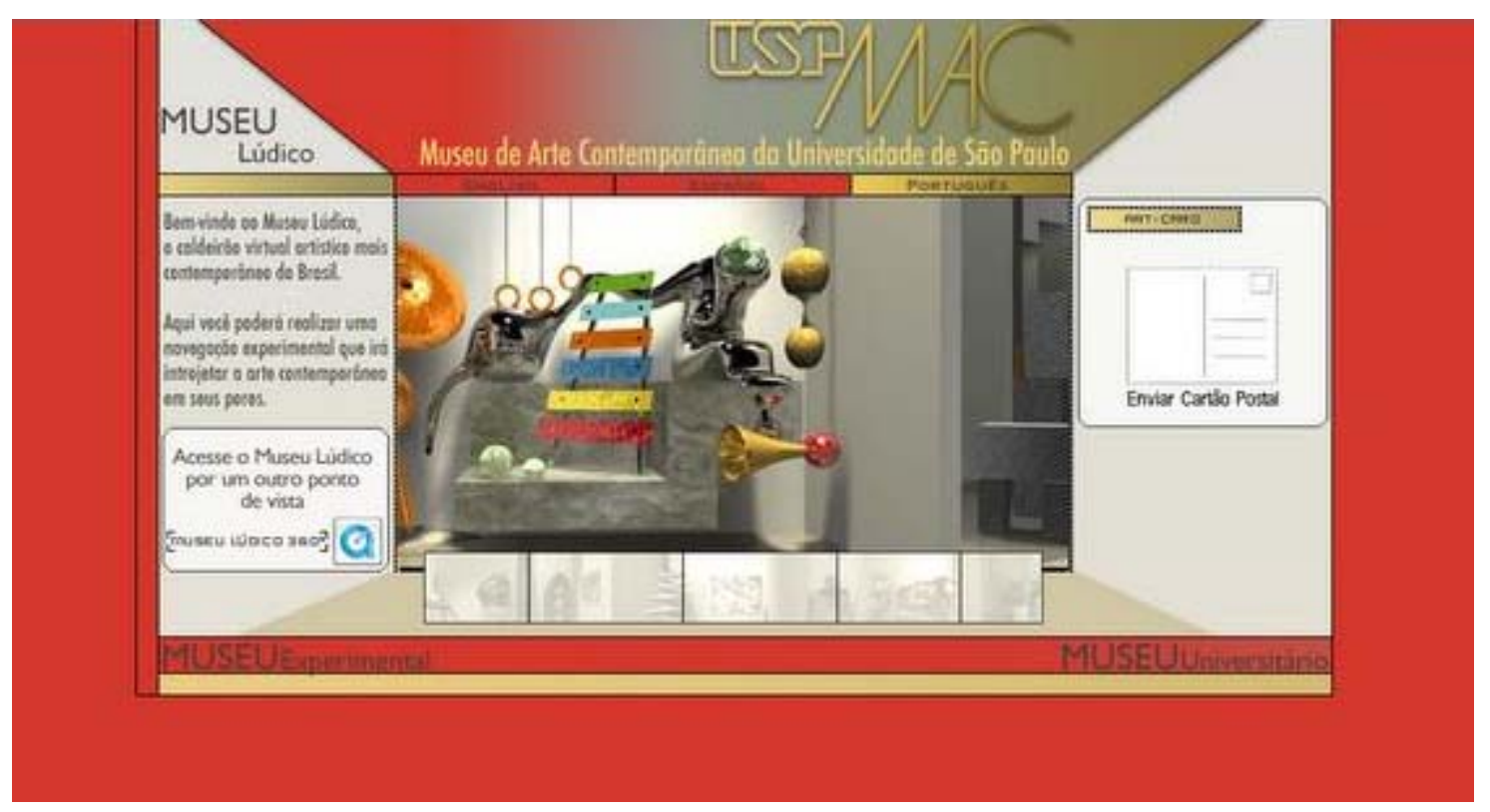

Imagem 16 - Detalhe da página Museu Lúdico

O gerenciamento do site MAC Virtual é feito por uma página simplificada, o cabeçalho é padronizado em todas as páginas e há um menu lateral dividindo as áreas em Museu Universitário, Lúdico e Experimental. O sistema foi desenhado de forma a não permitir que registros sejam apagados, evitando uma eventual perda de informações.

Dentro do Projeto MAC Virtual havia a intenção de criar uma plataforma de Curadoria Virtual. Esse recurso teria como objetivo desenvolver um sistema no qual os usuários pudessem construir exposições virtuais que poderiam ser visitadas por outros usuários dentro de um ambiente gráfico 3D. Essa plataforma faria o cadastro e validação dos usuários, geraria visualizações, e faria interface com o banco de dados do museu. A ideia era que o visitante, após se cadastrar, tivesse acesso a uma lista de exposições em que 
poderia criar e editar, tornando também sua curadoria disponível à visualização de outros usuários cadastrados.

Dessa forma, O MAC USP pretende, através de seu portal, aumentar cada vez mais sua visibilidade e disponibilizar dados e informações sobre sua coleção, seja para entretenimento, seja para organizar conhecimento e processo criativo.

Em 2005, o projeto MAC Virtual foi classificado como um dos três melhores Museus OnLine, na categoria "Museu de Arte", pelo júri do INFOLAC WEB $2005^{45}$.

O prêmio é concedido pelo Departamento de Informação das Oficinas da UNESCO em Quito, Equador, e visa contribuir para a capacitação e desenvolvimento de conteúdos na Internet. Os jurados avaliam os sites ganhadores considerando as seguintes características: originalidade na concepção gráfica; clareza na apresentação das informações; qualidade da arquitetura para facilitar a navegação, funcionalidade, rapidez nas páginas e conteúdo.

\subsection{O MAC Virtual Hoje}

Após as fases de concepção, criação, pesquisa, desenvolvimento e implantação do projeto, o MAC Virtual deixou uma herança de acertos e erros em sua elaboração que vale ser mencionada.

A primeira delas é ligada à própria administração do site. Diferente do que se observou na análise do portal da TATE, que é mantido e gerenciado por uma equipe do museu especialmente designada para isso, mas que conta, principalmente, com o suporte tecnológico e financeiro da BT, a administração do site do MAC é, atualmente, uma das atribuições do que é hoje a Equipe Técnica de Imprensa e Divulgação, sob a orientação do jornalista Sérgio Miranda. E, nesse aspecto, a principal deficiência foi no investimento do capital humano. As esquipes que prestaram serviço para a elaboração do MAC Virtual durante o patrocínio do Grupo Santander não tinham vínculo com o Museu, apenas foram contratadas, mas não geraram mão de obra especializada para gerenciar e administrar as questões técnicas ligadas ao portal, o que trouxe uma imensa dificuldade em continuar o projeto, já que este dependia de atualização e manutenção constantes, e depois, a própria equipe técnica do MAC, que não havia participado nem da elaboração do que corresponde à parte tecnológica nem do desenvolvimento da arte e da interface do projeto, não tinham conhecimento no que diz respeito às linguagens de programação, estruturas e recursos, detalhamento técnico e identidade visual.

\footnotetext{
${ }^{45}$ Disponível em http://portal.unesco.org/ci/en/ev.phpURL_ID=20308\&URL_DO=DO_PRINTPAGE\&URL_SECTION=201.html, acesso em janeiro de 2011.
} 
Ainda assim, sob os esforços pessoais do Sergio Miranda e dos profissionais que compõe a equipe do museu, o site vem sendo atualizado com as informações relativas às exposições, cursos, projetos e atividades realizadas pelo MAC para a comunidade em geral. A interface do portal é, hoje, diferente do que fôra concebida para o MAC Virtual. Ela usa cores diferentes do restante do portal, traz menus mais rápidos e de fácil navegação; para a elaboração dessa página, foi criado um template, uma espécie de colagem feita de páginas sobrepostas para facilitar o acesso a conteúdos que já existiam antes do MAC Virtual entrar no ar, mas que não foram aproveitados e incorporados ao projeto.

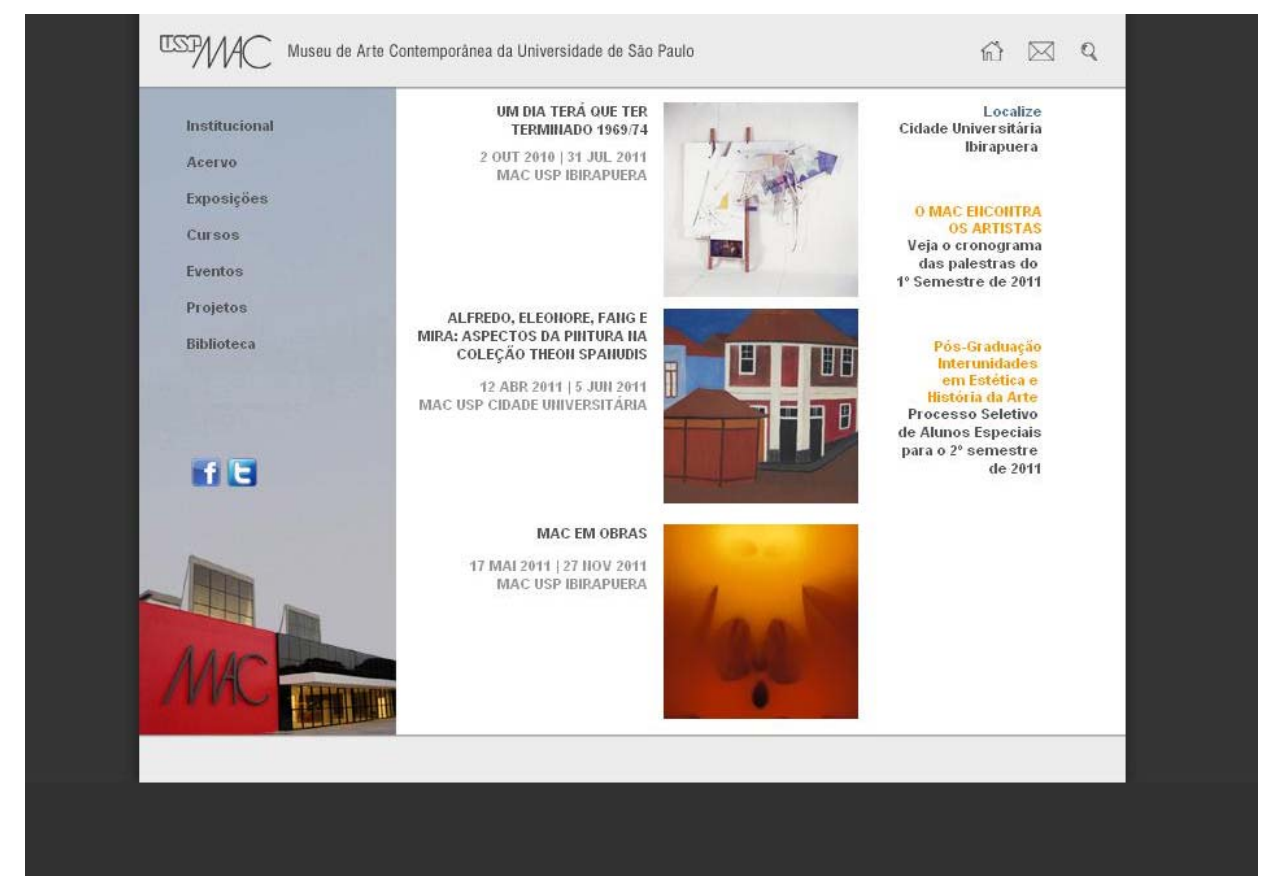

Imagem 17 - Detalhe da página atual de acesso ao portal MAC Virtual

O site tem um serviço de "fale conosco", uma conta de e-mail que é o principal canal de comunicação com o público do site e do próprio museu, administrada por Sérgio Miranda. A partir desse contato com o usuário foram identificados os principais problemas em relação ao portal. Um deles é ligado ao acesso aos conteúdos, os sistemas de busca do site não são claros e dificultam a pesquisa e o acesso às informações. Outro problema está ligado à navegação, mesmo que o visitante saiba que tipo de informação está procurando e esteja familiarizado com a linguagem do museu, ainda assim é difícil navegar pelo site.

A principal necessidade hoje é a criação de um sistema eficiente de buscas e pesquisas e a disponibilização do acervo do MAC na Internet. Das 10 mil obras presentes na coleção do MAC atualmente, apenas 319 têm suas versões digitalizadas, com 355 autores cadastrados. A equipe que trabalhou no projeto MAC Virtual optou por disponibilizar 
apenas as obras que tivessem acompanhadas de textos críticos e biográficos, o que dificultou sua criação.

Outra avaliação feita a partir do feedback dos usuários é a utilização dos recursos ligados ao Museu Lúdico. A maioria das atividades é limitada e repetitiva, não permite grande interação do usuário, além de serem didaticamente criticadas. Há ainda a intenção de tornar o site uma ferramenta mais interativa e abrir espaço para as pessoas se apropriarem do portal de maneira diferente, por meio do uso das redes sociais e criação de blogs, o local onde o usuário poderia fazer seus comentários, cadastrar-se, personalizar sua experiência ao visitar as páginas do museu, além de dar mais espaço às ações para patrocínio e financiamentos dentro do site, traçar um plano com estratégias de marketing que aproximem as empresas interessadas em ligar sua marca à do Museu.

Essas intenções mostram a dificuldade em resolver problemas aparentemente simples sem a aquisição de equipamentos, softwares, contratação de mão de obra qualificada e investimentos.

O projeto do MAC Virtual não estava integrado ao site do museu que já existia antes de 2002. Houve então uma confusão quanto ao endereço do site. Já existia o www.mac.usp.br, e, após o projeto, foi criado o www.macvirtual.usp.br. Hoje, um endereço único é identificado nas páginas de pesquisa da rede, e a versão atual do site do Museu de Arte Contemporânea é, na verdade, uma mistura entre interfaces novas e um conteúdo que, na sua maioria, já estava ali.

Em 2009, durante a segunda gestão da Profa. Lisbeth Rebollo no MAC, foi lançada a revista eletrônica Contemporânea. Pensada para atuar como um espaço de produção e circulação de informação e conhecimentos sobre Arte Contemporânea, a revista inaugura um importante debate sobre onde está o espaço para o discurso crítico e a discussão acerca da produção e do mercado das Artes nos dias atuais. Trataremos de seu desenvolvimento no capítulo seguinte.

\subsection{TATE e MAC: Experiências Virtuais Distantes}

Após a apresentação, realizada ao longo deste capítulo, sobre como as duas instituições museológicas estudadas, TATE e MAC-USP, aproximaram-se do Ciberespaço, como pensam e se comunicam com o visitante, quais recursos, ferramentas e atrativos disponibilizam para se aproximar do público, e em que medida reconhecem o espaço virtual como um local em potencial para o desenvolvimento do discurso sobre arte e formação de público, faz-se necessária uma análise a fim de perceber em quais pontos as duas 
instituições aproximam-se, em quais se distanciam e por que, e quais as possíveis sugestões para se apropriarem do Cibersespaço de maneira efetiva.

Ambas se lançam no Ciberespaço em datas muito próximas. O MAC tem sua primeira versão do site disponibilizado na Internet em 1995, e a TATE em 1998. Apesar disso, logo demonstram entendimentos diversos do real potencial dessa expansão gerada pela rede, e como ela pode se caracterizar como fator de aproximação e formação de um novo tipo de usuário-visitante online.

Em suas primeiras experiências, observou-se que a Internet ainda é tratada como um espaço de comunicação de grande alcance, permitindo, dessa forma, a divulgação das atividades desenvolvidas dentro das instituições, de modo a concentrar mais usuários e possivelmente, mais visitantes para o Museu.

Outro ponto de aproximação das duas instituições é o interesse em disponibilizar todo ou grande parte do acervo em sua versão online na rede, como uma alternativa de exibir, promover e aproximar as coleções dos museus a um público que não teria oportunidade de vê-la, ou, como no caso do MAC, resolver um problema da limitação do espaço físico do museu, que impede a exibição da maior parte de suas obras.

Nesse sentido, retomando a já citada tipologia de sites de museus criada por Piacente, classificamos os sites do MAC e da TATE enquanto museus no mundo virtual, embora o site do MAC aproxime-se mais da categoria folheto eletrônico, dada a preocupação com a divulgação de informações que reforcem aos usuários as atividades, funcionamento e ações desenvolvidas pelo MAC-USP, ou seja, com o possível aumento no número de visitantes do museu.

Posteriormente, com a parceria estabelecida entre TATE e BT, e com o patrocínio do Grupo Santander e o desenvolvimento do projeto MAC Virtual, os museus começam a caminhar em direção a um maior entendimento do que se pretende ao ocupar esse novo espaço.

No que diz respeito ao conteúdo e à informação sobre arte disponibilizada em suas páginas, observou-se uma grande diferença entre eles. Embora em muitos casos o ponto de partida seja as questões relacionadas às suas coleções, elas diferem, primeiro, na quantidade de informação produzida e veiculada nos sites, em suas páginas. A TATE mantém, como já demonstrado, seções direcionadas à pesquisa e produção de conteúdos em Artes realizada por funcionários do museu, e também por pesquisadores independentes, acadêmicos, estudantes e profissionais de outras instituições que se debruçam sobre os temas que envolvem a coleção TATE: arte britânica a partir dos anos 1500 e arte moderna e contemporânea internacionais. Além das páginas dentro do portal, há links para blogs e conteúdos em que podem ser vistas entrevistas e depoimentos de curadores, críticos e artistas, somados aos arquivos de vídeo e imagens das obras, divulgando, além de sua 
produção interna, um panorama sobre a História e Crítica de Arte a partir do seu acervo. Já o material encontrado no MAC Virtual diz respeito quase que totalmente à produção de textos criados na ocasião do desenvolvimento do projeto do site, que acompanha a digitalização das 240 obras disponíveis no acervo online do museu ainda hoje.

Outro problema é a distribuição dos conteúdos. No portal TATE Online os textos aparecem em várias seções, ligadas à exposição em cartaz, aos núcleos de pesquisa e difusão do museu, como versões online das publicações impressas desenvolvidas pela instituição, como é o caso da revista TATEETC., onde fica sempre claro sobre quais das cinco galerias da TATE é a informação e quem assina o texto, ou seja, a participação do usuários através de comentários, citações e indicações bibliográficas é estimulada, mas é separada da opinião da instituição e seu posicionamento enquanto produtora e gestora da informação sobre Arte que veicula em suas páginas. O site do MAC, como já foi dito, apresenta a produção de conteúdos ligados às poucas obras digitalizadas em seu site, os textos foram produzidos pelos docentes e pesquisadores do museu, e, atualmente, ao acessar o menu Exposições encontramos, no item referente ao ano de 2011, links de acesso às paginas das exposições em cartaz, que contém alguns textos curatoriais e informações mais detalhadas das obras e seu contexto em questão.

Outro aspecto relevante para essa análise é a evolução da linguagem da interface dos portais. Com as mudanças nas diretrizes e no entendimento das funções dos sites, as interfaces e as páginas de acesso ao portal onde o visitante comunica e interage com o site também mudam. No caso da TATE, o portal apresenta hoje cores atrativas e em harmonia com relação à marca TATE, que se diferenciam dentro do site servindo como forma de localização do visitante, ou seja, a cada área corresponde uma cor diferente. Além disso, a navegação é facilitada pela disposição dos menus e distribuição de links e serviços disponíveis.

$\mathrm{Na}$ parte superior, além do acesso rápido às quatro galerias TATE, há oito menus superiores, destacando, além da coleção, os espaços para a compra de ingressos, loja, doação e blog. O foco do site é sempre o usuário, a utilização de recursos tecnológicos mais dinâmicos torna a experiência do visitante mais interativa; ele escolhe por quais páginas quer navegar e em quais quer se aprofundar, o site permite e reforça essa autonomia do visitante em relação aos conteúdos disponibilizados.

O MAC Virtual é um site mais hermético. Como já se notou, sua navegação é prejudicada por alguns problemas na diagramação e estruturação das páginas em seu interior. O principal deles é a criação de páginas sobrepostas, usadas como alternativa à necessidade de atualização dos conteúdos presentes no site que não haviam sido utilizados pelo projeto inicial do MAC Virtual. Essa abertura de várias janelas sequenciais, além de confundir o usuário, tende a fazer com que ele perca o foco e o interesse pela navegação. 
Como a navegabilidade não é uniforme, encontramos diferença na diagramação, uso de cores, fontes de textos, menus de recursos e serviços e padrões diferentes.

Hoje, a página inicial apresenta uma identidade visual diferente do restante, o que gera ainda mais problemas quanto à identificação do usuário em relação ao site. Seria possível também uma melhor utilização das cores para diferenciar as três áreas do portal, o Museu Universitário, Lúdico e Experimental. Atualmente, o visitante transita entre um e outro sem perceber que está mudando e por que aquele conteúdo faz parte de determinada seção e não de outra.

Além disso, o site da TATE tem um posicionamento mais ativo em relação ao funcionamento da instituição e seu perfil enquanto agente de transformação e reconhecimento cultural da cidade e seu entorno. São constantes as ações realizadas pela TATE, e que tem seus desdobramentos no portal, para conhecer e se aproximar de seu público, e reforçar a marca da instituição junto ao público. Realiza pesquisas e consultas sobre a satisfação do usuário, oferece uma área onde o visitante pode se cadastrar e interagir com os recursos de acordo com suas necessidades, além de promover muitas ações que acontecem apenas no portal, disponibilizando recursos e ferramentas que incentivam a busca por informações sobre Arte. Importante salientar que com o número de atualizações mensais realizadas em ambos os sites, o portal da TATE aparece como uma ferramenta mais ágil e constantemente atualizada, o que estimula a visita e a busca por informações.

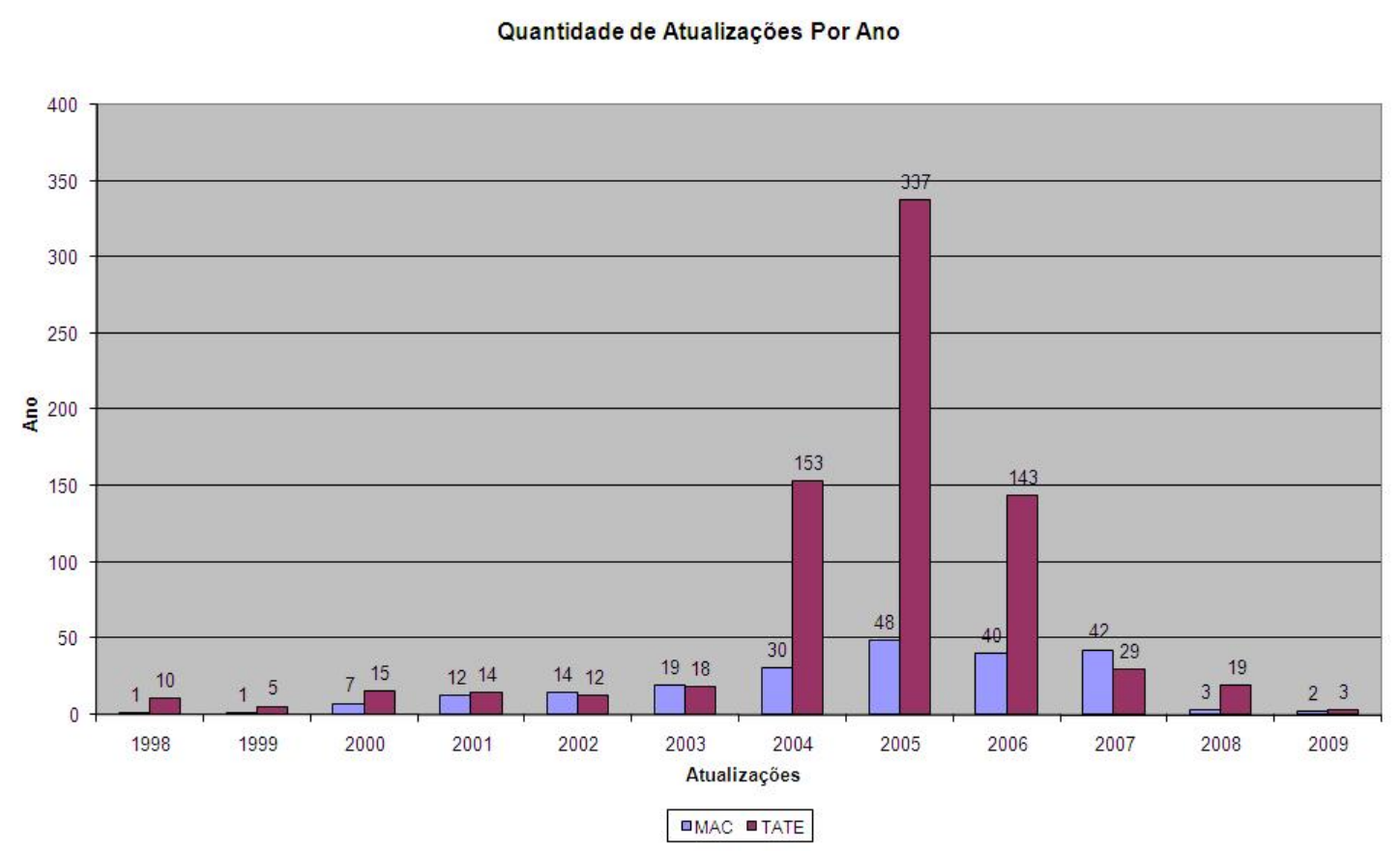

Imagem 18 - Gráfico representando acessos entre 1998 e $2009^{46}$

\footnotetext{
${ }^{46} \mathrm{O}$ gráfico indica o número de vezes que os sites www.tate.org.uk e www.mac.usp.br foram atualizados.

O rastreio é feito pelo Wayback Machine, site que monitora atualizações. Disponível em http://waybackmachine.org/19990515000000, acesso em dezembro de 2010.
} 
Nesse aspecto, há uma grande diferença entre os recursos interativos e de aprendizagem disponibilizados pelos dois portais. O MAC Virtual, em seu espaço intitulado Museu Lúdico oferece recursos com baixo nível de interação do usuário, apresentando de forma limitada e cansativa, um pequeno recorte das obras em sua coleção, recomendado para crianças com faixa etária não superior a sete anos.

Já a TATE Online oferece recursos organizados e separados por faixas etárias, com interface e uso de recursos adequados a cada idade, que estimulam a continuidade de navegação, o conhecimento do acervo e a publicação de comentários sobre os trabalhos e os serviços do site.

No que diz respeito à pesquisa de informações e opções, o MAC Virtual tem sua ferramenta de busca voltada apenas para as questões relacionadas às obras do acervo, enquanto que a TATE Online amplia as buscas para todas as seções do site. Outra diferença é a comunicação que o visitante pode estabelecer com a instituição. O MAC possui apenas uma conta de e-mail que é relativa a todas as questões que envolvem o museu, já na TATE encontramos o nome e endereço eletrônico dos responsáveis por cada área ou tema, direcionando o usuário e potencializando o alcance da comunicação.

A TATE coloca em posição de destaque no site e em suas ações de mídia externa, a importância da parceria com a BT e do espaço para a participação do visitante em se tornar sócio ou patrocinador do museu. Essas ações mostram a importância dada pela instituição em promover parcerias e trocas com a comunidade.

Outra hipótese levantada no início desse estudo era se a Internet, devido ao seu alcance, relativa facilidade de acesso, baixo custo de manutenção e rápida velocidade de transformação e readequação dos recursos seria um espaço mais democrático na equiparação entre instituições com perfis de gestão e financiamento distintos, como é o caso do MAC e da TATE. Na verdade, verificou-se que a Internet não soluciona os problemas e barreiras encontradas no âmbito presencial. Ela é direcionada pelas virtudes e limitações da instituição. A velocidade e facilidade em seu acesso não garantem um espaço de saber e construção de conhecimento sobre Arte mais democrático, porque sua construção é feita junto com o usuário. Ao chegar até aqui, verificou-se que o que mantém e solidifica a comunicação entre a instituição e o usuário é o reconhecimento que este tem em sua marca e seu perfil.

Com o alcance da rede, o usuário não espera encontrar no site instruções, amostras ou informações do que ele pode vir a conhecer ao visitar o espaço físico da instituição, a navegação no site é a própria experiência de visita ao museu sob outra perspectiva, sem a pretensão de recriar o ambiente de paredes e galerias do museu, mas com a participação 
de outro tipo de espectador, o internauta. E o espaço virtual é o lugar ideal para promover esse reconhecimento estimulando as trocas e interações entre ambos.

Esses são alguns dos diferenciais do site da TATE em relação ao MAC. Apesar de terem surgido na mesma época, após um pequeno período de experimentações e investigações acerca do potencial do Ciberespaço, a TATE rapidamente mudou seu foco. De informação, a palavra passou a ser interação. E essas mudanças só aconteceram devido a uma série de diferenciais que o portal da TATE apresenta em relação ao MAC Virtual:

- Patrocínio da BT: além de apoio financeiro oferece também soluções tecnológicas e de hospedagem do site;

- Equipe destinada a cuidar das questões relativas ao site: assim como as outras quatro galerias TATE têm sua equipe de gestores e profissionais técnicos, o portal também possui um grupo de pessoas preparado para tratar de suas questões específicas;

- Plano de metas para o site: assim como acontece com toda a instituição, o site responde a um plano de metas e estratégias que levam em conta o perfil de seus usuários, conteúdos e serviços disponíveis online e o próprio crescimento da instituição;

- Integrar o site à missão da instituição: o site deve ser reconhecido como a quinta galeria TATE, onde também são aplicados os valores e a missão da instituição;

- Diferencial: preocupação com o tipo de recurso e conteúdo online e com a formação do público virtual;

- Interação/participação do usuário: tornar a experiência de visita ao site cada vez mais única e personalizada;

- Investigação do público e suas necessidades: preocupação em conhecer cada vez mais os usuários e seus perfis.

Diante desse panorama, pode-se perceber que o portal TATE Online caminha na direção de estabelecer-se, de acordo com a classificação de Piacente, como um museu realmente interativo, com sua correspondência no mundo físico e com questões ainda bastante ligadas ao desdobramento de suas coleções, mas que já reconhece o Ciberespaço enquanto ponto nodal da sociedade contemporânea, e que precisa ser ocupado pela Arte e pela Cultura de maneira a estreitar e romper com os ruídos nos discursos sobre Artes facilitando a comunicação com o museu e seu público, seja ele no espaço presencial da sala de exposição ou no espaço virtual dos blogs e trabalhos online. 


\section{CAPÍTULO 3 \\ CONHECIMENTO SOBRE ARTE NO CIBERESPAÇO}




\subsection{TATEETC. e Contemporânea: espaços para o debate sobre Arte além dos sites}

Em outubro de 2002, a TATE iniciava sua publicação de revistas especializadas em conteúdos sobre Arte. Surgia no mercado a TATE Magazine, publicada pela Condé Nast Publications. Até dezembro de 2003 foram oito números abordando diversos temas sobre a história da arte, tendo como pano de fundo a programação da instituição, além de informações sobre o circuito e o mercado de artes internacionais, entrevistas com artistas e críticos, textos sobre moda, arquitetura e um panorama da arte contemporânea mundial. Por ser uma revista idealizada para a versão impressa, atualmente estão disponíveis no portal TATE Online apenas alguns números e artigos para consulta.

A partir de janeiro de 2004, a TATE assume a publicação da revista, que passa a se chamar TATEetc. Assume também como diretora-chefe a jornalista Bice Curiger, responsável pela fundação da revista de arte contemporânea Parkett ${ }^{47}$, além de realizar uma série de publicações entre catálogos e monografias de artistas.

A TATEETC. é uma revista pensada e diagramada para a impressão, publicada três vezes por ano, em janeiro, maio e setembro, e seu conteúdo e estruturação coincidem com o calendário anual de programação da instituição.

Era inicialmente distribuída aos membros e associados do museu e em livrarias e instituições culturais, com uma tiragem de 55 mil exemplares. Hoje, a TATEETC. está disponível em 16 países da Europa, América do Norte, Ásia e Oceania, em uma tiragem de mais de 95 mil exemplares que atende a assinantes nacionais e internacionais, membros da instituição, curadores, pesquisadores, além de estar disponível em livrarias e pontos de venda especializados em publicações voltadas para as Artes Visuais.

A escolha dos temas e informações publicadas a cada edição é feita levando-se em conta o calendário de exposições da TATE. A partir de uma reunião entre o Conselho Editorial da revista e os curadores e pesquisadores da instituição, são decididos quais os possíveis assuntos a serem tratados, e quais profissionais de referência serão convidados para assegurar a credibilidade da informação. Dessa forma, $60 \%$ do conteúdo da publicação é baseada na programação da TATE ou em projetos realizados pela instituição em parceria com grupos de artistas e outros museus, e os outros $40 \%$ são ensaios, entrevistas, e matérias que contemplam a História da Arte e acontecimentos atuais dentro do circuito da Arte.

\footnotetext{
${ }^{47}$ Revista internacional de Artes Visuais publicada duas vezes por ano, em inglês e alemão, com colaboração direta de importantes artistas internacionais. Com uma tiragem de cerca de 10 mil exemplares, é lida por cerca de 30 mil pessoas em 40 países. Disponível em http://www.parkettart.com/cont_intro.htm, acesso em maio de 2011.
} 
Como o próprio nome sugere, a TATEETC. apresenta abordagens originais aos assuntos já amplamente discutidos dentro da História da Arte. Sua missão é deixar o debate sobre Arte mais interessante ao explorar o contexto de suas coleções, sua história e significados. Misturando fatos históricos, entrevistas e o cenário das Artes Visuais em escala internacional, a revista traz o debate para a cena contemporânea projetando os temas e contextos da Arte para além dos limites das suas galerias e coleções.

Ela é, essencialmente, uma publicação impressa, embora tenha disponibilizada, dentro do portal TATE Online, sua versão digitalizada em que se pode acessar todos os artigos e edições já lançadas.

A ideia de lançar na rede todo o conteúdo digital da revista está ligada à missão da instituição, de tornar a Arte disponível a um número cada vez maior de pessoas, ampliando seu alcance. Desde 2006, a revista disponibilizou, para o público em geral, a assinatura de um ou dois anos da revista. Esse serviço pode ser adquirido através do portal TATE, assim como a compra de edições anteriores desde o seu lançamento, que estão disponíveis dentro da seção ligada à loja online ou podem ser adquiridos conectando-se a um endereço de e-mail e solicitando os exemplares.

Todo a informação é disponível em inglês, em um menu de acesso rápido e de destaque dentro do portal. Como, atualmente, a maior parte da receita da instituição, cerca de $60 \%$, vem da doação de patrocinadores, associações, fundações e membros individuais, a ideia da TATE não é obter lucro com a revista, podendo, dessa forma, disponibilizar todo seu conteúdo gratuitamente na rede sem que haja a necessidade do usuário inscrever-se ou estar ligado de alguma forma ao museu.

A TATEETC. hoje configura-se como uma das principais revistas ligadas às Artes Visuais da Europa e que tem seu alcance potencializado pela inserção na rede. Experiência diferente da observada pela revista Contemporânea, do MAC-USP.

Lançada em novembro de 2009, a Contemporânea foi pensada para ocupar e funcionar dentro do Ciberespaço, levando em consideração suas questões específicas e os recursos disponíveis que poderiam ser associados à revista online.

De responsabilidade do jornalista Sérgio Miranda, da Equipe Técnica de Imprensa e Divulgação do MAC-USP, a revista responde a uma demanda da instituição: a de organizar e ampliar a divulgação de textos e artigos produzidos pelo museu, o que não era possível dentro do portal MAC Virtual.

Durante a segunda gestão da Profa. Lisbeth Rebollo Gonçalves no MAC-USP, no período de 2006 a 2010, surgiu a ideia de criação da revista online. De acordo com Sérgio 
Miranda ${ }^{48}$, a revista seria uma espécie de subproduto do site, um espaço que funcionaria como um blog onde o leitor teria um espaço para a participação por meio de comentários e onde seriam inseridos os conteúdos produzidos pela equipe de docentes e pesquisadores do museu. Ele aponta, como questões fundamentais para a constituição do projeto: a instituição de um Conselho Editorial, a elaboração de um portal e a tradução dos conteúdos para outros idiomas.

Desde o início, a orientação da revista é a de falar sobre as atividades desenvolvidas pelo museu e sobre as questões ligadas à Arte Contemporânea que estão sendo discutidas no cenário nacional e internacional, pontuando o MAC enquanto incentivador e fomentador do debate ligado às questões relacionadas às Artes Visuais. Para isso, a ideia era contar com a colaboração dos docentes e funcionários da instituição, mas também com convidados que elaborariam artigos, entrevistas e resenhas para a revista.

Sérgio Miranda comenta a importância da elaboração de uma publicação especializada em Artes Visuais:

\begin{abstract}
"De alguma maneira, uma publicação do próprio museu poderia escolher de que forma passar para o público essas informações. Mas não é só isso. Eu acho que o Museu tem um papel importante de liderar essa discussão. Como é que está a Arte Contemporânea? O Mercado da Arte? O que é Arte hoje? O que vale a pena e o que não vale? Isso não está no jornal do dia a dia. Os cadernos de cultura, cada vez mais, são quase que agendas ${ }^{49,}$.
\end{abstract}

Por ser uma revista sem financiamento, o que limitaria a publicação de imagens e a encomenda de textos específicos, a instituição do Conselho atribuiria maior credibilidade e valor acadêmico e institucional à publicação, ajudando, inclusive, em uma futura busca por patrocínio e continuidade do projeto.

Outra questão é a concepção da revista, em um segundo momento, enquanto uma espécie de portal em que, além do conteúdo desenvolvido, haveria espaço para a participação do internauta. Essa demanda vem das dificuldades encontradas no MAC Virtual e a publicação online se constituiria como esse local de produção e troca de conhecimento com o usuário.

O desenvolvimento do projeto no que diz respeito à diagramação e ao design da revista foi concebido pela empresa Din Digital. ${ }^{50}$.

A primeira diferença em relação às publicações que encontramos disponíveis no espaço virtual e que são, na verdade, versões digitalizadas de conteúdos impressos, como é o caso da TATEETC., é no que diz respeito à sua apresentação. A Contemporânea não

\footnotetext{
48 MIRANDA, Sérgio. Entrevista a Sabrina Popp Marin na sede do MAC USP (Pesquisa de mestrado do Interunidades - USP - Programa de Pós-Graduação em Estética e História da Arte). São Paulo: arquivo pessoal, realizada em 11/12/2009.

49 Ibidem.

${ }^{50}$ Estúdio de Desenvolvimento Web, Design e Computação Gráfica.
} 
apresenta barra de rolagem, ela utiliza um recurso conhecido como page flip, que simula a ação de "virar a página", trazendo a sensação de manusear um documento físico.

Outra diferença está na diagramação dos conteúdos e imagens dentro da revista. Ela se assemelha às revistas impressas no que se refere às caixas de texto e imagens, mas com diferenciais que só podem ser encontrados no espaço virtual, como vídeos com entrevistas e apresentação de imagens em forma de slides. Na página inicial da revista encontram-se também cinco menus de navegação que permitem a visualização da capa, do índice e busca direta por páginas, bem como dos recursos de versão para impressão de conteúdos e um espaço para contato, feito por intermédio de uma conta de e-mail.

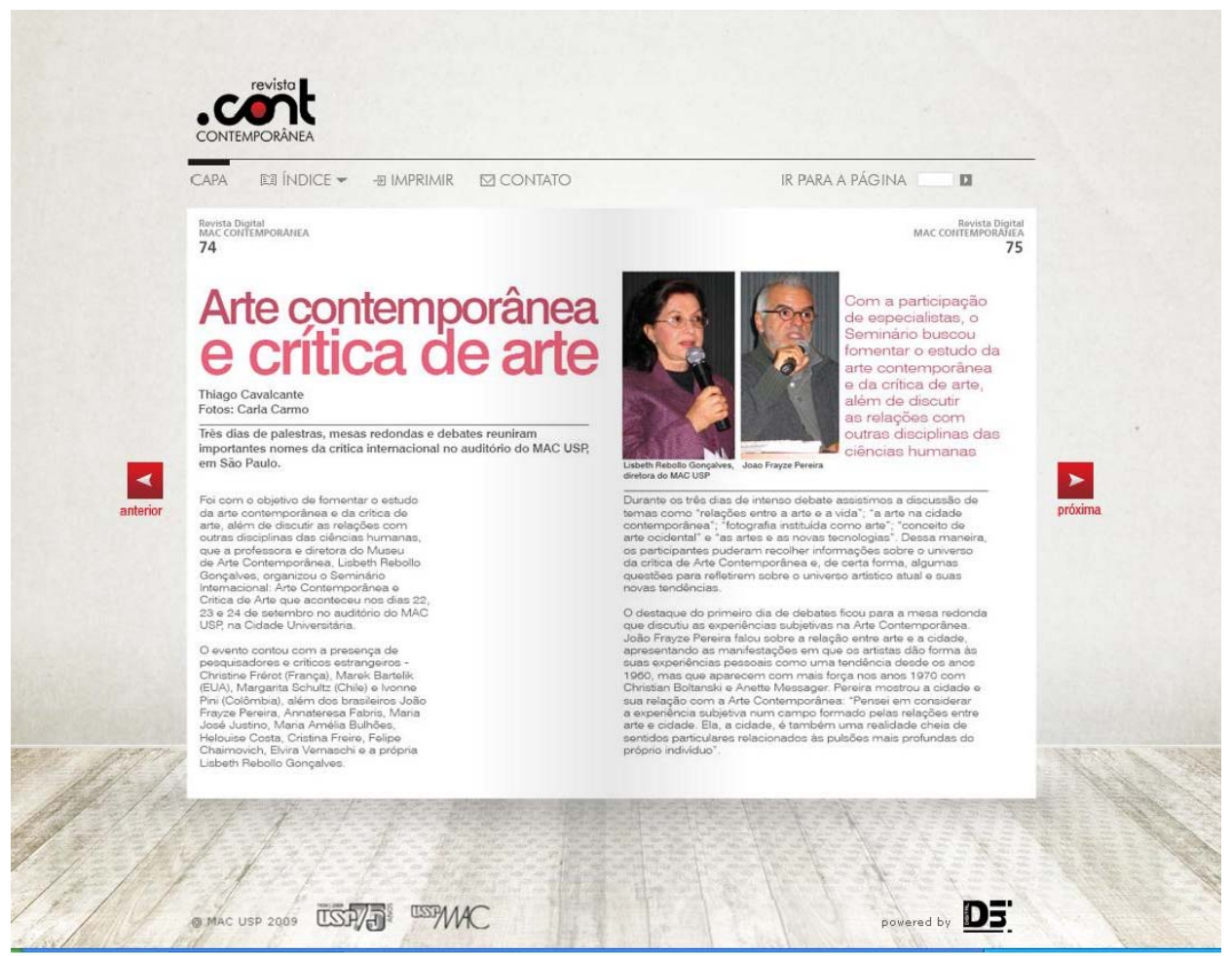

Imagem 19 - Detalhe da matéria "Arte Contemporânea e crítica de arte" disponível na revista digital Contemporânea

Sobre as possibilidades que a publicação online permite, Sérgio Miranda comenta:

\begin{abstract}
"A maioria das revistas de museus fez um caminho inverso do nosso, elas têm a revista em papel, que nós não temos, e colocaram à disposição na Internet. Assim, não tem muito como ser de outro jeito, porque a revista em papel não tem o vídeo, o som...as pessoas podem imprimir, chegar mais perto, mas não dá para fazer muito mais coisa do que isso. A nossa não é. A ideia é usar o que o meio te permite." ${ }^{51}$
\end{abstract}

\footnotetext{
51 MIRANDA, Sérgio. Entrevista a Sabrina Popp Marin na sede do MAC USP (Pesquisa de mestrado do Interunidades - USP - Programa de Pós-Graduação em Estética e História da Arte). São Paulo: arquivo pessoal, realizada em 11/12/2009.
} 
Outra vantagem é em relação à liberdade que se tem para planejar, programar e lançar a revista online, que não depende dos prazos de impressão e distribuição que são necessários às publicações impressas.

Em seu primeiro número, a Contemporânea foi divulgada através de um e-mail enviado ao mailing de contatos do museu, nota de imprensa, e teve sua capa inserida na página principal do MAC Virtual.

Essa edição apresentou, como tema de abertura, "Arte Sem Medidas", que tinha como cenário o programa de exposições em cartaz no MAC-USP e na cidade de São Paulo, e contou com a colaboração de especialistas consultados e pesquisadores do próprio museu.

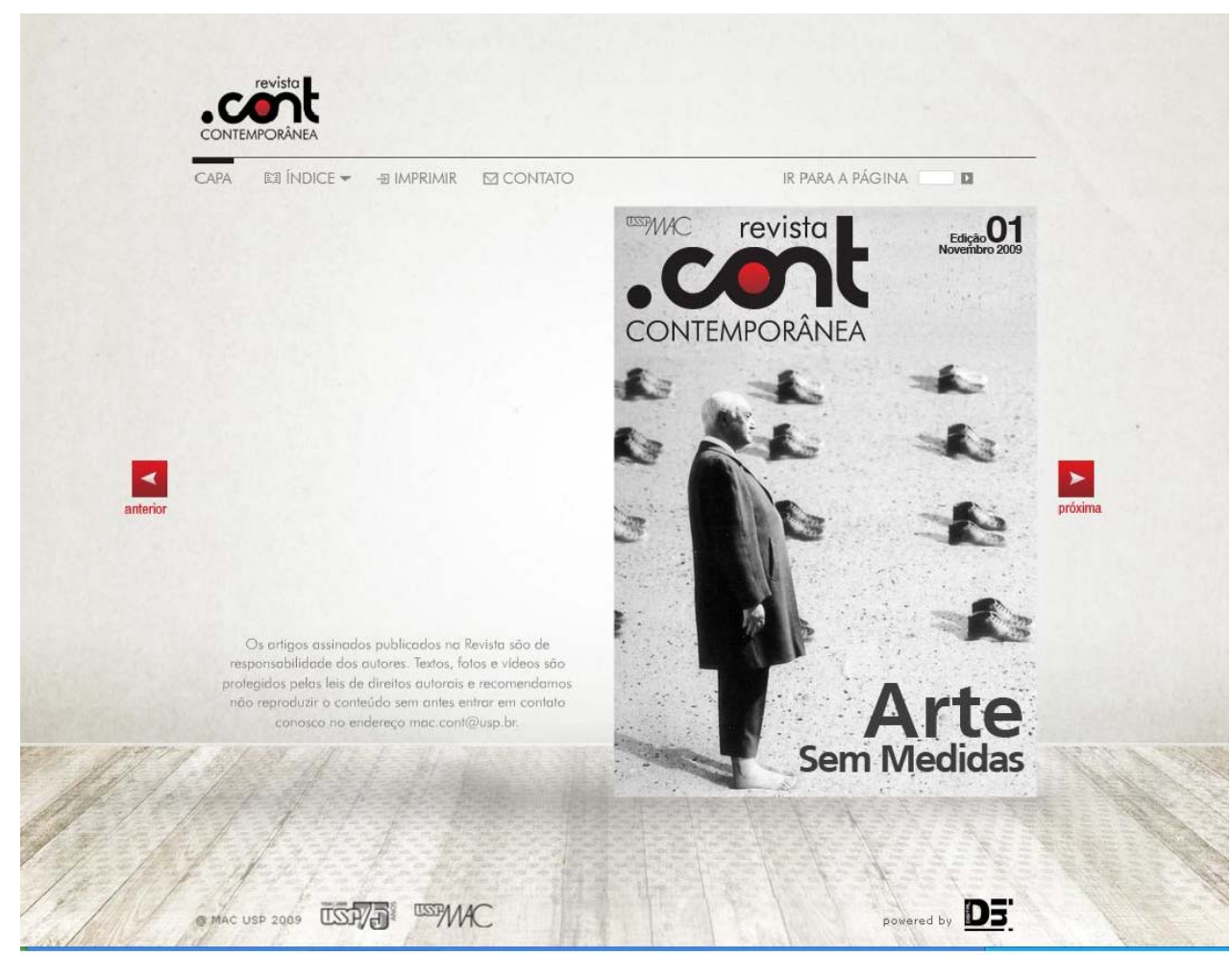

Imagem 20 - Detalhe da página inicial da revista Contemporânea

A edição de um segundo número da revista estava prevista para março de 2010, mas não se concretizou. Com a mudança na gestão do Museu, o novo diretor optou por não continuar, nesse momento, a publicação da revista, priorizando outras ações.

Com apenas um número lançado, a Contemporânea teve importância na abertura de um debate que se faz emergente na sociedade da informação em que vivemos. Em que medida essas publicações virtuais poderiam ser uma alternativa para instituições que não possuem financiamento para lançar revistas impressas? E que tipo de debate elas trazem para o cenário das Artes e Cultura no panorama atual? Com a proposta da revista, o museu coloca-se como produtor e incentivador desse debate, das questões em torno da Arte 
Contemporânea e do estímulo à participação e colaboração dos leitores/internautas que extrapolam os limites físicos de seu espaço expositivo e coleção, e ganham o Ciberespaço, mais um lugar para o debate, a crítica e a produção em que as Artes Visuais passaram a habitar.

\subsection{Diferentes concepções para um mesmo tema}

Diante do exposto, percebe-se que as duas publicações analisadas foram, inicialmente, concebidas para funcionar em espaços e mídias diferentes. A TATEETC. é uma revista impressa, que tem seu conteúdo disponibilizado na rede, como forma de facilitar e ampliar seu acesso. Essa adaptação, a transposição dos conteúdos e imagens que apresenta uma configuração no projeto impresso para a versão online tem algumas limitações.

A primeira é a extensa barra de rolagem que se forma ao navegar por alguns artigos. Como não há a configuração semelhante às páginas impressas, os arquivos de textos e imagens são organizados de forma corrida, gerando uma página longa e que pode desestimular a leitura.

Quando o espaço da revista é acessado, por meio de um link direto dentro do portal, encontramos uma página que mostra a edição atual, e o que seria sua matéria de capa em posição de destaque. Na lateral esquerda, um menu de navegação exerce a função de índice exibindo todos os conteúdos disponíveis naquela edição. 


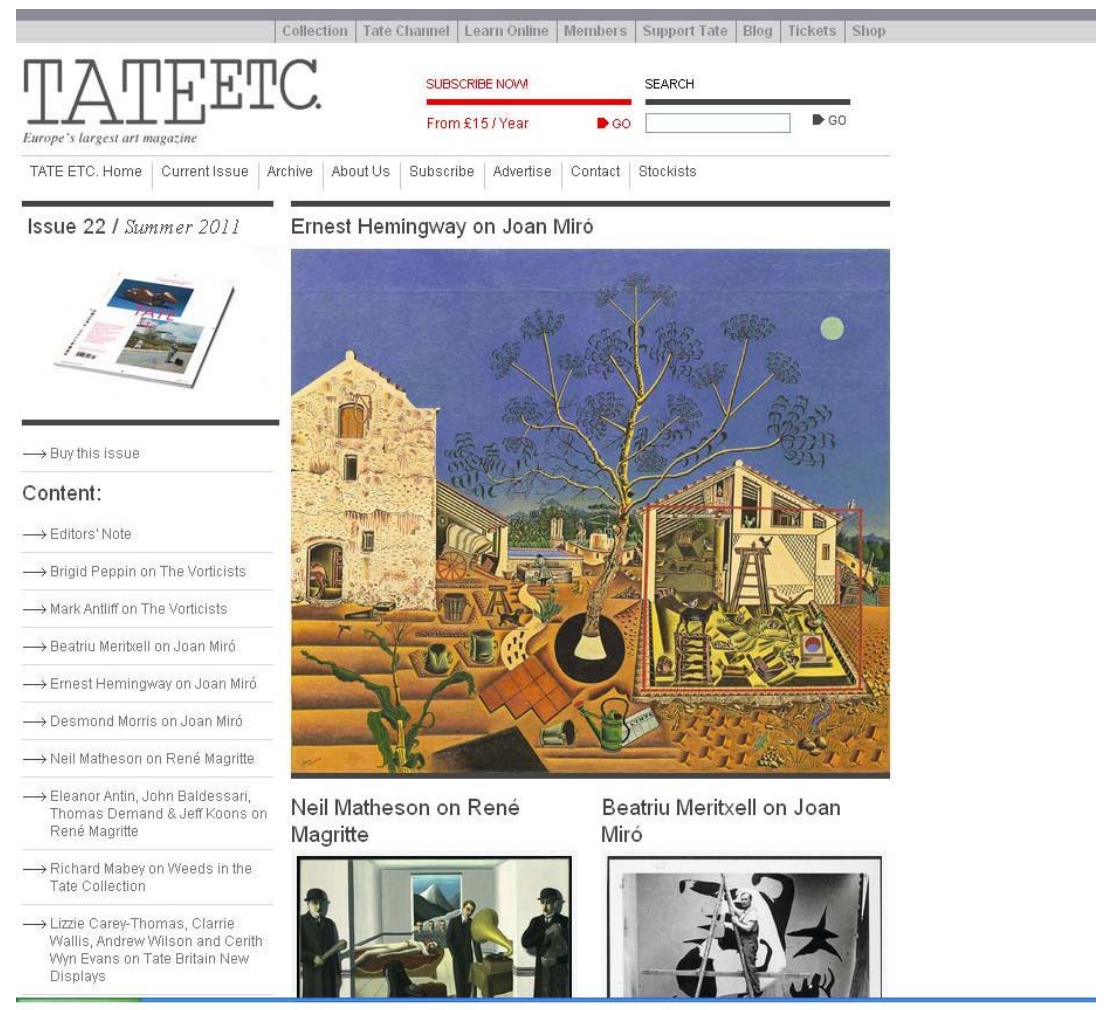

Imagem 21 - Detalhe da página inicial do número 22 da TATEETC.

$\mathrm{Na}$ parte superior da página, outro menu de navegação oferece as opções para acessar as edições anteriores, realizar a assinatura da versão impressa, contatos, anúncios e informações sobre distribuidores em diversos países. É importante notar que a página da revista está inserida no portal TATE e, como em todas as seções visitadas, há sempre menus fixos que oferecem o recurso de voltar para a página inicial ou acessar diretamente os espaços das outras quatro galerias. Essa ligação com o portal facilita a navegação do usuário na medida em que evita a abertura de muitas janelas; o usuário reconhece essa página como parte do conteúdo da TATE e não como um espaço onde é direcionado para outro lugar dentro da rede.

Além disso, apesar de não se constituir enquanto revista digital, a TATEETC. soube utilizar alguns dos recursos online como forma de estimular o acesso. Com relação aos conteúdos, as mesmas matérias estão disponíveis em ambas as versões, o que difere é sua diagramação e o fato de, em alguns casos, haver uma modificação na posição e número de imagens da revista impressa para a versão online.

Outro recurso encontrado pela TATE é o de associar, através de links, à matéria que está sendo exibida uma espécie de "contexto" em que ela aparece dentro da instituição, como exposições em cartaz, obras em acervo ou outros eventos em que o tema abordado tenha sido discutido dentro das práticas e ações do museu. 


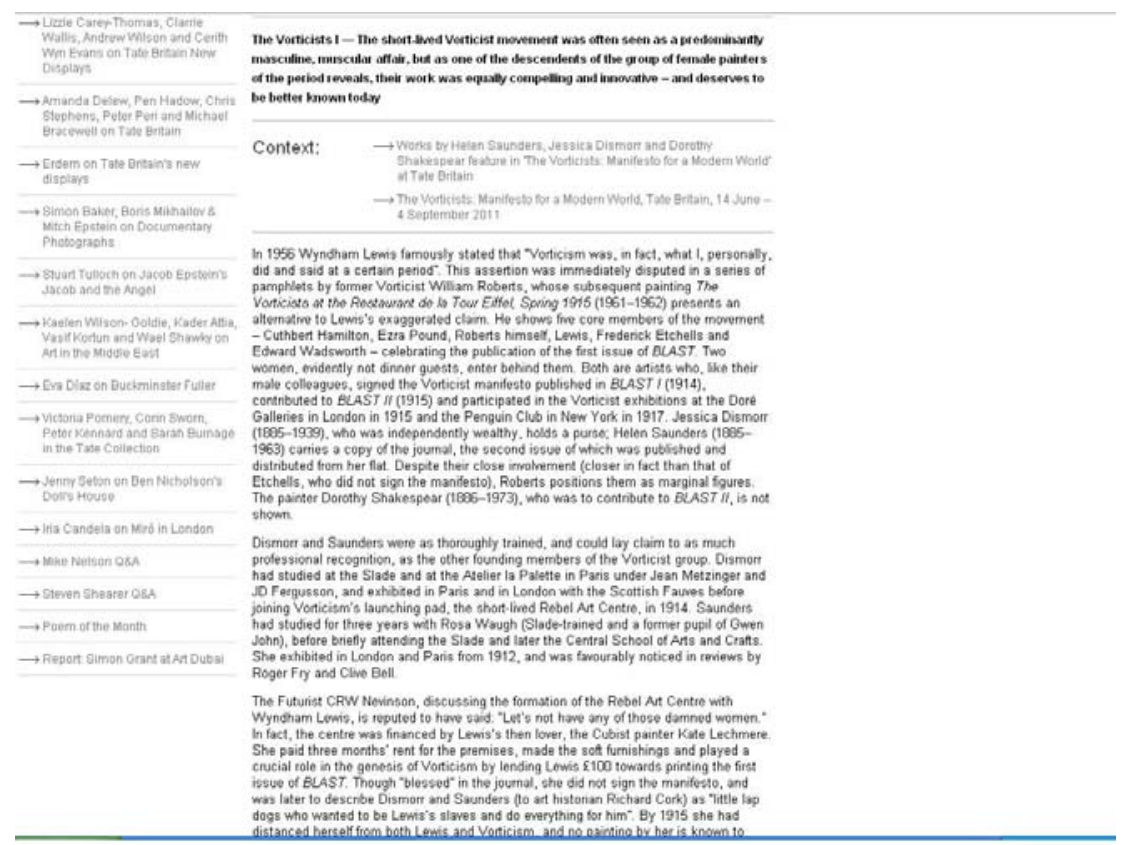

Imagem 22 - Detalhe da página da TATEETC. com destaque para o contexto em que o assunto tratado aparece no acervo TATE

Os principais diferenciais em relação à versão digital é que ela não possui os anúncios publicitários da revista impressa, apenas a parte destinada às matérias. Além disso, em algumas edições pode-se encontrar conteúdos disponibilizados exclusivamente nas páginas virtuais, como entrevistas, resenhas e comentários de livros ou atividades relacionadas ao circuito das Artes Visuais.

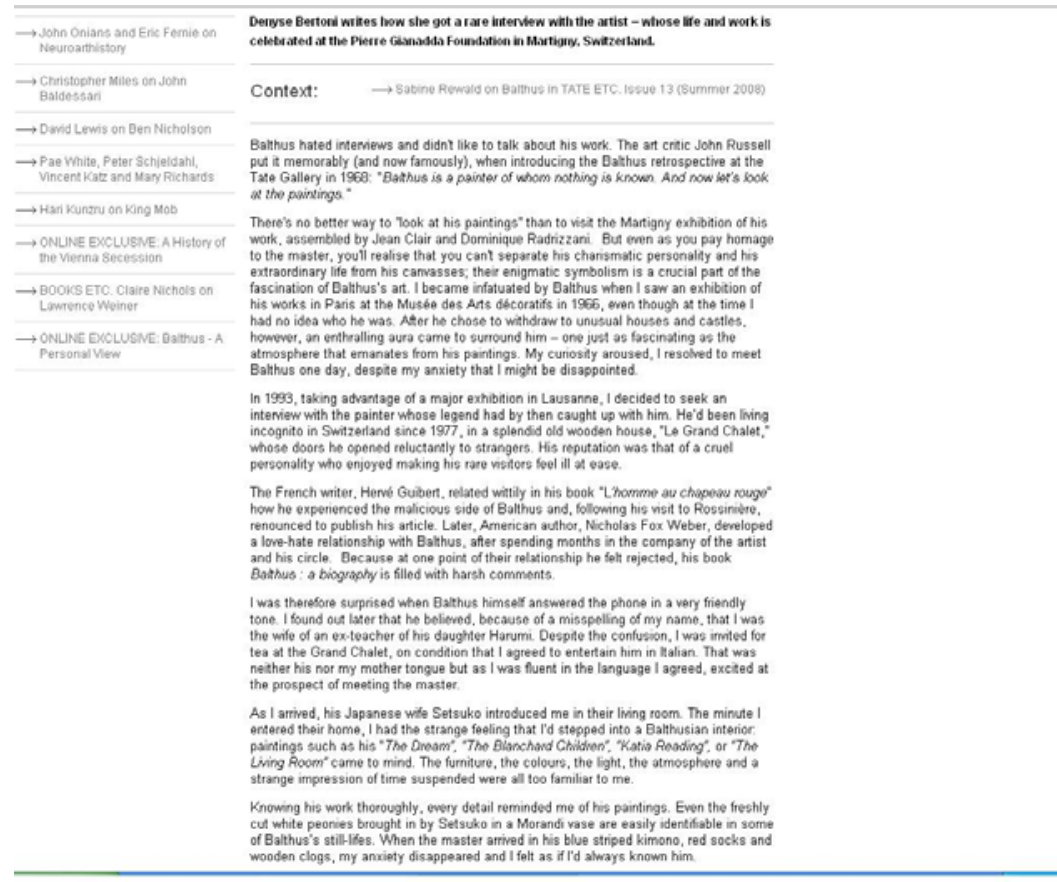

Imagem 23 - Detalhe do conteúdo exclusivo disponibilizado apenas na versão online da revista TATEETC. 
Em relação à revista Contemporânea, que segue o caminho inverso, suas páginas foram pensadas e diagramadas para a leitura na tela do computador. Sua interface é interativa, simula o trocar de páginas da revista, e contém alguns recursos de vídeo e exibição de imagens em formato de slides que torna a leitura mais agradável e dinâmica.

Logo após seu lançamento, foi disponibilizado no portal MAC Virtual um link para acesso direto à revista. Nesse acesso abria-se outra janela de navegação, pois os conteúdos não estavam integrados ao site.

Como a revista publicou apenas um número, não houve tempo para constituir um Conselho Editorial, que seria fundamental para pensar sobre as questões ligadas ao conteúdo, temas, calendário e autores e pesquisadores convidados.

O que se observa, a partir das duas experiências analisadas é que ambas nascem da necessidade da instituição comunicar-se com o púbico e divulgar suas ações enquanto agentes culturais de promoção, divulgação e reconhecimento do patrimônio artístico.

Quem fala ao leitor é um profissional ligado ao museu ou algum convidado que recebe sua chancela para tratar daquele assunto.

Diante da perda de espaço para o exercício da crítica de arte no meio impresso observada nos últimos 40 anos, as revistas TATEETC. e Contemporânea constituem-se como importantes agentes de formação e promoção da atividade crítica, seja pela divulgação de textos e estudos referentes às suas coleções, pela participação de profissionais de referência no campo das Artes Visuais e da Cultura, ou pelo estímulo ao conhecimento e ao debate constantes.

O fato de ambas as revistas serem acessadas no espaço virtual demonstra um reconhecimento, por parte das instituições, do meio digital como espaço potencializador de ações e relacionamento com o usuário. Mas, ainda assim, o fato de estarem na rede não garante seu acesso. Há uma grande quantidade de informações relacionadas às Artes Visuais encontradas em blogs, sites e redes sociais que entram na rede todos os dias. É o fato do leitor reconhecer na instituição sua marca, identificando-a como espaço de credibilidade, que atesta e valida as informações e conteúdos sobre Artes divulgados.

Outra diferença seria na percepção de seu funcionamento enquanto espaço de construção compartilhada. Espaço em que o canal de comunicação com o leitor, tão comumente encontrado nas publicações impressas como jornais e revistas, seria potencializado pela velocidade, distribuição e alcance que as informações ganham ao entrar na rede. A participação mais efetiva poderia estimular o internauta a visitar mais de uma vez o site, atraindo também novos públicos e reconstruindo, a partir de links, imagens e textos, a matéria publicada. 
Ainda assim, esse patamar de interação com o usuário não foi estabelecido, efetivamente, por nenhuma das duas publicações, o que pode demonstrar certa dificuldade por parte das instituições em se relacionar com o internauta quando se trata de publicações no espaço virtual, onde as respostas são rápidas e podem ultrapassar os limites da crítica cultural exercidos pela instituição. 


\section{CONSIDERAÇÕES FINAIS}

Os parâmetros estéticos e de reflexão sobre a ocupação dos museus no espaço virtual está modificada.

Cada vez mais o posicionamento dos museus frente às transformações ocorridas na sociedade da informação, na qual vivemos, é questionado.

Este estudo procurou identificar de que maneira dois importantes museus de arte ocupam o Ciberespaço e como essa ocupação pode refletir na maneira com a qual estamos acostumados a nos relacionar com as obras no espaço museológico.

O primeiro fato que se observou é que a manutenção e a oferta de recursos tecnológicos sofisticados e de grande apelo visual não garante a identificação do visitante com o site.

Como a oferta de informações, jogos, recursos e aplicativos online é muito grande, o museu que pretende ocupar o espaço precisa se destacar no sentido de estreitar a comunicação com o visitante, oferecendo experiências que diferem da visita à exposição de arte.

Um recurso observado é a tentativa de recriar no espaço virtual os padrões estabelecidos e consagrados para a exibição de obras e de elaboração do discurso curatorial empregado no museu físico. As ferramentas como "visita virtual", "exposição online", "visita 360" tentam replicar na Internet a experiência da recepção estética que tem o visitante do museu, sem levar em conta que o usuário virtual tem como mediador a tela do computador. Esses recursos geralmente causam perdas estéticas e artísticas significativas na construção do discurso sobre Arte.

Outra noção normalmente adotada no Ciberespaço é a de que o visitante pode ser submetido a todo tipo de recurso multimídia e que estimule a participação, causando uma comunicação polifônica e que compromete sua percepção.

Apesar de estar no Ciberespaço, o visitante precisa de tempo e espaço adequados para conhecer as obras e navegar pelo site. Os projetos virtuais devem ser formatados adequadamente a fim de garantir a permanência do usuário por mais tempo nas páginas da instituição. A distribuição dos menus, o acesso aos conteúdos, as cores de fundo da tela, os recursos e ferramentas para a interação online, a versão dos conteúdos em mais de um idioma e a identidade visual do site interferem em sua interpretação e configuram a cenografia digital do projeto.

Além disso, o site tem um papel fundamental na divulgação e exibição da coleção, tanto para o usuário que não tem a oportunidade de conhecer a obra durante uma visita à sede do museu, quanto para a própria instituição que encontra uma alternativa para as 
limitações físicas de suas instalações, exibindo e circulando as obras que não ficam expostas.

Os sites estudados apresentaram diferentes níveis de interação com o usuário. No caso da TATE, a plataforma TATE Online vem desenvolvendo ações que buscam aproximar o público visitante do site e dos valores da própria instituição. Por intermédio da criação de blogs, recursos de vídeo e som, programas destinados a diferentes faixas etárias e que exploram diversas leituras dentro da própria coleção do museu, a TATE busca encontrar o internauta onde quer que ele esteja, seja nos fóruns de discussão, redes sociais ou em programas de pesquisa.

No caso do MAC, o projeto MAC Virtual encontra-se ainda centrado nas ações que tratam o museu de fora para dentro, isto é, que utilizam a plataforma virtual como ferramenta para a divulgação das ações que acontecem dentro da instituição, com poucas possibilidades de interação com o público.

O caminho percorrido até aqui nos mostra que os projetos virtuais das instituições museológicas estudadas serão mais bem sucedidos à medida que considerarem o Ciberespaço como um novo campo de atuação e possibilidades, com características específicas e que difere do espaço consagrado para a exibição de obras.

Dessa forma, as ações que visam à reprodução do espaço expositivo e a simulação da visita virtual tendem a ter menos sucesso do que as que levam em consideração e tem como foco um agente que assume papel fundamental na construção e desenvolvimento do Ciberespaço: o internauta.

O internauta, o público que visita os sites dos museus, precisa encontrar os dispositivos que lhe permitam maior autonomia, participação, pesquisa, possibilidades de novas leituras e associações, de ações que se desenvolvem além das páginas do museu, ou seja, que constituem o que consideramos como características intrínsecas à própria natureza do espaço virtual, a construção colaborativa e compartilhada do conhecimento. Com isso, ele tende a voltar a frequentar as páginas desses sites, constituindo-se assim um novo tipo de público, com perfil e interesses diferentes. É esse público que os museus têm de abarcar.

Ao ingressar no espaço virtual, as instituições têm que levar em consideração que seu potencial de alcance dentro da rede é multiplicado. Por isso, é necessário pensar em estratégias de como se comunicar com o usuário que não está familiarizado com o discurso museológico e com a terminologia própria das Artes Visuais. Aproximar-se desse público é oferecer, além de elementos que contribuam para estimular sua participação e autonomia dentro do site, capacitação para acessar informações, imagens, links e conteúdos que o ajudem a construir e a organizar as referências sobre Artes que ele vai compartilhar. $O$ 
museu precisa ainda diferenciar o espaço digital que ocupa na rede, do espaço físico no qual abriga a coleção, as exposições e demais atividades.

O site não deve querer replicar na Internet a experiência estética e artística de aproximação e leitura da obra de arte. Ele pode sim conter imagens digitalizadas de seu acervo, informações técnicas e históricas sobre os períodos, artistas, enfim, estabelecer referências que aproximem o visitante do projeto político, pedagógico e das diretrizes da instituição, além de procurar estabelecer relações com o usuário, tornando o ambiente virtual mais familiar e contribuindo na criação de um projeto único e integrado entre museu, sociedade e Internet.

Da mesma forma, as publicações analisadas durante a pesquisa constituem-se como um espaço alternativo para o debate crítico e a análise mais profunda e elaborada das ações em torno do sistema das Artes Visuais. Suas atuações, no caso da TATEETC., dão-se em uma escala mais global, e no caso da Contemporânea, são mais ligadas ao debate local, mas ambas sinalizam uma necessidade das instituições assumirem e fomentarem mais diretamente o debate crítico relacionado ao universo das Artes.

Com a perda do espaço para o desenvolvimento de reflexões críticas e estéticas dentro das mídias impressas, a Internet pode ser uma importante ferramenta para viabilizar desse discurso dentro do campo virtual. Nesse caso, seu potencial é elevado e a relevância dos conteúdos abordados merece maior atenção; dadas as possibilidades de difusão da informação, a tradução para mais de um idioma é fundamental.

Observou-se uma preocupação mais direcionada ao espaço digital, em relação à revista Contemporânea. A Contemporânea foi pensada especificamente para atuar no espaço virtual. Ainda assim, e com apenas uma edição publicada, faltam recursos que estimulem a participação do usuário trazendo-o como importante agente na construção do debate sobre o estado e o alcance da Arte hoje.

Além da diferença entre o entendimento do potencial e do uso do espaço virtual observado durante o estudo dos sites das duas instituições, considerou-se de fundamental importância para a manutenção e o desenvolvimento do projeto virtual a gestão compartilhada e o estabelecimento de diretrizes, como foi observado no portal TATE Online, com objetivos a médio e longo prazos, a fim de garantir sua continuidade e independência em relação às ações desenvolvidas.

Pode também ser considerado um fator diferencial da TATE, em relação ao MAC, o patrocínio exclusivo e o suporte de desenvolvimento tecnológico aplicados pela BT no projeto TATE Online, bem como espaço dedicado à doação e parcerias com empresas e instituições, que estimula o relacionamento da instituição com o público e constitui-se como um importante fator de promoção do museu. 
Se os museus são, tradicionalmente, os depositários universais do que consideramos importantes valores e tradições de diversas culturas em diversos tempos, o Ciberespaço inaugura um novo modo de se relacionar com o público e de perceber o espaço e a dimensão do objeto e do fazer artísticos.

Segundo Martin Grossman ${ }^{52}$ :

"O museu de arte hoje é, simultaneamente, uma tradição, um espetáculo, um lugar político, uma promoção social, uma arena para processos de ação sociocultural, uma especulação, uma corporação, uma experiência, bem como alegoria ou metáfora para a explanação, criação e manutenção de outras dimensões de conhecimento. O museu se configura assim como complexidade, grandeza modelada por múltiplas ações."

E nessa nova configuração do museu de arte dos dias atuais, o espaço virtual agrega e distribui as novas dimensões do patrimônio cultural, da atuação das instituições e da participação do público enquanto agente de modificação e atualização do estatuto da obra de arte hoje.

${ }^{52}$ GROSSMANN, Martin. O Museu de Arte Hoje.

Disponível em http://www.forumpermanente.org/.painel/artigos/o_museu_hoje/, acesso em outubro de 2009. 


\section{REFERÊNCIAS BIBLIOGRÁFICAS}

BAUMAN, Zygmunt. O mal-estar da pós-modernidade. Rio de Janeiro: Jorge Zahar, 1998.

BENJAMIN. Walter. Magia e técnica, arte e política: ensaios sobre a literatura e história da cultura. Tradução: Sérgio Paulo Rouanet. São Paulo: Brasiliense, 1994.

BOSI, A. Reflexões sobre a arte. São Paulo: Ática, 2006.

BURKE, Peter. Hibridismo cultural. São Leopoldo: Editora da Universidade do Rio dos Sinos, 2003.

CANCLINI, Nestor Garcia. Leitores, Espectadores e Internautas. São Paulo: lluminuras, 2008.

CAUQUELIN, Anne. Arte Contemporânea: uma introdução. São Paulo: Martins Fontes, 2005.

COELHO, Marcelo. Crítica cultural: teoria e prática. São Paulo: Publifolha, 2006.

DANTO, Arthur. A Transfiguração do Lugar Comum. São Paulo: Cosac \& Naify, 2006.

DEBORD, Guy. A Sociedade do Espetáculo. Rio de Janeiro: Contraponto, 1997.

FLUSSER, Vilem. A Filosofia da Caixa Preta. Rio de Janeiro: Relume-Dumara, 2002.

FREIRE, Cristina. Poéticas do Processo. Arte Conceitual no Museu. São Paulo, Iluminuras, 1999.

GALEFFI, Romano. Fundamentos da Crítica de Arte. Bahia: Centro de Estudos Estéticos, Fundação Cultural do Estado da Bahia, 1981.

GOMBRICH, E. H. A História da Arte. Rio de Janeiro: Zahar, 1978.

GONÇALVES, Lisbeth Rebollo. Entre Cenografias: O Museu e a Exposição de Arte no século XX. São Paulo: Editora da Universidade de São Paulo/Fapesp, 2004.

GONÇALVES, Lisbeth Rebollo, FABRIS, Anatereza (org). Os lugares da crítica de arte. São Paulo: ABCA: Imprensa Oficial do Estado, 2005.

HALL, Stuart. A identidade cultural na pós-modernidade. Rio de Janeiro: DP\&A, 2006.

LÉVY, Pierre. Cibercultura. São Paulo: Ed. 34, 1999.

. As tecnologias da inteligência: o futuro do pensamento na era da informação. Rio de Janeiro: Ed. 34, 1995.

. O que é o Virtual? São Paulo: ED.34, 1996.

LOURENÇO, Maria Cecília França. Museus acolhem moderno. São Paulo: EdUSP, 1999.

MAIA, Rodrigo Filev. Projeto MAC Virtual. São Paulo: POLI - USP, 2003. 
MORAES, Denis (org.). Por uma outra comunicação: mídia, mundialização, cultura e poder. Rio de Janeiro: Record, 2003.

MORRIS, Frances. TATE Modern: The Handbook. London: Tate Publishing, 2010.

O’ DOHERTY, Brian. No Interior do Cubo Branco. São Paulo: Martins Fontes, 2002.

PAREYSON, Luigi. Os Problemas da Estética. São Paulo: Martins Fontes, 2001.

PECCININI, Daisy Valle Machado (coord.). Arte Novos Meios/Multimeios Brasil '70/'80. São Paulo: Fundação Armando Álvares Penteado, 1985.

SANTAELLA, Lucia. Por que as comunicações e as artes estão convergindo? São Paulo: Paulus, 2005.

SEARING, Helen. Art Spaces: The architecture of four Tates. London: Tate Publishing, 2004.

SEVERINO, Antônio Joaquim. Metodologia do trabalho científico. São Paulo: Cortez, 2000.

TATEETC. London, Milbank: Tate Media, 2004 -. Trimestral. ISSN 1743-8853.

Cibergrafia:

BASBAUM, Ricardo. Perspectivas para o museu no século XXI. Disponível em http://www.forumpermanente.org/.painel/artigos/rb_museus/, acesso em setembro de 2010.

BRAIDA, Frederico. Espaços para as artes na era da cultura digital: considerações sobre emergentes espaços públicos (digitais). Disponível em http://www.ufff.br/frederico_braida/files/2011/02/2006_ESPA\%C3\%87OS-PARA-AS-ARTESNA-ERA-DA-CULTURA-DIGITAL.pdf, acesso em setembro de 2010.

BURGOS, Maria de Fátima Borges. Museus Virtuais e a (anti)curadoria: uma aventura em busca do futuro. Disponível em http://www.arte.unb.br/6art/textos/fatima.pdf, acesso em dezembro de 2010.

CARVALHO, Rosane Maria Rocha de. As transformações da relação museu e público: a influência das tecnologias da informação e comunicação no desenvolvimento de um público virtual. Disponível em http://teses.ufrj.br/ECO_D/RosaneMariaRochaDeCarvalho.pdf, acesso em outubro de 2010.

GROSSMANN, Martin. O Museu de Arte Hoje. Disponível em http://www.forumpermanente.org/.painel/artigos/o_museu_hoje/, acesso em outubro de 2009.

HENRIQUES, Rosalis. Museus virtuais e cibermuseus: A Internet e os museus. Lisboa, 2004. Disponível em http://pt.scribd.com/doc/14342377/Museus-Virtuais, acesso em dezembro de 2010.

LOUREIRO, Maria Lucia de Niemeyer Matheus. Webmuseus de arte: aparatos informacionais no ciberespaço. Disponível em http://www.scielo.br/pdf/ci/v33n2/a10v33n2.pdf, acesso em outubro de 2010. 
MARCHI, Ana Carolina de, COSTA, Antonio Carlos da Rocha. CV-MUZAR - Um ambiente de suporte a comunidades virtuais para apoio à aprendizagem em museus. Disponível em http://www.mendeley.com/research/cvmuzar-um-ambiente-suporte-comunidades-virtuaispara-apoio-aprendizagem-em-museus/, acesso em outubro de 2010.

MENEZES, Ebenezer Takuno de. Como as artes habitam a internet: Um estudo sobre a comunicação dos museus virtuais no Brasil e Uruguai. Disponível em http://stoa.usp.br/ebe/files/1/6186/MENEZES_Como_as_artes_habitam_a_internet.pdf, acesso em janeiro de 2010.

MUCHACHO, Rute. O Museu Virtual: as novas tecnologias e a reinvenção do espaço museológico. Disponível em http://www.bocc.ubi.pt/pag/muchacho-rute-museu-virtual-novastecnologias-reinvencao-espaco-museologico.pdf, acesso em dezembro de 2010.

OLIVEIRA, José Cláudio Alves de. Do presencial ao virtual: o museu diante da teoria sistêmica de Niklas Luhmann. O problema da Informação. Disponível em http://dici.ibict.br/archive/00001120/01/dopresencialaovirtual.pdf, acesso em setembro de 2010

.Três cases: os museus no ciberespaço. Disponível em http://www.faculdadesocial.edu.br/dialogospossiveis/artigos/3/05.pdf, acesso em dezembro de 2010.

SOUSA, Cinara Barbosa de. Curadoria em tempos de substâncias imateriais. Disponível em http://www.arte.unb.br/6art/textos/cinara.pdf, acesso em dezembro de 2010.

Tate Modern: The First Five Years. Disponível em http://www.tate.org.uk/modern/tm_5yearspublication.pdf, acesso em novembro de 2009.

THEATER, Lynne. A Museum is a Museum is a Museum... Or Is It?: Exlopre Museology and the Web. Disponível em http://www.archimuse.com/mw98/papers/teather/teather_paper.html, acesso em dezembro de 2010.

Sites consultados:

- www.abca.art.br

- www.archimuse.com

- www.artecapital.net/home.php

- www.artforum.com

- www.artinamericamagazine.com

- www.bienalmercosul.art.br

- www.bienalsaopaulo.globo.com

- www.canalcontemporaneo.art.br

- www.centrepompidou.fr

- www.d13.documenta.de/panorama/

- www.forumpermanente.incubadora.fapesp.br 
- www.fundacaobienal.art.br

- www.icom.museum

- www.itaucultural.org.br

- www.mac.usp.b

- www.malba.org.ar

- www.moma.org

- www.museoreinasofia.es

- www.muva.elpais.com.uy

- www.pensarte.org

- www.revista.agulha.nom.br

- www.sfmoma.org

- www.tate.org.uk

- www.uol.com.br/tropico 


\title{
ANEXOS
}

\begin{abstract}
ANEXO 1
Entrevista com Sérgio Miranda

Entrevista realizada em 11-12-2009 com o jornalista Sérgio Miranda, que faz parte da Equipe Técnica de Imprensa e Divulgação do MAC-USP, feita por Sabrina Popp Marin, mestranda do PGEHA-USP (Programa de Pós-Graduação Interunidades em Estética e História da Arte), na sede do MAC na USP.
\end{abstract}

\section{Como vai funcionar a Revista Contemporânea?}

Ainda não sabemos direito como vai funcionar a revista. Quem fez essa revista para mim, na verdade, foi um grupo de alunos da Metodista, já formados, e no ano passado, em 2008, eles fizeram um trabalho de conclusão de curso sobre o site do MAC. Ficou muito bom, eu gostei bastante do resultado....eles são de Mídias Digitais, então o trabalho deles é desenvolver mesmo a questão técnica e de design daquilo que a gente pede. Foi um trabalho conjunto, de qualquer forma. E eles terminaram esse trabalho, mandaram para mim, e constituíram-se como empresa. Bom, a gente já tinha falado na época, quando se falou no site, eu já tinha contado que achava que teria algum subproduto do site que a gente precisaria desenvolver também. Então, eu acho que você ter um site do MAC, naquele esquema que a gente bolou com eles, um site colaborativo, a gente precisaria pensar em outras ferramentas como blog, como twitter, como RSS para as pessoas receberem notícias, enfim, uma série de outras ferramentas que precisariam ser relacionadas com o site, uma delas a revista digital. Por que a revista digital entraria ai? Porque seria uma compilação de tudo que a gente vai mandar, em vez de ficar mandando cada notícia, como você faz para mandar artigos maiores? Então vamos constituir isso como uma revista. A revista teria um portal específico dentro do próprio site. Quando a Lisbeth pediu uma revista digital, eu os chamei aqui, chamei outras pessoas também, e eles desenvolveram um logotipo, uma proposta bem inicial que foi bem recebida. A Lisbeth gostou muito, mas a gente sempre estava esbarrando na questão, "bom, quando é que vai lançar essa revista?" Em outubro, a Lisbeth me chamou e perguntou o que faltava para lançar a revista. $\mathrm{O}$ que falta é que a gente não tem funcionário aqui no Museu para desenvolver a parte de design digital, e ela pediu para contratar alguém para fazer. Eu nunca quis isso, por quê? Porque tem a experiência do MAC Virtual, de contratar pessoas de fora para fazer e eu não posso, toda vez que a gente precisa, ficar contratando gente diferente para fazer....porque não é para ser uma diferente da outra. Então, eu levantei algumas empresas, inclusive falei com a Lisbeth que a empresa que tivesse o menor preço a gente faria um contrato, assim, pelo menos, você tem um período....mas ai a Lisbeth esta saindo do museu entre março e abril, ela não quis deixar isso amarrado para o próximo diretor, o que de certo modo achei bem responsável da parte dela essa questão de não querer assinar um contrato por um longo período.Bom, esse pessoal da Dim Digital, que é o nome da empresa, apresentou uma proposta, claro, porque eles já tinham tudo pronto, no sentido da ambientação, de já ter conversado, de saber o que a gente queria, de já ter o logotipo feito, então por conta disso eles apresentaram um orçamento mais em conta e a gente então desenvolveu esse primeiro número da revista que está sendo lançado hoje, mas ela já estava no ar, e com a data de novembro porque foi feita em novembro, na verdade, e só a parte técnica esta sendo feita agora. E a perspectiva é que um segundo número seja feito em março, eu acho que a gente teria condições de fazer uma revista mensal, mas eu precisaria, ai sim, de um contrato para poder organizar um esquema de trabalho com toda equipe, interna e externa. Conteúdo a gente tem, mas precisaria de uma organização e uma dedicação mais exclusiva . Por outro 
lado, em janeiro e fevereiro também não acontece nada na USP, em janeiro o reitor toma posse...enfim, eu achei a ideia de lançar em março interessante. $E$ chega o novo diretor em março e abril, e a gente vê se da continuidade, acho uma pena que não continue porque ela teve um resultado técnico muito interessante. Bom, com esse pedido da Lisbeth, e resolvido quem iria fazer, nós conversamos muito sobre a questão do conteúdo com a Professora. Ela sempre falou em ter um conselho para a revista...e eu também acho que esse é o caminho natural que vai acontecer, mas para esse primeiro número, ela determinou uma data para ser lançada, dia 13 de novembro, e nós fizemos um pré-lançamento mostrando a revista no dia 13, mas estamos lançando quase um mês depois por conta de resolver que, o que eram 30 páginas viraram 87, 88. Para esse primeiro número a gente apostou de uma outra forma, vamos fazer com quem quiser colaborar. A gente faz a revista e discute depois em cima dela. Então ela está pronta, foi feita, todos os docentes da casa foram convidados a participar e eu entrei em contato com algumas pessoas de fora para participar também porque um dos princípios da revista, ao mesmo tempo, é dar visibilidade para as coisas que o MAC faz, mas se ficar só nisso fica uma coisa um pouco de panfleto, só falando o que o museu faz, e só pessoas do museu falando. Então, é uma coisa que a gente já comentou, quando se pediu uma revista, mesmo antes da Profa. Lisbeth, quando a Profa. Elza queria uma revista em papel eu sempre mantive o conceito de que pessoas do museu falassem sobre o museu, falassem sobre coisas mais gerais, de fora do museu, e a mesma coisa, pessoas de fora falando sobre o museu ou outras coisas. A ideia é que a revista seja um espaço para essa discussão. Não sei se isso vai continuar assim. Com a revista "no ar" e as pessoas olhando, começa a chover as críticas, o que é normal, e ai nós estabelecemos que vamos convidar imediatamente as docentes da casa para um conselho, e pedir para cada uma, por exemplo, que indique um nome de fora para fazer parte, e eventualmente podemos convidar um artista, um crítico, um jornalista....Agora o que precisa ficar pontuado é que o conselho não pode atravancar a revista, a gente vai discutir uma linha a seguir. Por exemplo, hoje ela tem uma tendência de falar assuntos variados, sobre Arte Contemporânea, não tem um assunto que direciona e amarra todas as coisas, não é uma revista temática, pode até ser assim, mas o conselho pode, com mais propriedade, indicar algumas coisas que seriam importantes constar na revista. Algumas coisas será possível de fazer, outras não. Continua sendo uma revista sem financiamento, portanto, não dá para comprar foto, não dá para pagar artigo, mas dá para fazer muita coisa, você pode ter um convidado internacional, ter mais gente de outros lugares do país participando....a primeira coisa da revista é estabelecer esse conselho, que vai dar mais peso, inclusive acadêmico e institucional, e de credibilidade, enfim, para o universo das Artes, ter esses nomes junto com a gente. Outro passo importantíssimo é que a partir do lançamento do número 1 nós vamos registrá-la no ISBN, e é minha intenção ir atrás de patrocínio para ela, dentro do desenvolvimento que foi feito, pode ter uma marca, pode ter uma forma de fazer com que ela seja uma revista com apoio e que a gente possa então ter uma garantia de uma continuidade, isso talvez não se faça no número 1 , mas talvez no 2 por conta da troca de direção. Outra questão importantíssima é que a ideia é que se desenvolva um portal para essa revista, porque o que faltou para ela agora, e que esta no projeto, é a parte de participação do leitor, de forma mais direta. Então você teria o "comente essa matéria" como num blog, onde o comentário é postado ao lado da página, onde a pessoa que está lendo consegue ver todos os comentários, pode ler, comentar...e daqui há três anos a pessoa ainda pode comentar, porque isso está em um portal, tem acesso ao numero 1, 2, 3...e ela sempre vai ter acesso à participação. Paralelamente, mas eu acho que isso só vem com o financiamento, é a questão da revista ser traduzida para outra língua. Nossa ideia é que ela seja completamente publicada em inglês e espanhol, pelo menos...você está na rede! O português é uma língua bastante acessada, já que os brasileiros são grandes usuários de Internet, mas nessa área de Arte Contemporânea é importante que a gente possa ser lido em outros idiomas.

Acho que essas são as três coisas principais: a questão da instituição do Conselho, a versão para outras línguas e a questão do portal. 


\section{Por que criar uma revista? Para comunicar que tipo de informação além do que o site já publica? Que tipos de atrativo ela teria?}

Bom, se você pensar é uma questão de organização das coisas. O que está colocado no site do museu está lá, sempre e qualquer texto que entrasse poderia ser colocado no site também. Claro que isso estaria organizado de uma forma tal, vamos chamar de uma organização mais passiva, que o público teria que chegar até esses artigos de uma alguma maneira, dentro do site não é tudo que está tão visível. Isso é uma coisa, forma de organização do conteúdo diferente. E a maioria das coisas não tem espaço dentro do site mesmo, falando dos artigos, das coisas mais conceituais. Segundo, que é uma publicação, você registra isso. O texto que você coloca no site não tem um valor para esses institutos....para o currículo lattes. A partir do momento que se tem uma publicação, vai ser registrado, você valoriza quem está escrevendo. No site qualquer coisa pode ser colocada, na revista, espera-se que o seu texto faça parte de uma publicação institucional, teve o aval da instituição, daquele determinado conselho, ou, por exemplo, nesse número, não tem um conselho, mas tem como ver quais foram as outras pessoas que colaboraram pra essa revista. No site do MAC você também está dentro da instituição...até está, mas no site eu posso colocar tudo, na revista você sabe que é só o que foi selecionado. Outra coisa da revista é que, o princípio dela seria, para a Profa.(Lisbeth), garantir que as coisas do MAC cheguem até o público por um publicação própria. De alguma maneira, uma publicação do próprio museu poderia escolher de que forma passar para o público essas informações. Mas não é só isso. Eu acho que o Museu tem um papel importante de liderar essa discussão; Como é que está a Arte Contemporânea? O Mercado da Arte? O que é Arte hoje? O que vale a pena e o que não vale? Isso não está no jornal do dia a dia. Os cadernos de cultura, cada vez mais, são quase que agendas. E a Profa. Lisbeth, especificamente, achou que a possibilidade de fazer uma revista digital poderia levar à publicação de uma revista em papel. O que seria o caminho inverso do que os outros fazem hoje. Eu, sinceramente, acho que isso tem um pouco, principalmente para o meio acadêmico, da valorização do papel, mas como as regras para a valorização dos textos publicados estão mudando, estão valorizando o que é publicado em Internet e em revista digital, talvez essa ideia mude um pouco. Até porque há um diferencial muito grande do que é a revista em papel e do que é a revista digital. A maioria das revistas de museus fizeram um caminho inverso do nosso, eles têm a revista em papel, que nós não temos, e colocaram-na à disposição na Internet, ai não tem muito como ser de outro jeito, porque na revista em papel não tem o vídeo, o som...as pessoas podem imprimir, chegar mais perto, mas não dá para fazer muito mais coisa do que isso. A nossa não é assim. A ideia é usar o que o meio te permite. A gente não usa, por exemplo, música, por questão de direitos, a gente acha que se o cara quer ouvir uma música ele coloca o CD que ele mais gosta de ouvir e pronto. A não ser que a gente vá fazer uma matéria sobre o pessoal de música de câmara que vem aqui se apresentar, então talvez possa ter uma apresentação, mas é um vídeo com som. Acho que isso é um diferencial. Outro é o fato de você ter a opção desse comentário mais participativo, hoje se você quiser comentar uma revista em papel, de Arte, ela é mensal. Você vai escrever hoje, vai ser publicado no próximo número, daqui a um mês, e vai ser repercutida no outro mês, dificilmente isso acontece. Já a revista digital tem toda possibilidade de que isso aconteça. Você vai ler o texto e consegue ver o que as outras pessoas comentaram, e consegue escrever...essa participação do leitor é muito mais efetiva do que na revista impressa. Outro ponto, o acesso à revista. A outra você assina ou compra na banca. Essa, se você gostou, você passa o link para o seu amigo. Inclusive com o portal, vai ter a opção "envie para um amigo". Então esse acesso mais facilitado é um referencial importante também.

\section{E a ideia é que haja um link para a revista dentro do site do MAC?}

Sim, eu vou fazer em três frentes, logo de cara. A primeira, o pessoal que está fazendo e vai distribuir para mim, um e-mail marketing, falando da revista, que eu vou distribuir pro mailing do Museu. Segundo, na página principal do site, eu pretendo colocar a capa da revista. E a 
terceira, é que vou fazer uma nota de imprensa, e divulgar o anúncio de que o museu tem uma revista.

\section{E sobre a reestruturação do site?}

É uma coisa que a gente quer fazer, mas de novo ficamos o período inteiro de gestão da Profa. Lisbeth correndo atrás de financiamento, que é uma coisa que a gente não tem. Agora, nesse final de ano, nós estamos começando o processo para contratar um funcionário que é a figura do analista de comunicações, mas com especialização mais em web, que é a pessoa que vai poder fazer isso. Eu não sei se ele vai ter condições de fazer uma reformulação no site porque é um trabalho grande, mas pelo menos mudar a página e fazer outras coisas, isso ele já vai poder fazer.

\section{Essa primeira página já é diferente?}

Sim, essa primeira já é diferente. O design dela foi feita pela Carla (funcionária da equipe de Técnica de Imprensa e Divulgação) e colocada em $\mathrm{htm} /$ pelo Maurílio, que era um estagiário. E eu tenho alimentado, dentro do que eu consigo fazer. A ideia é ter uma pessoa contratada para isso. Resolve? Não resolve. Melhora muito, muito. Mas para resolver é realmente aguardar o novo diretor para partir para um sistema de refazer a parte básica do site, que é o banco de dados, a ambientação desse banco de dados, que é importantíssimo. Hoje, você tem na sala ao lado o banco de dados do museu que não conversa com o site. Tudo que entra no site em termos de acervo é redigitado, ou seja, pode acontecer erros. Só pra citar uma das ferramentas de acesso dentro do site: o sistema de busca, que não é eficiente. Tem uma série de coisas que são de programação, que a gente precisaria refazer mesmo. Sem falar que não é isso que a gente quer! Por isso que eu acho que a grande coisa é refazer. Todos os especialistas que eu procurei, que olharam o site e analisaram, acharam que é melhor recomeçar do zero. $E$ isso é uma coisa que eu quero, um monte de gente quer, mas custa um dinheiro e precisa ver se o diretor quer. Eu acho que é uma ideia boa que o museu deveria fazer.

Não sei se você já observou isso ou se há alguma expectativa de que o site possa ser um estímulo ao usuário, que está navegando nele, a vir conhecer a sede física do museu? Isso seria levando em conta para a reestruturação do site, para investir nisso?

Eu acho que é, mas é mais do que isso. O que esta precisando, talvez, na cabeça das pessoas que dirigem é isso ser colocado de maneira diferente. Por exemplo, por que o importante é as pessoas virem ao museu? Será que o objetivo do site é fazer as pessoas virem ao museu? Não sei. Eu acho que não. Pode acontecer, mas o objetivo do site é outro. Ele é outro meio, outra forma da pessoa entrar no museu. Bom, mas ai ele não vê a obra de arte, ele vê só a imagem da obra. Mas isso está claro. A pessoa que está navegando sabe disso. Mas por outro lado, o carioca vê, o paranaense vê, o americano vê, o francês vê, só isso já justifica que o site seja construído de uma forma, e é por isso que a gente bate na tecla da derrubada, porque no meu entender o site está construído de uma forma que atende a quem quer entrar e pesquisar parte do acervo, e o sistema de busca não é eficiente para essa pesquisa, mas enfim, tem conteúdo para quem quer pesquisar e quem quer saber o que está acontecendo no museu para poder vir aqui. Agora isso, é 0,001\% das pessoas que buscam Internet. Quem está na Internet tem que entender que é um outro público, que quer as coisas um pouco mais rápidas, e ele quer outra coisa, quer resolver ali mesmo, na Internet. Ah, mas ele não vai ver nunca a exposição do jeito que ela é no museu! Não, não vai. Por isso, inclusive, o que é a gente fez? E isso demonstra bem essa ideia. Quando esse pessoal veio falar comigo sobre essa ideia de fazer um site para o museu, a ideia deles era reproduzir virtualmente este prédio, ou seja, a pessoa passa na porta, entra e vê virtualmente as galerias, etc. E o que eu discuti com eles foi: Por que? Por que o prédio 
que você constrói na Internet é igual ao prédio que está aqui? E isso gerou uma discussão e chegamos à seguinte conclusão: não vai ser mesmo! Nessa proposta de site o visitante entra no saguão, é recebido, a recepcionista fala pra ele: "Bem-vindo, aqui é o MAC. Onde você quer ir agora?" Se quiser ir no Educativo, você entra em uma sala com todos os programas do Educativo. Se quiser ir ao Auditório, tem a coleção de vídeos que você pode assistir, sobre o MAC. Se quiser ver uma exposição, você vai ver uma exposição pensada para o site, não é uma reprodução da exposição que está aqui, em cartaz. Com isso, a gente criaria curadorias para esse espaço, que não necessariamente têm a ver com a exposição que acontece no museu. Pode até ter o mesmo tema, mas é outra exposição, o espaço é diferente, as paredes estão em outros lugares, as esculturas estão em outros lugares, é uma curadoria pensada para aquele espaço. Isso é para te mostrar que a tua pergunta parte de uma ideia que é corrente, que é: Puxa, o site é um meio de comunicação, então ele vai trazer mais gente ao museu? Não sei, se trouxer bom. Mas será que esse é um meio de aferir se o museu é bom ou não? Quantas pessoas vêm ao museu? Você vai oferecer no site coisas que a pessoa não tem quando vem aqui, assim como quando ela vem ao museu ela tem acesso a coisas que ela não terá no site, não adianta. Não substitui a vinda ao museu, então para que você tentar fazer com que seja isso? É claro que o site, mesmo novo, vai anunciar as exposições em cartaz, vai mostrar os textos dessa exposição, as obras, o endereço. Agora, se essa pessoa encontra ferramentas em que ela vivencia esse espaço, você cria o site como um vivenciamento do museu em si.

\section{Falando um pouco do projeto MAC Virtual, o que você acha que funcionou e o que não funcionou?}

O que funcionou, primeiro foi ter deixado um aporte financeiro e de atenção das pessoas do museu ao site, coisa que não tinha tanto. E, principalmente, o desenvolvimento de conteúdo, o museu não tinha as imagens digitalizadas, tinha muito pouca coisa, só se pagava para digitalizar quando ia fazer um catálogo, hoje a gente tem 319 obras cadastradas, com 255 autores. Produziu-se muito texto para cada uma dessas obras, houve uma reformulação dos textos mais antigos, foi realizada a versão para o espanhol e inglês, coisa que o museu não tinha. Na parte de conteúdo houve um investimento muito grande. Os problemas do site MAC Virtual são: um da gestão, porque o museu tinha profissionais envolvidos com o site, tinha gente da informática, web designer, jornalista...nós já estávamos envolvidos com o site e por uma questão de gestão, quando a Profa. Elza assumiu, ela trocou, ela não quis trabalhar com as pessoas que já estavam ali. Eu digo que isso é um problema porque assumiram essas funções pessoas que não tinham uma vivência do museu, não conheciam as pessoas, o que elas podiam fazer e o que não podiam. Então se gastou um esforço muito grande, inclusive financeiro, trazendo pessoas de fora do museu, e ai, quando isso termina, o projeto é de fora do museu, não tem ninguém que sabe mexer na estrutura do site, nem o nosso gerente de informática tem conhecimento, o designer foi todo desenvolvido fora, então houve pouca consulta, eu não fui consultado.

Outro problema é a estrutura do site, que foi entregue ao pessoal da POLI, e hoje tudo o que a gente reclama de estrutura, o sistema de busca que não funciona, a maneira como textos e imagens entram de forma pré-determinada, você não tem como fazer com que o desenho da página se adapte ao texto, mas foi feito desse jeito porque pediram assim, e isso aconteceu porque as pessoas certas não foram consultadas. Então hoje, você vai no sistema de buscas e não acha as coisas. Por exemplo, não consideraram que um autor que tenha um acento no primeiro nome, ao colocar o acento, na ordem alfabética o nome dele fica por último, então você acha que ele não aparece, mas porque ele é o último! Outro exemplo, no campo para você colocar a data da obra, tem obra que não é 1912, é 1912/13, ou "cerca de 1912", sem data, e você não tem isso, o campo é numérico de quatro dígitos, você não pode escrever "sem data", pode deixar em branco, mas para quem olha de fora em branco não quer dizer sem data, pode parecer que esqueceu-se de colocar a data, ou não sabia. São coisas simples, agora a Escola Politécnica da Universidade de São Paulo desenvolveu assim porque foi pedido. Ninguém disse: "Olha, o campo data precisa ter 
espaço para mais caracteres e possibilidades de ter letra". Outro ponto é o design, que não ajuda também, parece que quem fez pensou: "vamos ver tudo que tecnologicamente é moderno e vamos aplicar". Então, usaram várias cores, as imagens passam na horizontal e na vertical, tem uma imagem que fica no fundo, em qualquer página que você vá, você vê no fundo a mesma imagem, isso mostra bem que você tem um conceito completamente oposto do que era o site antes. Quando o site existia, antes do MAC Virtual, o site era administrado pelo Prof. Martin, que aliás foi ele quem propôs o MAC Virtual, mas ele saiu do museu, e a Profa. Elza assumiu. Então não era este que está aí o projeto que o Martin havia proposto. Tanto não é que uma coisa que ele instituiu quando chegou ao site foi que a exposição no site tinha um diálogo com a exposição presencial, não era uma reprodução, ele chamava de uma museografia do espaço digital, então, havia um diálogo entre a web designer e o curador da exposição, hoje você não tem porque tem um padrão, com aquele fundo vermelho, a imagem tem que ter um tamanho predefinido, então eu não consigo usar, por exemplo, de forma adequada uma imagem vertical, porque ela tem um tamanho para entrar naquele espaço.

\section{Nesse projeto do MAC Virtual não foi incorporado nada do que já havia sido feito pelo Martin?}

Não, nada disso. Uma das coisas que a Profa. Lisbeth pediu, e que a gente ainda não conseguiu fazer porque tivemos um problema com o servidor do site antigo, era que quando você clica em "exposições" e você acessa 1995, ela iria para esse site, quando ainda não era o MAC Virtual, entraria a exposição como ela apareceu na época. Esse foi um outro problema do MAC Virtual, ele se preocupou e perdeu muito tempo e muita energia em refazer o que já estava feito. Que é um princípio que eu não concordava.

\section{Na sua opinião, o projeto do MAC Virtual foi pensado para ser um tentativa de extensão do museu?}

Sinceramente, eu não acompanhei nada. Eu não posso te falar o que se pensava fazer, porque era um projeto do Martin, e o que efetivamente foi feito. O que a gente pode é analisar o que foi feito. E o que foi feito mostra uma preocupação de documentação, em arquivo. Nem o fato de ter notícias no site, ou coisa parecida, espaço para imprensa, que nunca foi usado, os eventos, cursos, que anunciam a programação do museu, são todos da mesma estrutura, do mesmo formato. É um site feito para a gente, que trabalha no museu. Quem olha o site não consegue achar as informações. Eu acho que não teve essa preocupação. Então, refez-se o site, não teve nada mais do ponto de vista da discussão do que a mídia permitia. Ai, colocaram ferramentas básicas, como "envie um cartão postal com uma obra do museu", tem umas ferramentas muito rudimentares e pouquíssimo utilizadas.

\section{O MAC Virtual entrou no ar quando?}

O site do MAC entrou no ar em 1995. Depois, em 2002, a Elza assume, e começa o projeto. Como eles começaram a refazer tudo que já estava feito, isso demora cerca de dois anos. Acho que o site entra no ar oficialmente em 2004, e a Lisbeth assume em 2006.

Há o interesse em disponibilizar no site ferramentas de feedback do usuário, espaço para ele comentar notícias, exposições, etc.?

Sim, a ideia é que tudo que seja publicado possa ser comentado. A nossa ideia é, como eu te falei, que quando o cidadão entra no site, ele vê uma recepção, ai ele pode escutar uma breve história de quando foi fundado o museu. Ele pode escolher se quer visitar uma exposição e na parede a gente pensou em algo como aquelas placas de comunicação visual, que indicam os espaços, e dependendo do espaço que ele escolhe, por exemplo, o Auditório, tem todos os vídeos lá para ele assistir. Eventualmente a gente pode começar a 
ter aulas, palestras, entrevistas. E qualquer desses vídeos teria o tópico Comente. Ele pode comentar e ler os comentários feitos por outros visitantes. Em todos os espaços do site haverá esse espaço para o comentário. Acho que é isso que torna o público participante. Estar em um lugar em que ele pode falar. Estando na Internet você tem que estar em um lugar que goste de estar. E ninguém gosta de estar em um lugar em que não acha as coisas que quer, que não pode dar opinião, que é obrigado a escutar e ver as coisas e absorver do jeito que é. Cada um tem a chance de participar, de mostrar que está presente. Essa é uma coisa. Outra coisa é que ele tem a chance de colaborar. Nossa ideia é que o visitante visite o acervo disponível no site, crie sua visual list, as 10 mais, publica, e ai, como ele vai ser cadastrado no site, ele ganha uma página com o perfil dele. E todos podem comentar essa publicação. Ele pode, de repente, postar as obras que ele mesmo faz. E pode receber por email um aviso de que alguém comentou a sua publicação.

\section{E esse cadastramento é para tentar mapear esse usuário?}

Eu acho que tem alguns sentidos legais, porque também a gente não quer que entre qualquer coisa. O museu tem que zelar pelo conteúdo, pelas informações que ele passa, tem que dizer o que é a verdade dele. Mas não precisa cercear as outras pessoas de participarem, falarem, e fazer suas próprias obras. Não é para ser um território livre. Por isso o cadastramento, a necessidade da pessoa ter um e-mail válido. Eu acho fantástico! Não tem museu assim, com esse grau de abertura para as pessoas se sentirem participantes. $E$ por que não tem? Porque os museus acham que seus sites são uma continuidade e que o objetivo é que as pessoas vão até o museu. Além disso, a ideia para o novo site seria cuidar com um pouco de atenção da parte voltada ao público infantil. Seria ter um MAC Criança, para que você tivesse jogos mais orientados, baseados no acervo, didáticos, lúdicos, para várias faixas etárias, fazer uma pesquisa mais adequada com o público usuário. Seria uma preocupação maior com a formação de público. E ele pode nunca vir ao museu, essa é que é a mudança.

\section{Você acha que essas transições de gestão dificultam um pouco o trabalho?}

Não, não vamos dizer que dificulta. Eu acho que quando você tem um projeto consolidado, em que você acredita, ele vai continuar. Por isso minha preocupação é com a revista. A revista teve o primeiro número agora, o segundo deve ser lançado em março de 2010, para ela ter algum fôlego, estar registrada. É um problema da gestão universitária, a cada quatro anos muda, mas os processos, aqueles que valem a pena, tendem a ficar. É claro que pode chegar o novo diretor e achar que a revista deve ser feita de outra forma. Agora o que não pode é cada novo diretor querer imprimir, a cada quatro anos, a sua marca. O diretor muda, mas as pessoas ficam. Então, se você tem um conselho para a revista, por exemplo, é mais improvável que não continue. Se eu faço um site que é do museu, mas que as pessoas participam, o diretor que estiver à frente do museu vai participar daquele site. Você tem que fazer um produto que seja da instituição, e não da direção, seja ele qual for. 
ANEXO 2

FICHA DE ANÁLISE DA CONFIGURAÇÃO DOS SITES DE MUSEUS

Acesso em: OUTUBRO/ 2010

\section{Identificação do Museu}

1.1Museu: TATE

1.2Endereço (URL): http://www.tate.org.uk

1.3Data de criação: 1998

\begin{tabular}{|l|c|c|}
\hline 2. Informações gerais & SIM & NÃO \\
\hline 2.1 Endereço eletrônico & $\mathbf{X}$ & \\
\hline 2.2 Endereço físico & $\mathbf{X}$ & \\
\hline 2.3 Horário de funcionamento & $\mathbf{X}$ & \\
\hline 2.4 Exposições em cartaz & $\mathbf{X}$ & \\
\hline & & \\
\hline 3. Acesso e Pesquisa & & \\
\hline 3.1 Portal de acesso às páginas do museu & $\mathbf{X}$ & \\
\hline 3.2 Apresenta ferramenta de pesquisa & $\mathbf{X}$ & \\
\hline 3.3 Apresenta informações recentes sobre as atividades no museu & $\mathbf{X}$ & \\
\hline 3.4. Apresenta Visita Virtual & $\mathbf{X}$ & \\
\hline 3.4.1 Apresenta planta baixa do museu & $\mathbf{X}$ & \\
\hline 3.5 Indicações para serviços de visita in loco & $\mathbf{X}$ & \\
\hline 3.6 Indicação de atividades e serviços educativos & $\mathbf{X}$ & \\
\hline 3.7 Possibilidade de alteração do idioma & $\mathbf{X}$ & \\
\hline 3.8 Possibilidade de alteração do tamanho do caractere/fonte & & $\mathbf{X}$ \\
\hline 3.9 Permite ouvir o conteúdo do site & $\mathbf{X}$ & \\
\hline 4. Tipos de atividade online & & \\
\hline 4.1 Atividades para crianças & $\mathbf{X}$ & \\
\hline 4.2 Atividades para jovens & $\mathbf{X}$ & \\
\hline 4.3 Atividades para professores & $\mathbf{X}$ & \\
\hline 4.4 Conteúdos de som e vídeo & $\mathbf{X}$ & \\
\hline 4.5 Cursos & $\mathbf{X}$ & \\
\hline 4.6 Acesso ao conteúdo de atividades anteriores & $\mathbf{X}$ & \\
\hline 4.7 Conteúdos de palestras, simpósios, entrevistas, etc. & $\mathbf{X}$ & \\
\hline 5.0 Organização I Apresentação do site & & \\
\hline 5.1 Apresentação das atividades oferecidas & $\mathbf{X}$ & \\
\hline 5.2 Divisão por temas/núcleos & $\mathbf{X}$ & \\
\hline 5.3 Páginas de informação/detalhamento de informações & $\mathbf{X}$ & \\
\hline 5.4 Facilidade de leitura/navegação & $\mathbf{X}$ & \\
\hline 5.5 Identidade visual & $\mathbf{X}$ & \\
\hline 5.6 Cores e padrões definidos em todas as páginas & $\mathbf{X}$ & \\
\hline 5.7 Localização da página em relação ao Portal & $\mathbf{X}$ & \\
\hline 5.8 Cor do texto em relação ao fundo permite a fluidez na leitura & $\mathbf{X}$ & \\
\hline
\end{tabular}




\begin{tabular}{|l|c|c|}
\hline 5.9 Mapa do site & $\mathbf{X}$ & \\
\hline 6.0 Interatividade & & \\
\hline 6.1 Hipertextos & $\mathbf{X}$ & \\
\hline 6.2 Manipular textos ou imagens & $\mathbf{X}$ & \\
\hline 6.3 Inserir informação na atividade (escrever, colorir, cortar, manipular) & $\mathbf{X}$ & \\
\hline 6.4 Comentar textos ou informações & $\mathbf{X}$ & \\
\hline $\begin{array}{l}\text { 6.5 Ferramentas de colaboração com outros serviços da Internet: redes } \\
\text { de relacionamentos, armazenamentos de vídeos e fotos }\end{array}$ & $\mathbf{X}$ & \\
\hline 6.6 Feedback & & \\
\hline 6.7 Curadoria virtual & $\mathbf{X}$ & \\
\hline 6.8 Comunicação com os diversos departamentos do museu & $\mathbf{X}$ & \\
\hline 6.9 Acervo online & $\mathbf{X}$ & \\
\hline 7.0 Recursos & $\mathbf{X}$ & \\
\hline 7.1 Informação sobre as obras do acervo & & \\
\hline 7.2 Informação sobre artistas do acervo & $\mathbf{X}$ & \\
\hline 7.3 Análise estética da obra & $\mathbf{X}$ & \\
\hline 7.4 Contextualização da obra & $\mathbf{X}$ & \\
\hline 7.5 Glossário & $\mathbf{X}$ & \\
\hline 7.6 Informações sobre atividades e departamentos do museu & $\mathbf{X}$ & \\
\hline 7.7 Biblioteca/Publicações & $\mathbf{X}$ & \\
\hline 7.8 Ingressos online & $\mathbf{X}$ & \\
\hline 7.9 Loja online & $\mathbf{X}$ & \\
\hline 8.0 Menu & $\mathbf{X}$ & \\
\hline 8.1 Representação com texto e ícone & & \\
\hline 8.2 Cores de identificação & $\mathbf{X}$ & \\
\hline 8.3 Atividades com menu específico & $\mathbf{X}$ & \\
\hline
\end{tabular}




\section{ANEXO 3}

\section{FICHA DE ANÁLISE DA CONFIGURAÇÃO DOS SITES DE MUSEUS}

\section{Identificação do Museu}

2.1 Museu: MAC USP

2.2 Endereço (URL): hhtp:// www.mac.usp.br

2.3 Data de criação: 2003

\begin{tabular}{|l|c|c|}
\hline 2. Informações gerais & SIM & NÃO \\
\hline 2.1 Endereço eletrônico & $\mathbf{X}$ & \\
\hline 2.2 Endereço físico & $\mathbf{X}$ & \\
\hline 2.3 Horário de funcionamento & $\mathbf{X}$ & \\
\hline 2.4 Exposições em cartaz & $\mathbf{X}$ & \\
\hline 3. Acesso e Pesquisa & & \\
\hline 3.1 Portal de acesso às páginas do museu & $\mathbf{X}$ & \\
\hline 3.2 Apresenta ferramenta de pesquisa & $\mathbf{X}$ & \\
\hline 3.3 Apresenta informações recentes sobre as atividades no museu & $\mathbf{X}$ & \\
\hline 3.4 Apresenta Visita Virtual & $\mathbf{X}$ & \\
\hline 3.4.1 Apresenta planta baixa do museu & & $\mathbf{X}$ \\
\hline 3.5 Indicações para serviços de visita in loco & $\mathbf{X}$ & \\
\hline 3.6 Indicação de atividades e serviços educativos & $\mathbf{X}$ & \\
\hline 3.7 Possibilidade de alteração do idioma & $\mathbf{X}$ & \\
\hline 3.8 Possibilidade de alteração do tamanho do caractere & & $\mathbf{X}$ \\
\hline 3.9 Permite ouvir o conteúdo do site & & $\mathbf{X}$ \\
\hline 4. Tipos de atividade online & & \\
\hline 4.1 Atividades para crianças & $\mathbf{X}$ & \\
\hline 4.2 Atividades para jovens & & \\
\hline 4.3 Atividades para professores & & $\mathbf{X}$ \\
\hline 4.4 Conteúdos de som e vídeo & $\mathbf{X}$ & \\
\hline 4.5 Cursos & & $\mathbf{X}$ \\
\hline 4.6 Acesso ao conteúdo de atividades anteriores & & $\mathbf{X}$ \\
\hline 4.7 Conteúdos de palestras, simpósios, entrevistas, etc. & & $\mathbf{X}$ \\
\hline 5.0 Organização I Apresentação do site & & \\
\hline 5.1 Apresentação das atividades oferecidas & $\mathbf{X}$ & \\
\hline 5.2 Divisão por temas/núcleos & $\mathbf{X}$ & \\
\hline 5.3 Páginas de informação/detalhamento de informações & $\mathbf{X}$ & \\
\hline 5.4 Facilidade de leitura/navegação & $\mathbf{X}$ & \\
\hline 5.5 Identidade visual & $\mathbf{X}$ & \\
\hline 5.6 Cores e padrões definidos em todas as páginas & & \\
\hline 5.7 Localização da página em relação ao Portal & & \\
\hline 5.8 Cor do texto em relação ao fundo permite a fluidez na leitura & \\
\hline 5.9 Mapa do site & & \\
\hline 6.0 Interatividade & & \\
\hline
\end{tabular}




\begin{tabular}{|l|c|c|}
\hline 6.1 Hipertextos & & $\mathbf{X}$ \\
\hline 6.2 Manipular textos ou imagens & & $\mathbf{X}$ \\
\hline 6.3 Inserir informação na atividade (escrever, colorir, cortar, manipular) & & $\mathbf{X}$ \\
\hline 6.4 Comentar textos ou informações & & $\mathbf{X}$ \\
\hline $\begin{array}{l}\text { 6.5 Ferramentas de colaboração com outros serviços da Internet: redes } \\
\text { de relacionamentos, armazenamentos de vídeos e fotos }\end{array}$ & & $\mathbf{X}$ \\
\hline 6.6 Feedback & & $\mathbf{X}$ \\
\hline 6.7 Curadoria virtual & & $\mathbf{X}$ \\
\hline 6.8 Comunicação com os diversos departamentos do museu & $\mathbf{X}$ & \\
\hline 6.9 Acervo online & $\mathbf{X}$ & \\
\hline 7.0 Recursos & & \\
\hline 7.1 Informação sobre as obras do acervo & $\mathbf{X}$ & \\
\hline 7.2 Informação sobre artistas do acervo & $\mathbf{X}$ & \\
\hline 7.3 Análise estética da obra & $\mathbf{X}$ & \\
\hline 7.4 Contextualização da obra & $\mathbf{X}$ & \\
\hline 7.5 Glossário & $\mathbf{X}$ & \\
\hline 7.6 Informações sobre atividades e departamentos do museu & $\mathbf{X}$ & \\
\hline 7.7 Biblioteca/Publicações & $\mathbf{X}$ & \\
\hline 7.8 Ingressos online & & $\mathbf{X}$ \\
\hline 7.9 Loja online & & $\mathbf{X}$ \\
\hline 8.0 Menu & & \\
\hline 8.1 Representação com texto e ícone & $\mathbf{X}$ & \\
\hline 8.2 Cores de identificação & & $\mathbf{X}$ \\
\hline 8.3 Atividades com menu específico & & $\mathbf{X}$ \\
\hline
\end{tabular}

